\title{
Immunocytochemical studies in colorectal carcinoma
}

Citation for published version (APA):

Arends, J. W. (1984). Immunocytochemical studies in colorectal carcinoma. [Doctoral Thesis, Maastricht University]. Rijksuniversiteit Limburg. https://doi.org/10.26481/dis.19840517ja

Document status and date:

Published: 01/01/1984

DOI:

10.26481/dis.19840517ja

Document Version:

Publisher's PDF, also known as Version of record

\section{Please check the document version of this publication:}

- A submitted manuscript is the version of the article upon submission and before peer-review. There can be important differences between the submitted version and the official published version of record.

People interested in the research are advised to contact the author for the final version of the publication, or visit the DOI to the publisher's website.

- The final author version and the galley proof are versions of the publication after peer review.

- The final published version features the final layout of the paper including the volume, issue and page numbers.

Link to publication

\footnotetext{
General rights rights.

- You may freely distribute the URL identifying the publication in the public portal. please follow below link for the End User Agreement:

www.umlib.nl/taverne-license

Take down policy

If you believe that this document breaches copyright please contact us at:

repository@maastrichtuniversity.nl

providing details and we will investigate your claim.
}

Copyright and moral rights for the publications made accessible in the public portal are retained by the authors and/or other copyright owners and it is a condition of accessing publications that users recognise and abide by the legal requirements associated with these

- Users may download and print one copy of any publication from the public portal for the purpose of private study or research.

- You may not further distribute the material or use it for any profit-making activity or commercial gain

If the publication is distributed under the terms of Article $25 \mathrm{fa}$ of the Dutch Copyright Act, indicated by the "Taverne" license above, 
IMMUNOCYTOCHEMICAL STUDIES IN COLORECTAL CARCINOMA

Jan Willem Arends 
Drsk: Drukkerij Groenevelt/Landgraaf 


\section{Immunocytochemical Studies in Colorectal Carcinoma}

Proefschrift ter verkrijging van de graad van Doctor in de Geneeskunde aan de Rijksuniversiteit Limburg te Maastricht op gezag wan de Rector Magnificus Prof.Dr. H.C. Hemker volgens het besluit van het College van Dekanen in het openbaar te verdedigen in de Aula van de Universiteit op

donderdag 1.7 mei 1984

des namiddags te 16.00 uur

door

Jan Willem Arends

geboren te Groningen. 
Promotores: Prof.Dr. G.J.V. Swaen

Prof.Dr. F.T. Bosman

Referenten: Prof.Dr. J.M. Greep

Prof. P. Isaacson, M.R.C. Path. 
To the memory of my father 
1.1.

1. 2 .

1.3.

1. 4.

1.4 .1 .

1.4 .2 .

1.4 .3$.

1.4 .4 .

1.5.

1.5.1.

1.5 .2$.

1.6.

1.7 .

1.8.

1.9 .

Chapter II

2.1.

2.2.

2.3.

2.3 .1 .

2. 3.2.

2.3 .3$.

2. 4 .

2.4 .1 .

2.4.2.

2.4 .3 .

2.5 .

2.6.
General value of antigen expression in tumours Clinicopathological value of antigen expression in tumours

Nature of tumour antigens

Methods for tumour antigen detection in tissue Conventional histochemical staining methods Enzymehistochemistry

Immunocy tochem istry

Lectin affinity reactions

Classification of tumour antigens in colorectal cancer

Tumour - associated antigens.

a. Tumour - associated nuclear antigens

b. Oncofetal antigens

c. Other tumour - associated antigens

Tissue - antigens

a. Cell constituents -cytoplasmic antigens

- membrane antigens.

b. Cell products

- goblet cell antigens

- collumar cell antigen

-endocrine cell antigens

-Paneth cell antigens

Antigen-specificity in colorectal carcinomas Phenotypic heterogeneity of antigen expression Design of the study

References

DISTRIBUTION OF MONOCLONAL ANTIBODY-DEFINED MONOSIALOGANGLIOSIDE IN NORMAL AND CANCEROUS HUMAN TISSUES: AN IMMUNOPEROXIDASE STUDY.

Summary

Introduction

Material and methods

Monoclona l. antibody

Tissues

Immunocy tochemistry

Results

Adenocarcinomas

Adult glandular and mucosal epithelia

Petal intestinal tissue 
CARCINOMA IN RELAIION TO STAGE, HISTOPATHOLOGY AND DNA ELOW CYTOMETRY.

3.1.

3.2 .

3.3 .

3.3 .1 .

$3.3 \cdot 2$.

3.3 .3$.

3.3 .4 .

3.3 .5$.

3.3 .6 .

3.3 .7 .

3.3 .8$.

3.4 .

$3,4, \mathbb{1}$.

3.4 .2 .

3.4 .3 .

3.4 .4 .

3.4 .5 .

3.5 .

3.6 .

\section{Chapter IV}

4.1 .

4.2 .

4.3 .

4.3 .1$.

4.3 .2 .

4. 3.3.

4.3 .4$.

4. 4.

4.4 .1 .

4.4 .2 .

4.4 .3 .

4.4.4.

4.5 .

4.6.
Summary

Introduction

Material and methods

Tissues

Classification of specimens

Localization

Staging

Grading

Immunohis tochemistry

scoring of immunoreactivity

Elow cytometry

Results

GICA immunoreactivity in colorectal carcinoma

GICA expression and localization

GICA expression and staging

GICA expression and grading

GICA expression and flow cytometry

Discussion

References

GASTROINTESTINAL CANCER ASSOCTATED ANTIGEN (GICA) IMMUNOREACTIVITY IN COLORECTAL CARCINOMA IN RELATION TO PATIENT SURVIVAL.

Summary

Introduction

Material and methods

Patients and clinical follow-up data

Staging and grading procedures

Immunocytochemistry

Statistical analysis

Results

Validity of the GICA immunoreactivity score General pattern of GICA immunoreactivity

GICA immunoreactivity in relation to patient survival

Stratification for stage and grade

Dîscussion

References
62

63

63

63

63

64

64

64

64

64

68

68

70

72 
"THE VALUE DE SECRETORY COMPONENT (SC) IMMUMO REACTIVITY IN DIAGNOSIS AND PROGNOSIS OF COLO RECTAL CARCINOMAS

5.1.

5.2.

5.3.

5.3 .1$.

5.3 .2 .

5.3 .3$.

5.3 .4$.

5.3 .5 .

5.3.6.

5.4.

5.4 .1$.

5.4 .2 .

5.4 .3 .

5.4 .4 .

5.5 .

5.6 .
Summary

Introduction

Materlal and methods

Staging

Grading

Follow-up data

Irumunocy tochenistry

Scoring of immunoreactivity

statistical analysis

Results

Validity of staging and grading procedures

General distribution of SC immunoreactivity

SC immunoreactivity and stage/grade

$\mathrm{SC}$ immunoreactivity and patient surwival

Discussion
References

TUMOUR CELL HETERDGENEITY IN PRIMARY AND ME TASTATIC COLORECTAL CARCINOMA.

\section{Summary}

Introduction

Material and methods

Material

Nature of antibodies

Irmunocy tochem istry

scoring of immunoreactivity

Results

General characteristics of antigen localization and mode of expression

Characteristics of antigen expression in prima ry tumours and regional lymphnode metastases Characteristics of antigen expression in prima ry tumours and distant and/or hematogenous metastases

Discussion

References 
7.1 .

7.2

7.3.

7.3 .1

7.3 .2 .

7.4.

7.5.

7.6 .
Intraduction

Summary of the results of the study

Possible alleviating approaches to limiting

aspects of antigen expression

Antigen-specificity

Phenotypic heterogeneity

Future perspectives of antigen expression stu dies in cell-origin-related classification of colorectal carcinomas

Concluding remark - value of "developmental" antigens

References

SAMENVATTING

SUMMARY

ACKNOWLEDGMENTS

CURR ICULUM VITAE
116

100

100

102

102

103

1.04

1.07

1.09

111

114

118 



\section{INTRODUCTION.}

In this chapter a review of the literature on the general and clinicopathological aspects, nature and methods for the detection of antigens in neoplastic tissue is presented. Subsequently, a classification of tumour antigens is proposed and the most relevant antigens with regard to colorectal carcinomas are described.

Both the possibilities of tissue antigen detection in respect of diagnosis, classification and assessment of prognosis in colorectal cancers and the limitations inherent to the approach in terms of antigen - specificity and phenotypic heterogeneity of antigen expression are discussed.

This chapter is concluded with a description of the design of the present study.

1.1. General value of tumour - antigen expression

Because of the perspectives inherent to the detection of compounds specific for or associated with neoplasia in body fluids and tissues the study of tumour-antigens has aroused great interest in many disciplines of medical science during the past decade.

The option for the clinical oncologist mainly lies in the measurement of tumour - antigens in body fluids for early diagnosis and the monitoring of the results of tumour therapy. In addition the perspectives for the ability to localize and possibly treat tumours through immunotargeting procedures are challenging.

Identification and histotopographic localization of substances, such as tumour - antigens, add additional criteria to those currently employed in histopathology for classification and assessment of histological grade in carcinomas.

Study of antigen expression at the cellular level is of value for the cell biologist to relate alterations in antigen display to the process of cellular differentiation and the mechanisms involved in the development of abberant behaviour of neoplastic cells.

1.2. Clinicopathological valwe of tumour - antigen

\section{expression}

For cilinicopathological purposes the study of antigen expresion in tissues is most relevant in cegard of:

a. The characterization and classification of primarytumours and metastases of unknown origin.

An excellent example of the value, which detection of antigens accurring in a limited number of tissues may have for tumour classification, is the immunohistochemical detection of prostate specific acid phosphatase. Due to the allmost exclusive presence of this antigen in prostatic glandular epithelium and derivative neoplasms adenocarcinomas can be 
characterized and metastatic lesions can be demonstrated as of prostatic origin (Jöbsis et al., 1978).

b. The asesment of the type and degree of differentiation of tumours (assessment of prognosis)

The value of deternination of antigen display in morphologically identical neoplasms for defining subgroups with a distinct biological and clinical behaviour is exemplified in acute 1 ymphatic leukemia (ALL). According to the expression of $B$ and $T$ cell antigens $A L L$ has been separated into at least three groups: non $B$ - non $T$ cell ALL, $T$ cell $A L L$ and $B$ cll AL, ach with a distinct clinical behaviour, response to therapeutic regimes and prognosis lJondal et al., 1973* Tsukimoto et a1., 1976; Belponme et al., 1977; Brouet et a1., 1978; Sallen et al., 1980; Greaves, 1981..

1.3. Mature of tumour - antigens

Since the early days of Ehrlich (1906) it has been postulated, that cells in the process of neoplastic transformation acquire tumour-specific antigens capable to elicite immune reactions, which might play a role in the defence of the organism against the development of neoplasia. The first conclusive evidence for the existence of such antigens in animals was obtained by Foley (1953), who demonstrated that methyl cholantrene - induced tumours transplanted in syngeneic mice could be rejected. In the following years similar observations were made in various wirally and chemically induced tumour systems in experimental animals (see for review Baldwin, 1973).

Evidence for the existence of tumour-specific antigens in humans, however, remained circumstantial for various reasons. Firstly, due to the ethical preclusion of in vivo studies, demonstration of cellular and/or humoral immune responses in cancer patients against their tumour only relied on elaborate in vitro studies, in which autologous tumour cells seldom could be used. It, therefore, remained impossible to definitely rule out the possibility, that the immune reactions observed were directed against alloantigens present in the tumour - test - tissue used in these experiments. Secondly, the identification of tumour-specific antigens by immunizing with human cancer cells or products of cancer cells has been frustrated by the strong immunogenic challenge by normal human tissue antigens present on the immunizing agents. This problem necessitated extensive absorption of xenoantisera with normal human tissues. During this process, however, trace amounts of tumour-specilic antibodies could have been lost as well.

The bybridoma technique introduced by kohler and Milstein (1975), which enables the generation of unlimited amounts of monospecific antibodies and also potentially allows for the selection of antibodies directed against weak immunogens, has created the expectation that the problem, whether or not antigens unique to a given tumour and not expressed in other tumours or normal tissues occur in the human situation, would be answered. 
This expectation, however, as yet has not been substantiated and so far experimental data suggest, that in respect of antigen expression, neoplastic tissue only differs from normal tissue in a quantitative, but not in qualitative sense. In view of this situation it might be more appropriate to speak of tumour - associated antigens than of tumour - specific antigens. Many of these antigens, such as carcinoembryonic antigen, have been found predominantiy in neoplastic cells and, although in almost all cases extensive studies demonstrated their expression in non-neoplastic cells as well, we will refer to these antigens as "tumourassociated" " Other antigens accur in normal cells, but have been studied in neoplastic cells, because they relate to particular lines of differentiation (such as the intermediate filament proteins) or are specific for a single cell type (such as thyroglobulin or prostate specific acid phosphatiase) and will be referred to as "tissue-antigens".

Although certain tumour cell products or constituents are detected by other than immunological methods, the designation tumour "antigens" in general appears to be acceptable in view of the fact that the majority of tumour-associated macromolecules are studied through their detection by specific antibodies.

Since this study concentrates on colorectal carcinomas, in the following paragraphs the discussiom on tumour-antigens will be malnly restricted to antigens of relevance for tumours of the gastrointestinal tract and more especially the large intestine.

1.4. Methods for the detection of tumour-antigens in tissue

1.4.1. Conventional histochemical staining methods, which allow the visualization and localization of a category of substances rather than one chemically defined molecule have been employed by histopathologists since a long time. For tissues of gastrointestinal tract derivation histochemical reactions on mucosubstances are of special. interest. Neutral mucins, sialomucins and sulphomucins can be visualized with the diastase-periodic acid-schiff, the alcian-blue at pH 2.5 and high iron-diamine reactions respectively (Pearse, 1968; Spicer, 1965). A number of refined stains has been developed, which often permit distinction of different mucins in the same section (Filipe, 1979; Culling et al., 1976).

Neuroendocrine cells in normal and neoplastic gastrointestinal mucosa can be detected with silver impregnation methods, such as the argentaffin and argyrophil staining reactions (Sevier and Munger, 1965; Grimelius, 1968).

1.4.2. Enzymehistochemistry, which is based on the interaction of a given enzyme with a given substrate allows specific identification of tissue enaymes (wilighagen, 1970). Due to the fact that most enzymes do not appear to be organ or cell specific, its practical use, however, is limited and this also applies to the gastrointestinal tract. 
1.4.3. Immunocytochemistry nowadays is by far the most inportant method to identify celi products or constituents. The technigue basically relies on the specific interaction between tigsue antigens and corresponding antibodies, which can be visualized with various flucrochromes (Coons et al." 1941 or enzyme labels (Nakane et a 1." 1966; Avrameas, $1967)$. In the past 15 years numerous innovations and nodilcations of the original standard methods have been developed, which are sumarized in many reviews (Taylor, 1978; Falini and Taylor, 1983: Bosman, 1983). Most of these a 1terations are aimed at improving the specificity and sensitulty of the technique.

specificity problems may occur at the level of the antibody used and/or the method erployed. Antibody- specificity is one of the most important conditions for reliable immunocytochemistry and should be ascertained by adequate control procedures. As a first step affinity purification of antisera with the purified antigen is mandatory. The specificity of the antiserum thus obtained should be further checked with immunodiffusion and immunoelectrophoresis or with more sensitive fadio- or enzyme immunoassays. The hybeldoma technique (kohler and Milstein, 1975), which enables the generation of unlimited amounts of monoclonal and therefore monospecific antibodies, appears to be a major improvement in artibody-specificity, but the supreme specificity of these antibodies ma in itself be a problem, due to the occurrence of their target-epitope on different non-chemically related macromolecules (Diamond et al., 1981; Dulbecco et a1. 1981). Method specificity should be determined by adequate tissue controles involving the inclusion of positive reference tissues, omission and replacement of the specific antibody by non-immume serum and blocking with purified antigen (Dellelis et al., 1979).

The sensitivity of the technique has been enhanced by procedures to increase the number of enzym-labels per antigen binding site (Ordronneau et a I., 1980) and also by intensifying the reaction product obtained ith a given amount of enzymatic activity (Gallyas et al., I982: Strauss, 1932). In respect of routinely processed formalin fixed and paraffin embedded tissues it should be realized that denaturation of antigenic structures due to tissue preparation procedures might compromise the sensitivity of the reaction. The extent of antigenic preservation appears to be variable for different antigens and largely depends on the fixative employed (Curran et al., 1980). Proteolytic digestion of tissue sections with e.g. trypsine prior to incubation with antibody may enhance sensitivity by "umasking" antigenic sites and allow detection of many antigens after routine fixtion with 4 neutral buffered formalin (Mepham et al, $1979)$.

1.4.4. Lectin-affinity reactions have been used to explore the occurrence of carbohydrates and glycoproteins on cell membranes in tissue sections (stoward et a 1., 1980; Walker, 
1982; West et a1., 1982). Lectins bind glycoproteins through their affinity for specific sugar sequences. Many different lectins are known, each with specificity for a particular sugar sequence (for review see Gold and Balding 1975). staining of tissue with lectins can be performed either ith direct lectin fluorochrome conjugates or using immunological procedures involving the application of a lectin antibody in a direct or indirect fluorescence test after prior incubation with the lectin (Leathem and Atkins, 1983 ). On parafin sections lectin binding often appears to be attenuated due to denaturation of proteins with carbohydrate sequestration during the process of fixation and embedding Prior trypsinization and/or neuraminidase treatment of the paraffin sections may considerably increase the intensity of the lectin binding reaction, but the pattern of distribution of the lectin binding carbohydrates may be altered ater these procedures (Leathem and Atkins, 1983). Therefore lectin affinity reactions preferably should be performed in mildly fixed frozen tissue sections.

\subsection{Classification of tumour-antigens}

As indicated in paragraph 1.3. We propose a subdivision of tumour-antigens into tumour-associated antigens and tissue-antigens.

Although most of the tumour-associated antigens also occur in normal tissue components, the designation is chosen to indicate that antigens of this nature are predominantiy found in neoplasms or are somehow related to the neoplastic process.

Tíssue antigens, in contrast, comprise normal cell constituents or cell products. which may have relevance for the study of tumour tissue.

of course it should be realized that the nature of certain antigens does not allow an unambiguous classification into one of these two main categories, so that the subdivision remains rather arbitrary. For example, some mucoproteins defined by conventional antibodies have been tested mainly in tumours and/or are considered to be of oncofetal nature. Nevertheless, they will be discussed in comection with the mucins detected by conventional histochemical reactions in the paragraph on goblet cell products.

In general, however, this subdivision seems to be rather logical and allows the classification, even of tumour antigens of ill-defined nature, in a satistactory scheme in which relatively Eew overlaps, omissions or misplacements occur.

\subsubsection{Tumour-associated antigens}

Tumour-associated antigens may be distinguished into three sub-groups: nuclear, oncofetal and other antigens.

a. Tumour-associated nuclear antigens

In the area of research focussed on alteration of nuclear 
(chronatin) antigens in neoplasms caused by environmental carcinogenic agents or oncogenic viruses a lot of experimental dat has been collected by molecular biologists. which indicates the tremendous impact of these studies on our understanding of the genetic mechanisms involved in malignant transformation and also provides challenging perspectives for new approaches in the classification and treatrent of neoplasia.

Tumour-associated nuclear antigens which seem to appear at an early stage of malignant transformation, have beem demonstrated in 1-2-dimethylhydrazine-induced colonic tumours in rats (Chíu et a l., 1980; Gabryelak, I981) and the human colonic adenocarcinoma cell lines $H^{-}-29$ and Lovo (Duhl et al., 1982). The existence of virally induced tumour-associated nuclear antigens has not been reported in respect of colonic carcinoma.

Recent studies using gene-transfer methodology (Weinberg, 1981) have shown the existence of genes activated in human tumours, which confer the properties of malignancy (stik et al." 1979; Cooper, 1980). These genes, known as cellular transforming genes, or oncogenes, have been demonstrated in cell Iines and cell preparations of surgically removed human cancers amongst which colorectal adenacarcinomas (Pulciani et al., 1982). The DNA sequence of mast oncogenes now isolated from human solid tumours shows a remarkable homology to genes carried by one family of retroviruses (Pulciani et al., 1982; Santos et a 1., 1982; Parada, 1982; Shimizu et a 1., 1983). Other human transforming genes, particularly those from leukemias and lymphomas are known to occur due to chromosal translocations (Rechavi et al., 1982; Taub et a 1., 1982; Dalla-Favera et a1., 1982 ; De Klein et a.." 1982) and have not been matched to any of the human viral oncogenes. Therefore experimental data sofar suggest that activation of an oncogene can be due to mutation of a normal gene or chromosal translocation of a gene, by the virtue of wich this gene is more actively transcribed. Thus, the proteins encoded by transforming genes may consist of real tumour - neoantigens, but also of normal cell compounds, which are produced in quantities different from those in normal cells. Identification and manipulation of the transcription products of oncogenes may be expected to generate new impulses in all fields of cancer research, but the clinicopathological implications as yet seem to be remote.

b. Oncofetal antigens

Carcinoembryonic antigen (CEA), the protoye of colorectal carcinoma-associated antigens, originally was thought to be of oncofetal nature (Gold and Freeman, 1965; Gold and Freeman, 1965). Although its presence has now been detected in protein synthetic organelies and in a polar pattern at the microvili of the apical plasmamembrane of normal columnar and goblet cells of colonic epithelium (Ahnen et al., 1982), the antigen will be discussed in this paragraph on 
oncofetal antigens because of its strong historical association with antigens of this nature.

CEA has been most extensively studied and a number of reviews on the characteristics of the antigen are arailable, of which those of Rogers (1976 and 1983) present a complete and up to date description. In this paragraph information on CEA is restricted to its application at the tissue level and to some recent developments concerning the generation of CEA reactive monoclonal antibodies.

Due to its presence in normal colonic mucosa (Khoo et a1., 1973; Goldenberg et a1., 1975; fuitricet al., 1976; Isaacson and Judd, 1978; O'Brien et al., 1981), as well as carcinonas of e.g. respiratory (Pascal et al.., 1977; Hill et $a 1 ., 1979$ ) and genitourinary tract origin (Marchand et a1., 1975; Heald et al., 1979; van Nage11 jr., 1979; Shousha and Lyssiotis, 1978; Shevchuck et al, 1981) the value of CEA in colorectal carcinoma has been reduced to its serum assessment for monitoring of colorectal cancer patients (Goldenberg et a1., 1981; Persijn and Hart, 1981 ).

The lack of tumour specificity of CEA has been attributed to heterogeneity of the molecule as determined after various purification methods (Fuks et a1., 1974; Vrba et a1., 1975 ) and crossreaction of polyclonal antisera with other antigenically related molecules (von kleist et a 1 ." 1972; Mach and Pusztaszeri, 1972; Burtin et al. 1973; Swenberg et a 1., 1979; Kuroki et a 1., 1982). Efforts to improve the specificity of CEA detection by more elaborate methods of purification or absorption of antisera with CEA-crossreacting agents have not $y$ ielded antisera with a more restricted reaction pattern. Recently, however, a rapid and reproducible immumabsorption technique resulting in a monospecific anti CEA serum applicable in histopathology has been described (Nap et al., 1983).

Monoclonal antibodies should offer a tool to define the CEA molecule and associated molecular forms more precisely. Antibodies of this variety therefore should provide means to test the possibility whether different forms of CEA are expressed in neoplastic and normal tissue or in different conditions of disease (Rogers, 1976). In the past few years several groups of workers have reported on the generation of monoclonal antibodies reactive with CEA (Mitchell, 1980: Accolla et a 1." 1980; Kupchik et al." I981; Rogers, 1981; Buchegger et a1.. 1982; Prinus et al., 1983a), but few reports deal with their reaction pattern at the tissue level. Monoclonal antibodies have been claimed to be superior to conventional antisera in immunoperoxidase stalning of CEA, due to their high affinity resulting in neglectable backgroumd staining (Lindgren et al., 1982). Primus et a 1 ., $1983 \mathrm{~b}$ ) described an anti CEA monoclonal antibody lacking nonspecific cross reacting antigen (NCA) reactivity, which reacted with only $30 \%$ of colorectal carcinomas and therefore may recognize a unique determinant expressed on a subpopum lation of CEA molecules. Its staining of normal colonic mucosa was apparent, but weak. Imai et al. (1984) studied 
three monoclonal antibodies reactive with CEA or CEA related molecules, which reacted with the majority of colon carcinomas and not with normal or fetal colonic mucosa. Wagener et a 1. (1983) reported on a monoclonal antibody, which demonstrated an almost exclusive specificity for a tumourassociated antigenic determinant on the CEA molecule and showed no or maxginal crossreaction with biliary glycoprotein (BGP) and NCA respectively. Therefore, there are indications that CEA reactive monoclonal antibodies may probe into the problem of heterogeneity of the CEA molecule and associated crossreacting antigens more exactly, but before a clear picture about the precise state of purported specific CEA moieties in respect of different organs and conditions of disease is to be given, a lot more of documentary work is to be done.

In recent years much attention has been focussed on the development of techniques to detect and localize malignant neoplasms by means of radiolabeled antibodies in combination with scintigraphic scanning methods. Due to its uniform expression in the majority of tumour cells of both primary and metastatic colorectal tumours most immunotargeting procedures so far have used CEA as target-antigen despite its distribution in nomal intestinal mucosa and its release into body Eluids Goldenberg et a $1 .(1980,1982)$ have reported with optimism about the perspectives of immunotargeting procedures using anti CEA antibodies as targeting vehicles in transplant tumour bearing nude mice and colorectal cancer patients, whereas Mach and co-workers (Mach et al., 1981; Bercher et al.. 1982) employing both conventional and monoclonal CEA reactive antibodies in the same experimental settings seem to be more cautious in their expectations. Others (Hedin et al., 1982) have also reported about the use of monoclonal anti CEA antibodies in immunotargeting.

The presence of alpha-fetoprotein (AFP) in about half of colonic carcinomas has been mentioned in one publication, but no details about its exact distribution were given (Skinner and whitehead, 1981). Oncofetal antigen-1 (OFA-1) has been reported to occur in $15 \%$ of colorectal carcinomas Rees et a1., 1981). Other products associated with fetal tissues demoristrated in colorectal cancers include human chorionic gonadotropin (HCG) "Gailani, 1976; Buckley and Fox, 1979) and human placental lactogen (HPL) (Skinner and Whitehead, 1981). A Eucosyl antigen expressed in colon adenocarcinoma and embryonal carcinoma cells has been recently reported (Miyauchi et al., I982).

\section{c. Other tumour-associated antigens}

some antigens, which have been studied in connection with colorectal cancer mainly or exclusively at the serological level are listed below and will not be discussed in greater detail, because of lack of experimental data concerning their expression in colorectal carcinoma tissue. 
zinc glycinate marker

Tennessee antigen

$2 \mathrm{GM}$

Terna gen

B2 microglobuline

Galactosyltransferase II

Membrane tissue antigen

Basic fetoprotein
$B 2 M$

GI II

MTA

BEP
Pusztazeri et al.. 1976

Potter et a . 1976 Gray et a1. 1982a. b: Pentycross et al. , 1982

Staab et al., 1980 Podolsky et al. 1978

von kleist et al." 1,974

Ishisi, 1979

Other antigens of potential interest in the study of colorectal carcinomas include substances of ill-defined nature associated with colorectal cancer cells mainly detected by monoclonal antibodies. The techniques involved in the generation of monoclonal antibodies nowadays almost have reached the standard routine level. As a result many reports have been published concerning monoclonal antibodies derived from immunization of mice with colonic carcinoma cell 1 ines, freshly prepared colonic carcinoma cell suspensions or prem purations of colonic cancer cells membranes, some of which are claimed to detect colorectal carcinoma-specific antigens. The main problem with monoclonal antibodies, howewer, lies in the often cumbersome characterization of their target-antigens by various biochemical procedures and the exploration of the distribution of these target-antigens by immunocy tochemical methods on cell ines and tissue sections of various sources (Thompson et al " 1983).

The fate of the 1116 NS19-9 monoclonal antibody deEined, gastrointestinal cancer associated antigen (GICA) nicely iliustrates the pertinence of extensive biochemical and immunocytochemical characterization, before a monoclonal antibody can be hailed as detecting a tumour-specific antigen. Originally the target antigen was claimed to be of on cofetal and glycolipid (monosialoganglioside) nature (Magnani et a 1., 1981) and reported to be restricted to carcers of the colon, stomach and pancreas (Koprowsi et a 1., 1979; Chang et a 1., 1981; Koprowski et al., 1981). Subsequently by immunopecoxidase studies its presence was detected in various normal adult glandular tissues as well as carcinomas of other tham gastrointestinal tract origin (Atkinson et al., 1982). Part of this work has been done by our group and will be discussed in Chapter II (Arends et a1., 1983). Recently the glyoolipid nature of GICA has also become contested (Raux et al., 1983; Magnani et a1. 1984). Monoclonal antibodies which have so far been reported in comection with colorectal cancer are compiled in table $I$. together ith their characteristics. From this table it can 


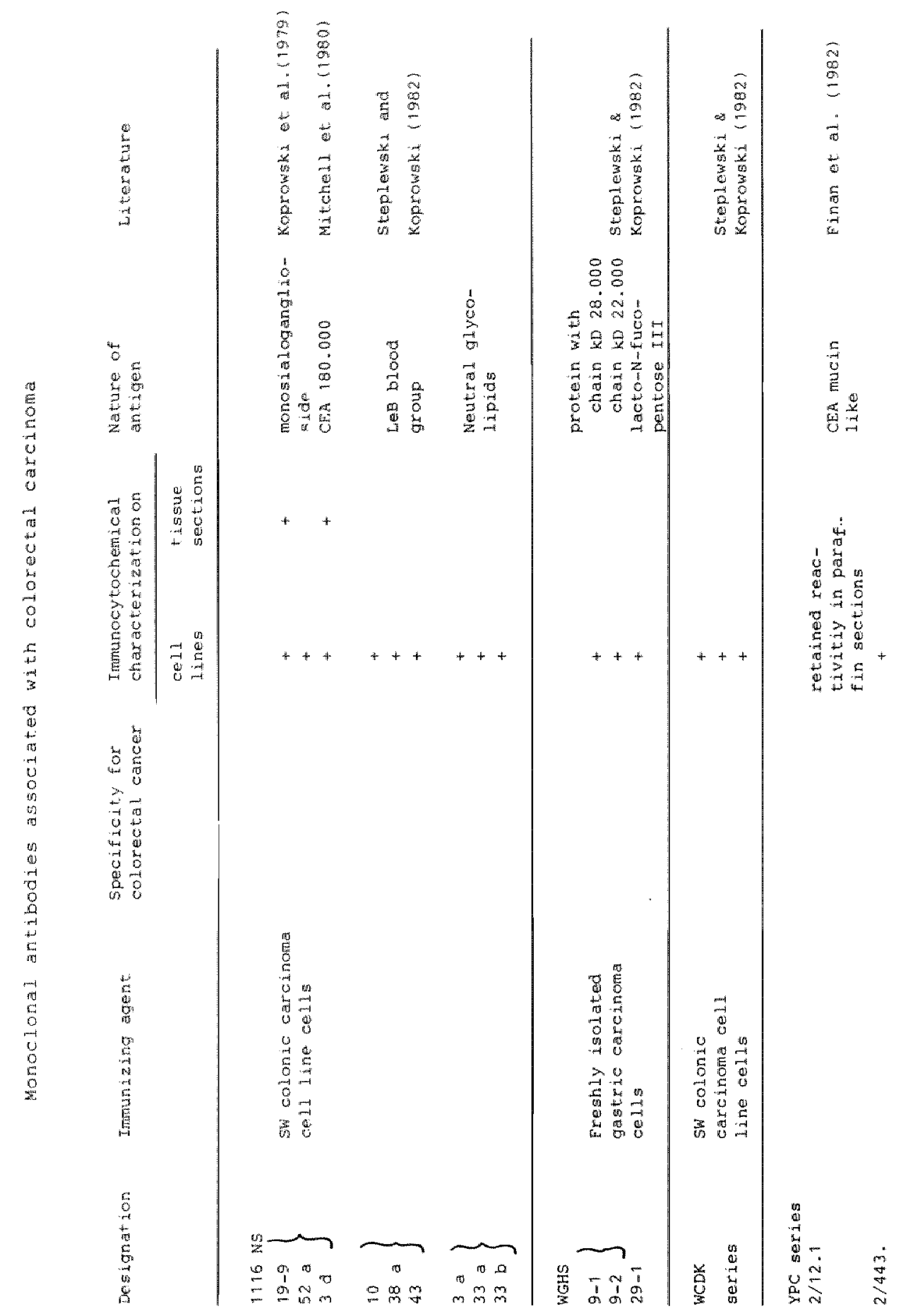




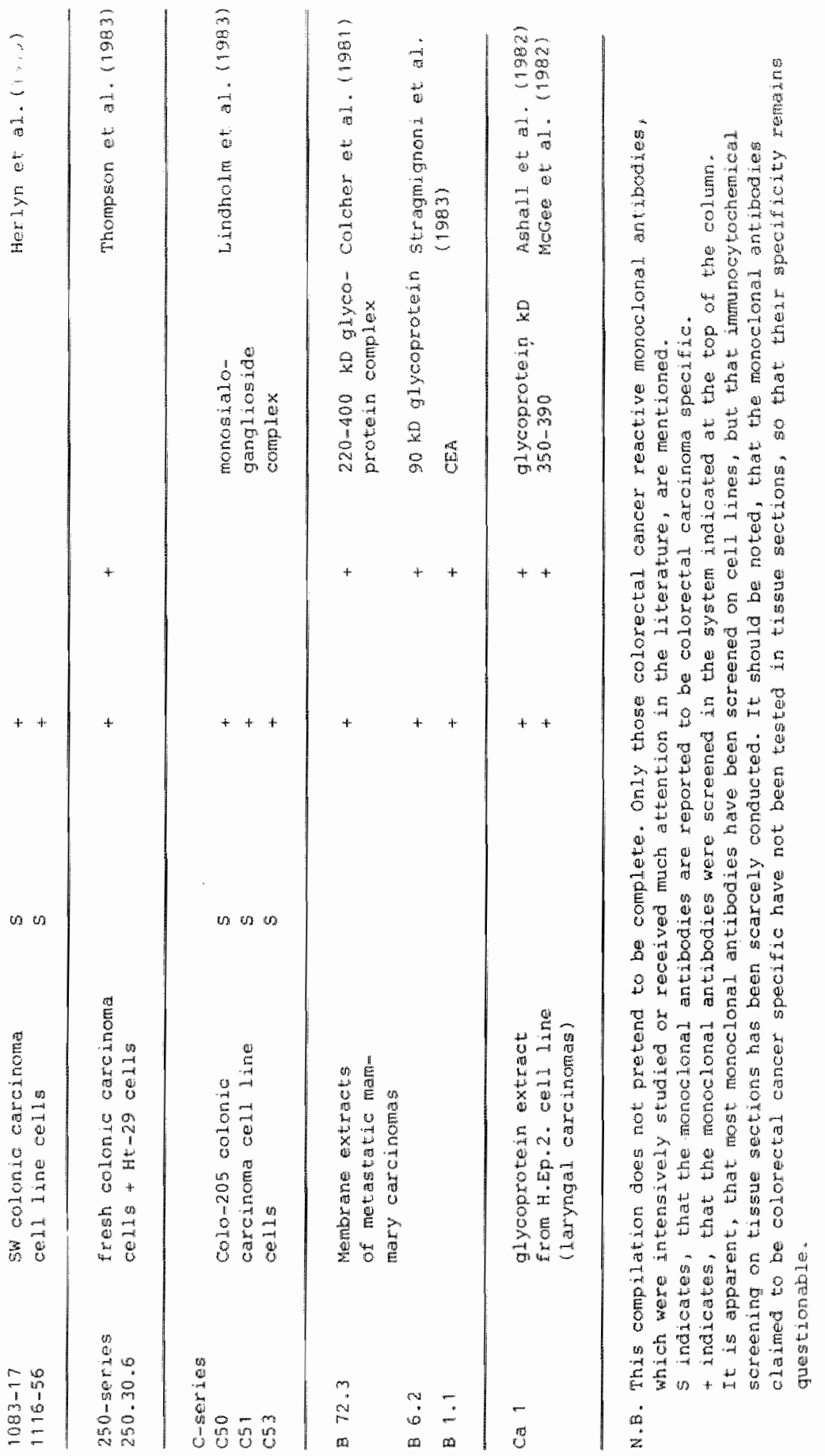


be concluded, that Eew monoclonal antibodies have been studied rigorously enough to substantiate the claim of colorectal cancer specificity.

1.5.2. Tissue-antigens

Tissue antigens may be divided into antigens on cell constituents and on cell products.

a. Cell constituents

Cytoplasic antigens. The existence of intermediate fllament proteins has been identified in alcohol fixed tissue of normal colonic mucosa and colorectal carcinomas (Altmanisberger et a1., 1982). Electron microscopic studies have revealed a gradual disorganization of the three-dimensional network of intermediate tiaments loosely surrounding the nucleus and inserting into lateral desmosomes in colondic tumours of increasing anaplasia (Brown et al., 1983). Since cytoskeletal. antigens seem to be retained even in poorly differentiated carcinomas, their immunocytochemical demonstration may be of great value to type highly anaplastic tumours, which on morphological grounds may be difficult to classify (Altmannsberger et al. 1982).

Membrane antigens. Alterations in composition of membrane antigens, mainly of glycoprotein nature in colorectal adenocarcinomas as compared to normal colonic mucosa have been studjed in respect of various antigens with different techniques. Blood group antigens of the $A$, $B$, system have been detected in about half of rectosigmoid carcinomas by means of red cell adherence tests (Denk et al. "1974; Corper and Haeslex, 1978 ; Abdelfattah-Gad and Denk, 1980) and a Iso with monoclonal antibodies direct against $A$ and $B$ antigens (umpublished observations, Arends et al., 1984). These antigens do not seem to occur in normal adult colonic mucosa, but can be observed in fetal large bowel mucosa (Szulman, 1964).

Also colorectal cancer reactive monoclonal antibodies detecting sugar sequences present on glycolipids of the Lewis bliood group system have been described (Hounsell and Feizi., 1982; Magnani et al., 1982). Blood group antigens predominantly appear to show a patchy expression pattern in colorectal meoplasms (cooper et al. 1980).

The same mode of expression has been reported for HLA-DR antigans, which are detectable by means of monoclonal antibodies on cell lines of colonic cancer (Pollack et al." 1981; Maclean et a 1., 1982) and on about half of the colorectal adenocarcinomas in spite of their absence in normal epithelium (Daar et a1., 1982, Daar and Fabre, 1983). HLA$A B C$ antigens seem to be expressed in normal as well as neoplastic mucosa (Daar and Fabre. 1983).

Lectin affinity studies have been employed to explore the composition of glycoproteins on membranes and in the cytoplasm of colorectal cancer cells and the alteration of these antigens in relation to normal mucosa (Kim et al., 


\section{4; Boland et a 1* 1982; Paulie et al., 1983).}

The epithelial membrane antigen (EMA), which is detected by an antiserum raised against human milk fat membrane globules, has been reported to occur in colotectal (cancer) tissue (Heyderman et 1 . 1979; sloane and ormerod, 1981). Also monocional antibodies generated against human milk fat membranes, like HMFG (TaYlom-Papadimitriou et 1 . 1981) and mam 3 (Hilkens et al "1982) stain colotectal mucosa and colonic neoplasms in a variable staining patern.

\section{b. Cell products}

Normal crypt lining colonic epithelium mainly consists of columar or absorptive cells and mucin producing goblet cells. In the base and deep regions of the crypts some enteroendocrine cells are present. In the nomal situation Paneth cells are not seen, but these can occur in inflamatory and neoplastic conditions.

Goblet cell antigens. Many studies have been devoted to gastrointestinal mucins (for review see filipe et al. " 1979\%. According to conventional histochemical staining techniques colonic mucus appears to be a mixture of neutral. sialo-, and sulphomucins produced by the goblet cells of the epithelium. In nomal colonic mucosa sulphomucins prevail over sid lonucins, whereas neutral mucins are present in only moderate amounts. The composition of goblet cell mucins shows a regional variation over the various segments of the colorectum as well as alterations in relation with the position of the mucin producing cells along the crypt (Greco et al., 1967; Filipe, 1979). Colorectal adenocarcinomas generally demonstrate a predominance of sialomucins over sulphomucins (Filipe et al., 1979; Montero and segura, 1980) and the same situation is observed in mucosa adjacent to these carcinomas, the so-called transitional mucosa (Filipe and Branfoot, 1974; Dawson and Filipe, 1976). Therefore a shift from predominance of sulphomucin production to increased sialomucin secretion in normal colonic mucosa has been taken to indicate a premalignant transformation, a notion which has become contested by the observation that the same changes of mucus prodwction occur adjacent to other types of neoplasia and inflammatory conditions (Isacson and Attwood, 1979; Franzin et a ., 1983).

severa 1 conventional and monoclonal antibodies appear to detect epitopes on mucin substances, which are often poorly biochemically characterized. Some conventional antibodies of this nature are listed below.

Conventional antibodies detecting mucosubstances

designation

Mucus-associated

gastrointestinal antigen abbreviation

M 3
Literature

Bara et al.,1977,$1980 a, b$ 
Integtinall mucosa specific IMG glycoprotein

Goblet cell antigen

Colonit Mucoprotein antigen

Colon-specific-antigen-p CSA-p

"Another oncofetal antigen" -
Kawasaki et al.. 1972,1974

Rapp et a 1.1979

CMA

Gold and Milier, 1974, Gold, 1981

Pant et a1., 1978; Shochat, et al., 1981

Ma et a1., 1980

Columnar cell antigens. Secretory component (SC), a glycoprotein with a molecular weight of $60-70 \mathrm{kD}$ has a carrier transport function in the epithelial translocation of dimeric IgA (Tourville et a l, 1969; O'Daly et a . "1971; Brandtzaeg, 1974; Brown et al., 1976) and has been reported to occur in many epithelia involved in the so-called local secretory immune system (Tourville et al., 1969; Harris and South, 1981). In the large intestine $\mathrm{SC}$ is synthesized by the columar cell population (0.Daly et al., 1971) and as such can be regarded as a differentiation antigen of this type of epithelium. Several reports have been published concerning its immunocytochemical expression in relation to the stage (Rognum et al.r 1980; 1982) and histological grade (Poger et al., 1976; Weisz-Carrington et al., 1976; Green et a1.. 1977; Rognum et a1., 1980, 1982; Isaacson, 1982) of collorectal carcinomas, which will be discussed in greater detail in chapter $v$ of this study.

Enteroendocrine cell antigens. Neuroendocrine cells producing various peptide hormones have been described in the mucosa of the colon and especially the anorectum (Fenger and Lyon, 1982). Carcinoids ( $i . e$. tumours of pure neuroendocrine cell composition) of hindgut origin often react with argyrophilic stains (Hosoda et al., 1975; Taxy et. al., 1980; Fenger and Lyon, 1982; ). Argyrophilic cells can also be observed in combined adenomatous and carcinolid tumours (adenocarcinoids) (Bates and Belter, 1967) and in ordinary well-differentiated adenocarcinomas (U1ich et a $1 ., 1983$ ).

Expression of neuron-specific enolase (NSE), an enzyme, which is generally detected by immunocytochemical methods, has been noticed in most, if not all, cells showing neuroendocrine activity (Schmechel et a 1., 1978) and could therefore be of use in the study of carcinomas with such features of the gastrointestinal tract.

The peptide hormones, which have been detected in normal and neoplastic enteroendocrine cells of the rectosigmoid by immunocytochemical means include glucagon, somatostatin, gastrin, motilin, secretin, neurotensin, glicentin, pancreatic polypeptide, enkephalin and $B$-endorphin (Alumets 
et a 1., 1980; Ulich et a 1. "1983; E10cca et al. 1980* 0 "Brian et a1., 1982; Yang et a1. 1983; Alumets et al. 1981).

Paneth cell antigens. Lysozyme, an enzyme capable of lysis of bacterial cell walls (Chipman and Sharon. I969: Hill and Porter, 1974) is a product of Paneth cells (Ghoos and Vantrappen, 1971; Peeters and Vantrappen, 1975; ; K100kars and Reitama, 1975). In normal colonic mucosa immunareactivity for lysozyme is absent (Mason and Taylor, 1975; Kittas et a 1." 1982), but immunoreactive cells can be seen in inflamed epitrelium (Watson and Roy, 1960) and mucosa adjacent to carcinomas (Symonds, 1974). In general the enzyme is not expressed in colorectal carcinomas with exception of metaplastic Paneth cells which may occur in these tumours (Holmes, 1965; Gibbs, 1967), but the colloid variety demonstrates strong cytoplasmic immunoreactivity for lysozyme, often in combination with neuroendocrine features (Arends and Bosman, 1983).

1.6. Antigen-specificity in colorectal carcinomas

In the previous paragraph we have described the most relevant antigens in colorectal carcinomas. We will now address the prablem of their specificity more explicitly in view of the fact that the identification of an antigen occurring exclusively on colorectal (tumour) cells and not on other meoplastic or normal adult tissues would be of tremendous help for the characterization and classification of colorectal. carcinomas as well as the demonstration of metastatic lesions as of colorectal origin (vide 1.2, sub a).

Antigen-specificity may be related to the unique expression of an antigen in a special type of tumour or to its exclusive occurrence in normal tissues of a given histological type and in their derivative neoplasms.

As indicated in 1.5.1. monoclonal antibody-defined antigens, originally believed to be colorectal cancer-specific, fail to meet the claim of specificity after more extensive study and other antigens reported to be of such nature have not yet been explored rigorously enough to substantiate their hailment as "colorectal-specific". As a result at this moment no tumour-specific antigens have been conciusively established in colorectal carcinomas.

Likewise, tissue-antigens specific for colorectal epithelial celis and their derivative tumours as yet have mot been convincingly demonstrated. Cellular constituents, such as intermediate filaments and the majority of membrane glycoproteins also accur in other histological tissue types and the same situation applies to cellular products such as mucins, SC, peptide hormones and lysozyme.

Therefore, attempts to type colorectal carcinomas and to identify metastatic lesions as of colorectal origin are Erustrated by the lack of specificity of the available antigens and as yet remain unsatisfactory. 
However, despite the apparent lack of specificity of the antigens studied in connection with colorectal carcinomas deternination of thesr expression may still be of use to classify colorectal tumours according to their parental. cell type, differemtiation or stage o maturation.

\subsection{Phenotyple heterogeneity of antigen expression}

The recognition that tumours are nat uniform entities consisting of cells with similar properties, but are highly heterogeneous and contain multiple subpopulations of cells with different properties, is steadily increasing (see for excllent reviews Eidlex and Haxt, 1982; Paste, 1982; Woadrufe, 1983). First of all, neoplasms contain normal cells (inflamatory cells, blood vessels), transformed cells, cells conceivably having taken some but not all necessary stops in the development towards malignancy (initiated cells) and possibly also hybrid cells (created by fusion of two cells of the same or different categories). Furthermore, some neoplastic celis are so-called clonogenic cells, which are responsible for infiltrative growth and metastasis of neoplasms.

obuiously, these clomogenic cells are the main targets of research concerning the biological behaviour and manipulation of neoplastic growth and these cells hawe also been shown to be heterogeneous in respect of their DNA content (Peterson et a 1., 1978; Vindelov et a.., 1980), growth rate (Butel et al., 1977) antigenic composition (Prehn, 1970; Rutzky and Siciliano, 1982 ) metastatic potential (Brattain et a 1., 1980; Spremulli et a1., 1983) and response to cytotoxic drugs (Barfanco et a 1., 1973).

The implications of the phenomenon of phenotypic heterogeneity of antigen expression in respect of the potential clinjcopathological value of determination of antigenic display, as outlined in 1.2 . a and $b$, are apparent.

Heterogeneity of antigen expression may limit the potential value of determination of antigenic composition in regard of the characterization and classification of primary tumours and metastases of unknown origin (vide 1.2. sub a). The typing of primary tumours may become impossible, when an area of a given tumour is studied, which happens to be devoid of the antigen umder investigation. An even more important problem, however, may arise in the typing of metastatic tumours. Since experimental data indicate, that tumours consist of subclones of tumout cells with a widely differing metastatic potential, it is conceivable, that as a result of clonal selection during the evolution of metastases the antigenic composition of neoplastic cells in metastatic tumours may be more restrictad than in the parental tumours (Fidler, 1978). The existence of such a phenomenon would clearly thwart the identification of metastatic lesions according to their antigenic display and aso would gravely interfere with immunotargeting procedures, which especially. 
when applied with therapeutic options, are meant to reach as many tumour cells as possible.

phenotypic heterogeneity of antigen expression in tumours in addition may form an important obstacle in procedures a ined at the assessment of the grade of malignancy (vide 1.2 . sub b). These procedures generally rely on the stablishment of a correlation between antigen expression and other clinicopathological variables of known prognostic significance. Many of these variables demonstrate heterogeneity per se, as e.g. histological grade (Qualheim and Gall, 1953), which in addition to stage of tumour extension, is known to be an important prognostic index in colorectal tumours. In the simple over-all classification of antigen expression into categories of "positive", "focally positive" or "negative" and histological grade into well-" moderately- and poorly differentiated, which for practical purposes are commonly performed, the intercellular heterogeneity of both parameters is not taken into account. Thus correlations which might exist between these parameters at the individual cell. level might be obscured. Also, apart from these practical considerations, by the virtue of simple immunocytochemical demonstration the significance of an antigen heterogeneously expressed in one or more subciones of a neoplasm may be impossible to assess in terms of the biological behaviour of: the tumour as a whole.

In view of this situation it may not be surprising that the expression of blood group antigens of the $A, B$, $H$ type and antigens of the HLA systems, which often show a focal expression pattern do not appear to be related with the histological grade of colorectal carcinoma (Abdelfattah-Gad and Denk, 1980). Also the prognostic signiticance of mucus production by colorectal carcinomas remains controversial (Trimpi and Bacon, 1951; wolman et al. 1957; Symonds and Vickery, 1976; Pihl et a 1., 1980), probably due to improper delineation of the type and the extent of mucin expression by these tumours.

Since several reports indicate a correlation between the expression of $\mathrm{sC}$ and histological grade Poger et al." 1976; Weisz-Carrington et al., 1976; Green et al. " 1.977; Rognum et al., 1980, 1982; Isacson, 1982) as well as stage (Rognum et a 1., 1980, 1982) of colorectal carcinomas, this antigen so far appears to be one of the fiew with a potential prognostic value.

\subsection{Design of the study}

From the outline given in the previous paragraphs based on a review of the literature it may be apparent that the demonstration of tumour-amtigen expression may have its potential value in regard of the characterization and slassification of primary tumours and metastases as well as the assessment of the grade of malignancy but at the same time is subject to Iimitations posed by the problems of antigen- 
The present study addresses these topics of apparent relevance to the study of tissue antigen expression in connection with colorectal carcinomas.

Chapter II deals ith the problem of antigen-specificity in respect of the monoclonal antibody 1116 NS $19-9$ defined monosialoganglioside or gastrointestinal cancer associated antigen (GICA), because of its original hailment as an oncofetal, non CEA related antigen occurring on some gastrointestinal cancers, but not on normal adult tissues. In chapters III, IV and $V$ the potential values in respect of prognosis are evaluated in regard of GICA and $S C$.

The toplc of heterogeneity of antigen expression is addressed in Chapter VI in connection with the extent of phemotypic heterogeneity of antigen expression in primary colorectal tumours and possible differences in antigen profile between primary tumours and their regional lymphnode as well as hematogenous metastases. At the same time the interference of antigen heterogeneity in primary and metastatic tumours ith the efficacy of immunotargeting procedures has been considered.

Chapter VII, the epilogue, summarizes the results of the study and evaluates the present 1 imitations and future perspectives of tissue detection of tumour-antigens in colorectal cancer in the context of the data obtained. 
Abdelfattah-Gad, M. Denk, H. Eplthellal blood group antigens in human carcinomas of the distal colon: further studies on their pathologlc significance. JNCI; 64 : 1025-1028, 1980

Accolla, R.S., Carrel, S. Mach, J.P. Monoclonal antibodtes speciflc for carcinoembryonic antigen and procedure by two hybrid cells lines. Proc.Natl. Acad.Sci.; 77: 653-566, 1980

Ahnen, D.J., Nakane, P.K., Brown, W.R. Ultrastructural localization of carcinoembryonic antigen in normal intestine and colon cancer. Cancer; $49: 2077-2090,1982$

Altmannsberger, M., Weber, K., Hölscher, A., Schauer, A., Osborn, M. Antibodies to intermediate filiaments as diagnostic tools, Lab. Invest." $46: 520-526,1982$

Alumets, J., Falkmer, S., Hakanson, R., Ljungberg, 0., Martensson, M., Sunder, F." Tibblin, S. Immunohistochemical evidence of peptide hormones in endocrine tumours of the rectum. Cancer; $48: 2409-2415,1981$

Alumets, J., Falkmer, S. . Grimelius, L., Hakanson, R., Lijungberg, 0., Sunder, F., willander, E. Immunocytochemical demonstration of enkephalin and $B-E n d o r p h i n$ in endocrine tumours of the rectum. Acta Pathol. Microbiol. Scand. (A); 88: 103-109, 1980

Arends, J.W., VerstlJnen, C., Bosman, F.T., Hilgers, J., Steplewski, Z. The distribution of 1116 MS $19-9$ monocional antibody defined monosialoganglioside in normal and cancerous human tissues. Hybridoma; 2: 81-91, 1983

Arends, J.W. and Bosman, F.T. Signet-ring cell carcinoma of rectum. Histopathology: $7: 135-136,1983$

Astha11, F., Bramell, M.E., Harris, H. A new marker for human cancer cel1s. 1. The Ca antigen and the Ca anthody. The Lancet; 3 July: 1-6, 1982

Asha11, F*, Brambe11, M.E. Harris, H. A new marker for hum cancer cells. 2. Immunohistochenical detection of the Ca antigen in human tissues with the Cat antibody. The Lancet; 7-10, July 1982

Atkinson, B.F., Ernst, C.S., Herlyn, M., Steplewskl, $z .$, Sears, H., Koprowsi, H. Gastrolntestinal cancer-associated antigen in immunoperoxidase assay. Cancer Res.; $42: 4820-4823,1982$

Avrameas, S. Coupling of enzymes to proteins with glutaraldehyde. Use of conjugates for the detection of antigen and antibodies. Irmunochemistry; 6: $48-52,1967$ 


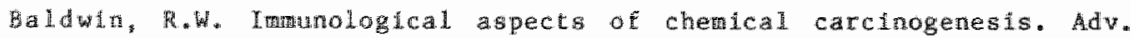
Cancer Res.; 18: 1-75, 1973

bara, \# Burtin, P. Mcus-associated gastrolntestinal antigens in trangitional meosa adjacent to hum coloric adenocarcinomas: their fetal-type association. Eur. J. Cancer: 16: 1303-1310, 1980a

Bara, $J_{*}$, Lotolllier, $F_{*}$, Burtia, $P$. Antigeng of gastric and intestinal Tucous celle in human colonic tumours. Br. J. Cancer; 41: 209-221, 1980b

tara, J., Malarewicz, A. "Loidilier, F., Burein, P. Antigens comon to humaru ovarlan wucinous cyst thid and gastric mucosa. Br. J. Cancer" 36 : 49,1977

Barranco, S.C., Drewinko, B., Humphrey, H.M. Differential response by human melanotia cello to $1, y-(b 1 s)-(2-c h l o r$ thethyl $)-1$ nitrosourea and bleonycin. Mutat. Res.; 19:277-280, 1973

Bater, H.R., Belter, L.F. Composite carcinold tumour (argenthaflnomadenocarcinomay of the colon: report of two cases. Dis. Col. Rect.; $10: 467-470,1967$

Belpome, D., Mathe, G., Davies, A.J.S. Clintcal signiflcance and prognostic value of the $T-B$ immological classification of human primary acute lymphold leukaemias. lancet; 1: $555-558$, 1977

Berche, C., Mach, J.P., Lumbroso, J.D., Lamglais, C., Aubry, L., Buchegger, P., Parmentler, C., Tublana, M. Tomoscintigraply for detecting gastrointestinal and medullary thyroid cancers: first clincal results using radlolabeled monoclonal antibodies agalnst carclnoembryom nic antigen. Br.Med.J.; 285: 1447-1451, 1982

Boland, C.R., Montgomery, C.K., KH, Y.S. Alterations in human colonic muctn occurling with cellular differentiation and malignant transfor mation. Proc. Nat1. Acad. Sc1.; 79: 2051-2055, 1982

Bosman, F.T. Some recent developments in immocytochemistry. Histocherth. J.; 15: 189-200, 1983

Brandtzaeg, P. Mucasal and glandular distribution of inmunoglobulin componenes: Differential localization of free and bound SC in secretory epithellat cellow. J. Innunot.; 112: 1553-1559, 1974

Drattain, M.O., Strobel-Stevens, J., Fine, D. Webb, M. , Sarrif, A.M. Fatablisherent of mouse colonic-carcinoma cell Hnes uth different metastatic properties. Cancer. Res.; 40:2142-2146, 1980

Brouet, J.Cm, Seligman, M. The inmological classflication of acute 1 ymphoblasife leukenias. Cancer; $42: 817-827,1978$

Brown, D.T., Anderton, B.H., Wylle, C.C. The arganization of intermediate filanents in nomal human colonic epithelium and colondc careinoma cells. Tut. J. Cancer; $32: 163-169,1983$ 
Brown, W.R., Isobe, Y., Nakane, P.K. Studies on localization of Iminoglobulins across intestinal epthelium II. Inmunoelectron microsicopic localization of famunoglobulins secretory component in human intestinal mucosa. Gastroenterology; 71: $985-995,1976$

Buchegger, E., Phan, M., Rivier, D., Carrel, S., Accolla, R. S., Mach, J.P. Monoclonal antibodies agalnst carcinoembryonic antigen (CEA) used in a solid-phase enzyme immunoassay. First clinical results. J. Inmunol. Meth.; $49: 129-139,1982$

Buckley, C.H., Fox, H. An immonolistochemical study of the significance of HCG secretion by large bowel adenocarcinomasta. I. Clin. Pachol.; 32 : $368-372,1979$

Burtin, P., Chawanel, G., Hirsch-Marie, H. Characterization of a second normal antigen that crossmreacts with CEA. I. Tumunol.; $111: 1926-1928$, 1973

Butel, J.S., Dudley, J.P. Medina, D. Comparison of the growth propertics In vitro and transplantability of continuous mouse mamary tunour cell lines and clonal derivatives. Cancer Res.; 37: 1892-1900, 1977

Chang, T.H., Steplewskl, Z., Sears, H.F., Korprowskl, H. Detection of monoclonal antibody-defined colorectal carcinona antigen by solid-phase binding inhibition radioimmunassay. Hybridoma; $1: 37-47,1981$

Chipman, D.M., Sharon, N. Mechanism of lysozyme action. Sclence; 165 : 454,1969

Chiu, J.F., Puno, D., Gootnick, D. Antigenic changes in nuclear chromain in 1,2-dimethylhydrazine-induced colon carcinogenests. Cancer; 45 : $1193-1198,1980$

Ghoos, Y., Vamtrappen, G.R. The cytochemical locallization of lysozyme in Paneth ce11 granules. Histochem. J.; 3: 175-178, 1971

Colcher, D., Hand, P., Nuti, M., Schlom, J. A spectrum of monoclonal. antibodies reactive with humar mammary tumour cells. Proc. Nat. Acad. Sci.; $78: 3199-3203,1981$

Coons, A.H., Creech, H.J., Jones, R.N. Inmunologicall properties of an antibody contalning a fluorescent group. proc.Soc.exp. Blol.; 47 : $200-0202,1941$

Cooper, G.M., Okenquist, S., Silverman, L. Transforming activity of DNA of chemically transformed and normal cel1s. Nature; 28:4:418-421, 1980

Cooper, H.S., Cox, J., Patchefsky, A.S. Immunohistologlc study of blood group substances in polyps of the distal colon. Am. J. Clin. pathol.; 73: $345-350,1980$

Cooper, H.S., Haesler, W.E. Jr. Blood group substances as thuour antigens in the distal collon. Am. J. Clin. Pathol.; 69: 5944-598, 1978 
Culling, C.I.A., Reld, P.E., Durn, W.L. A new histochemlcal method for whe thentiflcation and visualization of both side chan acylated and non-acylated walc acids. J. Histochemistry and Cytochemistry; 24 : $1225-1230,1976$

Curram, R.C., Gregary, J. Effects of flxation and processing on 1mmunohistocehnical demonstration of Immunoglobulin in paraffin ections of tonstil and bone marrow. J. C1in.Pathol.; 33: 1047-1057, 1980

Daar, A.S., Fuggle, S.V., Thing, A., Fabre, J.H. Anomalous expression of HLA DR antigens on human colorectal cancer cells. J. Imunology; 129: $447-4.49,1982$

Daar, A.S. Fabre, J.W. The membrane antigens of human colorectal cancer cells: Demonstration with momoclonal antibodies of heterogenelty within and between tumours and of anomalous expression of HLA-DR. Eur. J. Cancer Clin. Oncol.; 19:209-220, 1983

Dalla-Favera, R., Bregnl, M., Erikson, J., Gallo, R.C., Croce, C.M. Human c-myc onc gene is located on the region of chromosome 8 that is cranslocated in Burkit lyaphoma cells. Proc. Nat1.Acad.sci.; $79: 7824-7827,1.982$

Dawson, P.A., Filipe, M.I. An ultrastructural and histochemical study of the mucous membrane adjacent to and remote from carcinoma of the colon. cancer; $37: 2388-2398,1976$

Dekletn, A., Geurts van Kessel, A., Grosveld, G, et al. A cellular oncogene is translocated to the Philadelphia chromosome in chronic myelocytic leukaemia. Nature; 300: 765-767, 1982

Delell1s, R.A., Sternberger, L.A., Mann, R.B., Banks, P., Nakane, P.K. Immunoperokidase technics in diagnastic pachology. Am.J.CIn.Pathol.; $71: 483-488,1979$

Denk, H., Tappefner, G., Davidovits, A. et al. Carcinoembryonic antigen and blood group substances in carcinomas of the stomach and colon. $J$. Natl. Can. Inst.; 53: $933-941,1974$

Diamond, B.A., Yelton, D.E., Scharff, M.D. Monoclonal antibodies. A new technology for producing serologic reagents. N. Engl.J. Med.; $304:$ $1344-1349,1981$

Duhl, D.M., Banjar, Z., Brtggs, R.C., Page, D.L., Hnilica, L.S. Tumor-assoctated chromatio antigens of human colon adenocarcinoma cell Lineg HT-29 and Lowo. Cancer Res.; 42: 594-600, 1982

Dulbecco, R., Unger, M., Bologna, M., Battifora, H., Syka, P., Okada, S. cross reactivity between thy-l and a component of intermediate filaments demonstrated using a monoclonal antibody. Nature; 292: 772-774, 1981

Ehrlich, P. Collected studes tn Immulty. John wiley and Sons, New York, pp. $441-442,1906$ 
Falint, B., Taylor, C.R. New developments in immoperoxidase techniques and their application. Arch.Pathol.Lab.Med.:107: 105-117, 1983

Fenger, $C .$, Lyon, H. Endocrine celis and melanin-contalning cells in the anal canal epithelium. Histochem. J.; 14:631-639, 1982

Fidler, I.J. Tumour hetarogeneity and the biology of cancer invasion and metastasis. Cancer Res.; $38: 2651-2660,1978$

Fidier, I.J., Hart, I.R. The development of blological diversity and metastatic potential in malignant neoplasms. Oncodev.Biol. Med.; 4 : $161-176,1982$

Filipe, M.I. Mucins in the human gastrointestinal eplithelium: a review. Invest. Cell. Pathol.; 2: 195-216, 1979

Filipe, M.I., Branfoot, A.C. Abnormal patterns of mucus sectetion in apparenty normal mucosa of large intestine with carcinoma. Cancer; 34 : $282-290,1974$

Finan, P.J., Grant, R.M., Mattos de, C., Takej, F., Berry, P.J., Lennox, E.S., Bleehen, N.M. Irmunohistochemical techniques in the early screening of monoclonal antibodies to human colonic eptehelium. $\mathrm{Br}$. J. Cancer; $46: 917,1982$

Fiocca, R., Capella, C., Buffa, R. "Fontana, R., Solcla, E., Hage, E., Chance, R.E., Mody, A.J. Glucagon-, glicentin-, and pancreatic polypeptidelike immunoreactivities in rectal carcinoids and related colorectal cells. Am. J. Pathol.; 100: 81-92, 1980

Foley, E.J. Antigen properties of methylcholanthrene-induced tumors in mice of strain of origin. Cancer Res; $13: 835,1953$

Franzin, G., Grigloni, W.F., Dina, R., Scarpa, A., Zamboni, G. Mucin secretion and morphological changes of the mucosia in non-neoplastic diseases of the colon. Histopathology; 7: 707-718, 1983

Fuks, A., Banjo, C., Shuster, J., Freedman, s.a., Gold, P. Carcinoembryonic antigen (CEA): molecular blology and cilnical significance. Biochem. Biophys.Acta; 417; 123-152, 1974

Gabryelak, T., Pumo, D.E., Chit, J.E. Changes in tumor-specific nuclear antigen actulty in carcinogen-treated colon by tumor promotor and carcinogen inhibitors. Cancer Res.;4: $3392-3394,1981$

Gallyas, $F_{*}$, Coxcs, $T$, Merckenthaler, $T$. High grade intensification of the end product of the diaminobenzidine reaction for peroxidase histochemistry. J. Histochem. Cytochem,; 30: 183-184, 1982

Gallan1, S., Ming Chu T., Nussbaum, A., Ostrander, A., Christofi, N. Human choriontc gonadotrophins (hCG) dn non-trophoblastic neoplasms. Cancer; $38: 1684-1686,1976$

Gibbs, N.M. Incidence and significance of argentaffin and Paneth cells 
in wothe twar of the large intestine. J. Clin. Path.; 20: 826-831, 1967

Gold, P., Freenan, S.O. Demonstration of tumor-specific antigens in humari colonic carcinoma by dnunological tolerance and absorpton techntques. J. Exp.Hed, 121:439-462, 1965

Gold, $P .$, Freman, 5.0. specific carcinoembryonic antigens of the fuman digestive sygten. J. Exp.Med.; $122: 467-481,1965$

Gold, D.V. Immunoperoxidase localization of colonic mucoprotein antigen in neopllastle tigeves. Cancer Res.; $41: 767-772,1981$

Gold, D.V., M11.er, F. Characterization of human colonic mucoproteln antigen. Imrunohlstochemistry; 11: $369-375,1974$

Cold, E.R. Balding, $p$, Receptor-speciflc proteins. Excerpta Medica, Amsterdam, 1975

Golderberg, D.M., Shockey, R.M., Primus, F.J. Carcinoembryonic antigen in higtopathology: Lmmoperoxidase stalning of conventional tissue sections. J. Nat1. Cancer Inst; ; $57: 11-22$ * 1975

Goldenberg, D.H. KH, E.E., Deland, F.H., Bennett, S., Primus, E.J. Radiolmunodetection of cancer with radioactive antibodies to carcinoembryonic antigen. Cancer Res.; $40: 2984-2992,1980$

Goldenberg, D.M., Neville, A.M., Carter, A.C., Go. V.L.H., Holyoke, E.D., Isselbacher, K.J., Schien, P.S., Schwarts, M. CEA (carcinoembryonic Antigen): its role as a marker in the management of cancer. J. Cancer Res.cilin.Oncol.; 101: 239-242, 1981a

Goldenberg, D.M., Gaffar, S.A., Bennett, S.J., Beach, J.L. Experimental radiolnmunotherapy of a xenografted human colonic tumor (GW 39) producting carcinoembryonic antigen. Cancer Research; $41: 4354-4360$, $198 \mathrm{~B}$

Gray, B.N., Walker, C., Barnard, R., Bennett, R.C. Tenessee antigen: the predictive value of preoperative and postoperative assays in large-bowel cancer. Dis, Colon Rectum; 25: 539-541, 1982a

Gray, B.N., Halker, C., Barnard, R., Bennett, R.C. Tennessee antigen: 1ts value in the montortng of patients with colorectal cancer. Dis. Colon kectum; 25: $542-544,1982 \mathrm{~b}$

Greaves, M. . Analysis of the clinical and biological signiflcance of lymphold phenotypes in acute leukenta. Cancer Res.; 41: 4752, 1981

Greco, V., Larro, G., Fabrinl, A., Torsoli, A. Histochemistry of the colonfo eplthellal muetns in mormal subjects and in patients with ulcerative colitis. A qualitative and histophotometric investigation. Gut; $8: 491-496,1967$

Green, F.H.Y., Whitehead, S., Fox, H. Abnormalities of the local immune 
system in intestinal neoplasia: a morphological study 1 . Path * 122 : $55-61,1977$

Grimelius, L. A silver nitrate stain for alpha -cells in huma pancreatic islets. Acta Societatis Medicortu Uppsalensis; $73: 243,1968$

Harris, J.P., South, M.A. Secretory component, a glandular ephthellal cel1. warker. An. J. Pathol.; 105: 47-53, 1981

Heald, J., Buckley, C.H., Fox, H. An immunohistochemiccal study of distribution of carcinoembryonic antigen ln epithelial tumors of the ovary. J. Clin.Pathol.; 32 : 918-926, 1979

Hedin, A., Wahren, B., Hammarstrom, * Tumor localization of CEA-containing human tumors in nude mice by means of monoclonal antimeEA antibodies. Int.J.Cancer; $30: 547-552,1982$

Herlyn, M., Steplewski, Z., Herlyn, D., Koprowski, H. Colorectid carcinoma-specific antigen: Detection by means or monoclonal antbodies. Proc. Natl. Acad. Sc1.; 76: 1438-1442, 1979

Heyderman, E., Steele, K., Ormerod, M.G. A new antigen on the epithellal membrane : its immonoperoxidase localization fa normal and neoplastic tissue. J. Clin. Pathol.; 32: 35-39, 1979

Mill, I.R., Porter, P. Studies of bactericidal activity to Escherichia coli of porcine serum and colostral immunoglobulins and the role of ly sozyme with secretory IgA. Inmunology; 26: 1230-1250, 1974

Hill, T.A., McDowell, E.M., Trump, B.F. Locallzation of carcinoembryontc antigen (CEA) in nomal, premalignant and malignant lung rissue. In: Carcinoembryantc Proteins. vol. II. (Ed. E.G. Lehmann) Blomedical Press, Elsevier North-tolland, 1979

Hilkens, J., Buys, F., Hilgers, J., Hageman, Ph., Sonneberg, A., Koldowski, U., Karanda, K. . v. Hoeven, R.P. Feltkamp, C. and v.d. Rijn, J.M. Monoclonal antibodies against human milkfat globule membranes detecting dfferentiation antigens of the mamary gland. Prot.Biol.Fluids; $29: 813-826,1982$

Holmes, E.J. Neoplastic Paneth cells. Their occurrence in two adenomas and one carcinoma of the colon. Cancer; $18: 1416,1965$

Hosoda, S., Kito, H., Mogak1, M. ,Masumori, S., Ito, S. Is rectal carcinold argyrophilic? D1s. Col. \& Rect." 18: 386-390, 1975

Hounsel1, E.F., Feizi, T. Gastrointestinal mucins. Medtcal Blology: 60: $227-236,1982$

Hutric, E., Laumonier, R., Burtin, P., Won Rlelst, S., Chavonal., G. An optical and ultrastructural study of the localization of carclinoenbryonic antigen (CEA) in normal and cancerous human rectocolonfic mucosa. Lab. Invest.; 34:97-107, 1976 
Imal, K., Fulta, H. , Morlya, Y, Tanda, M., Endo, T., Kawaharada, M*, Dempo, K., Hori, T., Yachi, A. Immunohistological distribution of the antigenetic deterninants recognized by monoclonal anclbodles reacting w th carcinombryonic antigen. Prot. Blol.F1ulds; $31: 805-808,1984$

Isaacson, P., Judd, M.A. Immunohistochemistry of carcinoembryonlc ant lgen in the smal1. Intestine. Cancer; $42: 1554-1559,1978$

Isaacson, P. Immonoperoxidase study of the secretory immunoglobulin system in colonic neoplasta. J. Clin. pathol. $34: 14-25,1982$

Isacbon, P. Atwood, P.R.A. Fallure to demonstrate specificity of the morphologleal and histochemical changes in mucosa adjacent to colonic carcinoma (transtional mucosa). J. Ciln. Pathol.; 32: 214-218, 1979

Ishl1, M. Clintcal usefulness of basic fetoprotein for immuno-diagnosis of human cancer In: Herberman R.B. (Ed.)" Coapendilu of Assays of Imanodlagnosis of human Cancer. Elseviter North-Holland Blomedical Presis, Pp. $45-50,1979$

Jobsis, A.C., De Vries, G.P., Anholt, R.R.H., Sanders, G.T.B., Demonstration of the prostatic origin of metastases. Cancer; 41 : $1788-1793,1978$

Jonda1, M., Wigzell, H., Alut1, F. Human lymphocyte subpopulations: Classiflcation according to surface markers and or functional characteristics. Transplant. Rev.; 16:163-196, 1973

Kawa saki, H., Imasato, K., Nakayama, K., Aklyama, K., Kimoto, E., Takeuchl, M. Immunofluorescent staining of mucosal glycoprotein of human Intestinal mucosa. Acta Histochem. Cytochem.; $5: 26-32,1972$

Kawasak1, H., Kimoto, E. Mucosal glycoproteins in carcinoma cells of the gastrolntest 1 nal tract as detected by immonofuorescence technique. Acta Path. Jap.; $24: 481-494,1974$

Kin, Y.S., Isaacs, R., Perdomo, J.M. Alterations of membrane glycopeptides in human colonic adenociarcinoma. Proc. Nat1. Acad. Sc1.; $71: 4869-4873,1974$

K1ttas, C., Aroni, K., Kotsis, L. "Papadimitriou, C.S. Distribution of 1 ysozyme, a -antichynotrypsin and a -antitrypsin 1 adenocarcinomas of the starach and large intestine. Virchows Arch; 398: 139-147, 1982

Khoo, S.K., Whener, N.L., Lie, J.T., Mackay, I.R. Carcinoembryonicc antigenfic actlvity of tissue extracts. A quantitative study of malignnt and benign neoplasms, clrchotic liver, normal adult and fetal organs. Int.J.Cancer; 11: $681-687,1973$

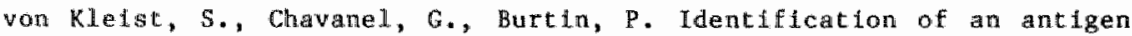
from normal human tissue that crassreact with the carcinoembryonic antigen. Proc.Nat1.Acad.Sci.; 69: 2492-2494, 1972

von Klelst, S., King, M., Burtin, P. Characteristles of a normal tis- 
sular antigen extracted from human colonic turisors. Imunocytochemiscry; 11. $249-253,1974$

Klockars, M., Reitamo, S. Tissue distribution of lysozyme in man. J. Histochem. Cytochem; $23: 932,1975$

Kohler, G., Milstein, C. Continuous culture of fixed cells secreting antibodies of predefined specificity. Nature: $256: 495-497,1975$

Koprowski, H., Herlyn, M., Steplewski, 2., Sears, H. F. Speclflc antigen in serum of patients with colon carcinoma. Sclence; $212: 53-55,1981$

Koprowski, H., Steplewsi, z., Michell, K., Herlyn, M., Herlyn, Di, Fuhrer, colorectal carcinoma antigens detected by hybridoma antibodies. Som. Ce11 Genet.; 5: 957-972, 1979

Kupchik, H.Z., Zurawski, V.R., Hurrel1,J.G.R., Zamcheck, N., Black, P.H. Monoclonal antibodies to carcinoembryonic antigen produced by somatic ce11 fusiom. Gancer Res.; $41: 3306-3310,1981$

Kuroki, M., Koga, Y., Matsuoka, Y. Purification and characterlzation of carcinomembryonic antigens in normal adult feces.

Leathem, A,m Atkins, N. Lectin binding to forralin-fixed parafine sections. J. Clin.Pathol.; 36"7 747-750, 1983

Lindgren, J., Wahlstrom, B. B., Hurme, M., Makela, 0. Immunoperoxidase stalining of carcinoembryonic antigen with monoclonal antibodies in adenocarcinomat of the collon. Histochem.; 74: 223-227, 1982

Lindholm, L., Holmgren, J., Svennerholm, L., Eredman, P., N1lsson, O., Persson, B., Myrvold, H., Lagergard. Monoclonal antibodies against gastrolntestinal tumour-associated antigen 1 solated as monosialogangliosides. Int. Archs. Allergy App1. Lmon.; 71:178-181, 1983

Ma, J., Boer de, W.G.R.M., Ward, H.A., Nalrn, R.C. Another oncofoetal antigen in collonic carcinoma. Br. J. Cancer; 41: 325-328, 1980

Mach, J.P., PusztaszerI, G:. Carcinoembryonic antigen (CEA): demomstration of a partial betkeen CEA and a normal glycoprotein. Imimunocher. ; 9: 1031, 1972

Mach, J.P., Buchegger, F., Fornl, M*, Retachard, J., Berche, C., Lumbroso, J.D. Schreyer, M., Glrardet, G., Accolla, R.S., Carrel, S. Use of radiolabeled monoclonal anti-cEA antibodies for the detection of human carcinomas by external photoscanning and tomoscintigraphy. Immunology today; december: $239-249,1981$

Maclean, G.D., Seehafer, J., Shaw, A.R.E., Kleran, M.W. , Longenecker, B.M. Antigenic heterogenejty of human colorectal cancer cell 11 ines analyzed by a panel of monoclonal antibodies. II. Heterogeneous expression of la-like and HLA-like antigenfc determinants " NCI; 68 : $357-363,1982$ 
Magnara, J.L., Brockhaus, M, Smith, D.F., Ginsburg, V, Blaszczyk, Min Mitche11, K. F., Steplewsiki, Z., Koprowski, A. A monosialoganglioside is a nonoclonal antibody deflned antigen of coloncarcinoma. Science; 212 ; $55-56,1981$

Magnani, J.L., N1 son, B., Brockhaus, M., Zopt, D., Steplewski, Z., Koprowsti, H., Glneburg, Y. A monowlonal antibody-defined antigen asgoclated with gastrolntestinal cancer in ganglioside contalning walytated lacto-N-fuco pentaose IT. A. Biol. chem.; $257: 14365-14369$, 1982

Magnani, J.L., Steplewsk, Z. Koprowsk, H* Ginsburg, W. The gastrolntestimal and pancreatic cancer-associated antigen detected by monocional antibody $19 / 9$ in the sera of patients is a mucin. In press, 1984

Marchand, A., Fenoglio, C.M., Pascal, R., Richart, R.M., Bennett, S. Carcinoenbryonic antigen $\mathbb{t n}$ human ovarian neoplasms. Cancer Res,; 35 : $3807-3810,1975$

Mason, D.Y., Taylor, C.R. The distribution of muramidase (1ysozyme) in human tissues. J. Clin. Patholl.; 28: 124, 1975

Hepham, B.L., frater, W., Mitchel, B. The use of proteolytic enzymes to improve Ig stainimg by the PAP technique. Histochem. J.; 11: 345-351, 1979

Mitchell, K. A A carcinoembryonic antigen (CEA) specific monoclonal hyrldoma ant body that reacts only with high-molecular-weight CEA. Cancer Immonol. Immonother.; 10: 1/5, 1980

Myauchi, T., Xonezawa, S., Takamura, T., Chiba, T., Tejima, S., Ozawa, M. , Sato, E., Muramatsu, T. A few fucosyl antigen expressed in colon adenocarcinoma and embryonal carcinoma cells. nature; 299 : 168-169, 1982

Montero, C., Segura, D.T. Retrospective histochemical study of mucosubstances in adenocarcinomas of the gastrointestinal tract. Histopathology; $4: 281-291,1980$

van Nagell, J.R., Jr., Donaldson, E.S., Gay, E.C. et al. Carcinoembryonic antigen in carcinoma of the weerine cervix. 2. Tissue Loca1.jation and correlation with plasma antigen concentration. Cancer; 44 : $944-948,1979$

Nakane, P.K., Plerce, G.B. Enzyme labeled antibodies: preparation and application for the locallzation of antigens. J. Histochem.cytochem.; $14: 929-931,1966$

Nap, M." Ten Hoor, K. A., Fleuren, G.J. Crossureactivity with normal antigens in commercial ant 1 -CEA sera used for immunohistology the need for tissue controls and absorptions. An.d.Clin.Pathol.; 79: 25-30, 1983

O'Briar D.S., Dayal, Y., DeLeilis, R.A., Tischler, A.S., Bendon, R., 
Wolfe, H.j. Rectal carcinoids as tumours of the hlndgut endocrine cells. Al. J. Surg. Pathol.; $6: 131-142,1982$

O'grien, M.J., Zamcheck, N., Burke, B. Kirkhar, S.E., Saravis, C.A., cottlieb, L.S. Inmunacy tochemical localization of carcinoenbryontc antigen in benign and malignant colorectal tissue. An. J. Clin. Pathol.: $75: 283-290,1981$

O"Daly, J.A., Graig, S.W., Cebra, J.J. Localization of b markers, alpha-chain and SC of sIgA lin epithelial cells lining Lieberkuhn crypt:s. J. Itamuno 1.; 106: 286-288, 1971

Ordronneau, P. Petrusz, P. Imnumocytochemical demonstration of anterior pituitary hormones in the pars tuberalis of long-term bypophysectomized rats. Am.J. Anat.; 158: 491-498, 1980

Pant, K.D., Dahlman, J.L., Goldberg, D.M. Further Characterization of CSAP, an antigen associated with gastrointestinal and ovarlan tumours. cancer; $42: 230-238,1978$

P.arada, L.F., tabin, C.J., Shith, C., Welnberger, R.A. Hum EJ bladder carcinoma oncogenes is homologue of Harvey sarcoma virus ras gene. Nature; $297: 474-478,1982$

Pascal, R.R., mesa-Tejada, R., Bennett, S.J., Garces, A., Fenogllo, C.M. Carcinoembryonic antigen. Immunohistologlc ldentfication in invasive and Intraepthelial carctnomas of the lung. Arch.Pathol. Lab. Med.; 101: $568-571,1977$

Paulie, S., Hansson, X., Lundblad, M.L., Perlmann, P. Lectins as probes for Identification of tumour-associated antigens on urothelial and colonic carcinoma cell lines. Int. J. Cancer; 31: 297-303, 1983

Pearse, A.G.E. In: Histochemistry-Theoretical and applied; $1,3 \mathrm{rd}$ Ed. Churchill Livingstone, 1968

Peeters, T., Vantrappen, G. The Paneth cell: a source of intestinal Iysozyme. Gut; 16: 553,1975

Peatycross, $C . R$. The Tennessee antigen test. An evaluaton 1 n cancer and non-cancer patients and normal subjects. Br.J.Cancer; 45: 223-229, 1982

Persijn, J.P., hart, A.A.M. Prognostic signiflcance of CEA in colorectal cancer: a statistical study. J. Clin. Chem.Clin.Blachem.; 19: 1117-1123, 1981

Peterson, S.E., Blchel, P., Lorentzen, M. Flow-cytometric denongtration of tumour cell subpopulations with dfferent DNA content in hum colorectal carcinoma, Eur. J. Cancer; 15; 383-386, 1978

Plhi, E*, Malrn, R.C., Hughes, E.S. Cumberson, A.M., Rollo, A.d. Mucinous colorectal carcinoma: inmunopathology and prognosis. Pathology; $12: 439-447,1980$ 
Podolsky, D.K. Welgser, M.M., Ieselbacher, K.J. et al. A cancer-assoclated galactovyltransf́rase 1soenzme. N. EngI.J.Med.; $299: 703-705$, 1978

Poger, M.E., Hisch. B.R., Lam, M.E. Synthesls of secrecory component by colonde neoplasm. An. J. Pathol.; 82: 327-338, 1976

Pollack, M.S., Heagney, S.D., Livingstone, P.O., Fogh, J. HLA-A, B, C and Wh alloantigen expregsior on forty- $1 \times$ cultured hum tumour cell 11 nes. JMCI. $66: 1003-1012,1981$

Poste, G. Cellular heterogenelty in mallgnant neoplasws and the therapy of netastases. Annals New York Academy of Science, 1982

Potter, T.P., Jordan, J.D., Jordan, T.A. Compendium of Assays for Inmunodlagnosis of human cancer. (Herberman, Ed.). Elsevier Nor th-Holland, Ine.; 217-224, 1979

Prehm, R.T., analysis of antigenic heterogenelty within individual 3-methylcholanthrene-induced mouse sarcomas. J. Natl. Cancer Inst.;45: $1039-1045,1970$

PrImus, B.J., Newell, K.D., Blue, A*, Goldenberg, D.M. Immunological heterogeneicy of carctnoembryonic antigen distingulished by monoclonal antibodies. Cancer Res.; $43: 686-692-1983 a$

Primus, F.J., Kuhns, W.J., Goldenberg, D.M. Immunological heterogenelty of carcinoembryonic antigen: immunohistochemical detection of carcinoembryonic antigen determinants in colonic tumors with monoclonal antibodies. Cancer Res.; 43: 693-701, 1983b

Pulclan1, S., Santos, E., Lauver, A.V., Long, L.K., Stuart, A., Barbacid, A. and M. Oncogenes $\mathrm{ln}$ solid human tunours. Nature; 300 : $539-542,1982$

Pusztaszeri, G., Saravis, C.Am, Zamcheck, N. The zinc glycinate marker in human colon carcinoma. JMCI; 56: 275-278, 1976

Qualheim, R. E, Gall, E.A. Is histologic grading of colon carcinoma a walld procedure? Arch. Pathol.; 56:466-472, 1953

Rapp, W., Windish, M., Peschke, P., Wurster, K. Purlfication of human intestinal Goblet cell antigen (GOA), its inmonohistological demonstration in the intestine and in mucus producing gastrolntestinal adenocarcinomas. Virchows Arch.; $382: 163-177,1979$

Raux, H., Labbe, F*, Fondaneche, M. C., Koprowsk1, H., Burtin, P. A study ogf gastrolntestlnal cancer-associated antigen (GICA) in hum fetal organs. Int.J.Cancer; 32: 315-319, 1983

Rechavi, G., Givol, D., Caamani, E. Activation of a cellular oncogene by DNA rearrangement: possible tnvolvenent of an IS-like element. Nature;

$300: 607-611,1982$ 
Rees, H.W., Irie, R.F., Morton, D.L. Oncofetal antigen-1: distribution in human tumors. JNCI; $67: 557-562,1981$

Ragers, G.T. Heterogeneity of carcinoembryonic antigens: Implications on its role as a tumour marker substance. Blochim Blophys. Acta; $458: 355$, 1976

Rogers, G.T*, Rawlins, G.A., Bagshawe, K.D. Somatic-cell hybrids producing antibodies agalnst CEA. Br.J. Cancer; $43: 1 / 4,1981$

Rogers, G.T Carcimoembryonic antigens and related glycoproteins molecular aspects and specificity. Biochim.Blophys.Acta; 695; 227-249, 1983

Rogntu, "T.0., Brandtzaeg, P., Orjasaeter, H., Eligjo, K., Hognestad, J. Imunohistocherical study of secretory component, secretory IgA and carcinoembryonic antigen in large bowel carcinomas. Pathol. Res. Pract.; $170: 126-145,1980$

Rognum, T.0., Elgjo, R., Brandtzaeg, P., orjasaeter, H., Bergen, A. Plasma carcinoembryonic antigen concentrations and inmunohistochemical patterns of eplthelial marker antigen in patients with large bowel carcinoma. J. Clin. Pathol.; 35: 922-933, 1982

Rutzky, L.P., Sictiliano, M.J. Various isoenzyme gene expression patterns among human colorectal adenocarcinoma cell Ilnes and tissues. JNCI; 68 : $810-90,1982$

Sallen, S.E., Ritz, J., Pesando, I., Geibar, R., 0'Brien, C., Hitchcock, S., Coral, F., Schlossman, S.F. Cell surface antigens:: prognostic implications in childhood acute lymphoblastic leukemia. Blood; 55: 395, 1980

Santos, E. Trontck, S.R., Aaronson, S.A., Pulciani, S., Barbacld, M. T24 human bladder carcinoma oncogene is an activated form of the norma 1 human homologogue of BALB- and Harvey-MSV transforming genes. Narure; $298: 343-347,1982$

Schmeche1, D., Marangos, P.J., Brightman, M. Neurone specific enolase is a molecular marker for peripheral and central neuroendocrtne cells. Nature; $276: 834-836,1978$

Sevier, A. Munger, B.C. A silver method for paraffin Bections of neural tissue. J. neuropathol.Exp.Pathol.; $24: 130,1965$

Shevchuk, M.M., Genoglio, C.M., Richart, M. Carctnoembryontic antigen localization in bendgn and malignant epthellum. Cancer; 47: 899-905, 1981

Shik, C., Shilo, B.Z., Goldfarb, M.P., Dannenberg, A., Weinberg, R.A. passage of phenotypes of chemically transformed cells wa transfection of DNA and chromatin. Proc.Nat1. Acad.Sci. USA; 76: 5714-5718, 1979

Shimizu, K., Goldfarb, M., Suard, Y., Perucho, M., L1, Y., Kamata, T. 


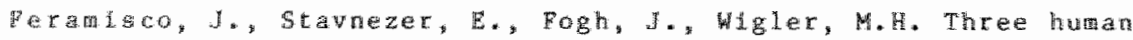
trangorning genes are celated to the wral ras oncogenes. HOC,Nat I. Acad.Se1.; 80: 2112-2115, 1983

Shochat, D., Archey, R.L., Part, K. D., Dahlman, H.L., Gold, D.V., coldemerg, D. Characterization of colon-specticic antugen-p and lsolation of inmunolog tcally active tryptic peptides. I. Inmunol.; 126: $2284-2289,1.981$

Shoubha, S., Lyestotis, T. Correlation of carcinoembryonic antigen in thesue sections with spread of mandory carcinoma. Histopathology; 2: $433-447,1978$

skinner, J.M., Whtehead, R. Tumor-assoctated antigens in polyps and carkinoma of the human large bowel. Cancer; $47: 1241-1245,1981$

Sloane, J.P. Ormerod, M.G. Distribution of epithelial membrane antigen in mormal and neoplastic tissues and its value in diagnostic tumour pathology. Cancer; 47: 1.786-1.795, 1981

Splcer, S.S. planine methods for differentiating mucosubstances histochemically. I. Histochem. Cytochem.; 13:211-234, 1965

Spremuli., E.N., Scott, C., Campell, D.E., Libbey, P.L., Shochat, D., Cold. D.V., Dexter, D.L. Characterization of two metastatic subpopulations orighating from a single human colon carcinoma. Cancer Res.; $43: 3828-3835,1983$

Staab, H.J., Anderer, F.A., Hesche, K., Wehrle, E., Rodatz, W. Is gerum beta 2-microglobulin a tumor matker in gastrointestinal cancer, Clin.Chin.Acta; 1.06: 309-317, 1980

Stoward, P.J., Splcer, S.S., Miller, R.L. Histochentcal reactivity of peanut lectin-horseradish peroxidase conjugates. J. Histochem. Cytochem : 28: $979-990,1980$

Stranignoni, D., Bowen, R., Atkinson, B.F., Schlom, J. Differential reactivity of monoclonal antibodies with human colon adenocarcinomas and adenomas. Int. J. Cancer; $31: 543-552,1983$

Straus, W. Imidazol lacreases the sensitivity of the cycochemical reaction for peroxidase with diamobenzidine at neutral pH. J. Hitstochen, Cy tochem, ; $30: 491-493,1982$

Svenberg, T., Hammatstrom, S., Hedin, A. Purification and properties of billary glycoprotefn 1 (BGP). Imnunochemical relationship to carcinom ambryonlc antigen. Mol. Immunal.; 16: 245-252, 1979

Symonds, D.A. Pameth cell metaplasia in deseases of the colon and sectum. Arch. Pathol. 97:343, 1974

Symonds, D.A. Vickey, A.L. Muelnous adenocarcinoma of the colon and rectum. Cancer; $37: 1891-1900,1976$ 
Szuman, E.A. The histological distribution of the blood group substances in wan as disclosed by immortuorescence. III the A, B and H antigens in embryos and fetuses from 18 tm, in lemth. J. Exp. Med.; $119: 503-516,1964$

Taub, R., Kirsch, I. Marton, C. et al. Translocation of the cumyc gene into the Immunoglobulin heavy chain locus in human Burkin lymphoma and furine plasmacytoma cel1s. Proc.Natl.Acad.Sci.; 79:7837-7841, 1982

Taxy, J.B., Mendelsohn, G., Gupta, P.K. Carcinold tumours of the rectum. Am. J. Clin. Pathol.; 74:791-795, 1980

Taylor, C.R. Immonoperoxidase techniques. Arch. Pathol.llab.Med.; 102 : 1978

Taylor-Papadimitriou, J., Peterson, J.A., Arklie, J., Burcha11, I., Ceriani, R.L., Bodmer, H.F. Monoclonal antibodies to eplthelium specific components of the human milk fat globule membrane; production and reaction with cells in culture, Int. $\mathbb{J}$. Cancer; $28: 17-21,1981$

Thompson, C.H., Jones, S.L., PHi, E., Mckenzie, I.F.C. Monoclonal antibodies to human colon and colorectal carctnoma. Br. J. Cancer; 4 : $595-605,1983$

Tourvile, D.R., Adler, R.H., Blenenstock, J., Tomasi, T. B. The hurin secretory immunoglobulin system: immonohistological localization of A, secretory "plece" and lactoferrin in normal hum cissues. I. Exp. Med.; $129: 411-426,1969$

Trimpi, H.D., Bacon, H. E. Mucold carcinoma of the rectum. Cancer; 4 : $597-609,1951$

Tsukimoto, I., Wong, K.Y., Lampkin, B.C. Surface markers and prognostic factors in acute 1ymphoblastic leukemia. N. Engl.J. Med.; 294: 245-248, 1976

Ulich, R. I., Chang, L., Glover, H., Yang, K., Lewin, K.J. A colonic adenocarcinoma with argentafin cells. An immonoperoxidase study demonstrating the presence of numerous neuroendocrine products. Cancer; $51: 1483-1489,1983$

Whdelov, L.L., Hansen, H.H., Christensen, I.J. Clonal heterogenelty of smal-cell amaplastic carcinoma of the lung demonstrated by flow-cytometric DNA analysis. Cancer Resw; 40:4295-4300, 1980

Vrba, R., Alpert, E., Isselbacher, K.J. Carcinoembryonic antigen: Evidence for mulliple antigenic determinants and soantigens. Proc. Nat 1.Acad.Sc1.; $72: 4602-4609,1975$

Wagener, C., Joy Yang, Y.H., Crawtord, F.G., Shlvely, J.E. Monoclonal antibodies for carcinoembryonic antigen and related antigens as a mocel system: a systematic approach fior the deternination of epitope spectficities of monoclonal antibodies. J. Immunol: $130: 2308-2315,1983$ 
Halker, R.A. Wucold carcinomas of the breast: a study using aucin histochenlatry and peanut lectin. Histopathology; 16:571-580, 1982

Whatis, A.J., Roy, A.D. Paneth cells in the large intestine in ulcerative colitis. J. Patt. Bact.; $80: 309,1960$

Weinberg, R. A. Use of tranfection to analyse genetic information and mallgnant transformation. Riochem. Blophys. Acta: 651:25-35, 1981

He 1sz-Carrington, P., Poger, M.E., Lamm, M.E. Secretory Imnuthoglobullns in colonic neoplasmis. An. I. Pathol.; 85: 303-316, 1976

West, K.P., Platts, H.A., Fletcher, A., Walker, F. Tissue carbohydrate tdertiflcation by the use of lectins. J. Clin.Pathol.; 35: 239-240, 1982

W1llighagen, R.G.J. Histochemistry in pathologic diagnosis. Beler.Pathol.; 141: 280,1970

Wolman, E.F., Ostler, V.B, Collen, T.A. Mucoid adenocarcimoma of the color and rectum. Surgery; $42: 846-852,1957$

Woodruff, M.F.A. Cellular heterogenelty in tumours. Br. J. Cancer; $47:$ $589-594,1983$

Yang, K., Ulich, T., Cheng, L., Lewin, K.J. The neuroendocrine products of intestinal carcinoids. Cancer; $51:$ 1918-1926, 1983 


\section{Chapter II}

DISTRIBUTION OE MONOCLONAL ANTIBODY-DEEINED MONOSIALOGANGLIOSIDE IN NORMAL AND CANCEROUS HUMAN TISSUES: AN IMMUNOPEROXIDASE STUDY

J. W. Arends, C. Verstijnen, F. T. Bosman, J. Hilgers and $Z$. Steplewski.

\subsection{Summary}

The immunoreactivity of a monosialoganglioside antigen defined by monoclonal antibody 1116 NS19-9 (19-9) was studied in neoplastic and normal glandular and mucosal epithelia using an indirect immunoperoxidase method. In neoplastic mucosae, the antigen was detected in the majorlty of colorecta 1 and endometrial carcinonas, predominantly in a Eocal staining pattern. A substantial proportion of gastric and pancreatic tumours and an occasional breast carcimama also reacted with the monoclonal artibody. Expression of the monosialoganglioside in nomal colonic mucosa appeared to be restricted to areas adjacent to tumour tissue. In gastic mucosa the antigen was confined to some areas showing intestinal metaplasia. The antigen was also detected in the epithelium of normal mucosa of the gall bladder and endocervix, as well as in some ducta 1 epithelia of the pancreas and salivary glands. Most other mucosae were negative for antigen expression.

Published in: Hybridoma, 2: $219-229,1983$ 
Monocional antibodies against colon carcinoma were first reported by koprowski et al. (1979). The binding to colon carcinome cells of one of these monoclonal antibodies was inhibited by sera from patients with adenocarcinoma of the colon, stomach, and pancreas, but not by sera from patients with othet bowel diseases or from healthy individuals (koprowski et a I., 1981). Furthermore, the antibody did not react with carcinoma cell Iines other than colorectal (koprowski et al, 1979). The target antigen was subsequent$1 y$ defined as a monosialoganglioside (Magnani et al. "IgBl), which was demonstrable in colorectal carcinoma tissue and meconium only. Because the antigen appeared to retain sufficient immunoreactivity after routine fixation and tissue processing procedures, it became possible to determine its distribution and precise tissue localization in different organs by means of an immunoperoxidase technique.

we report here the results of the immunoreactivity assays of this monoclana 1 antibody-defined monosialoganglioside in adenocarcinoma and in fetal and adult glandular ti. wsues.

The antigen is not restricted to oncofetal tissues, as it can be detected in normal adult epithella af gall bladder, endocervix, pancreas, salivary glands, and colon. Most colonic adenocarcinomas and other adenocarcinomas of the endometrium, pancreas, and stomach demonstrated the antigen. staining of normal. colonic mucosa was restricted to areas adjacent to tumour tissue.

\subsection{Material and methods}

2.3.1. Monoclona 1 antibody

"The hybridoma $1116 \mathrm{NS}$ 19-9 (19-9), which secretes an antibody against the swl116 colon carcinoma cel1 line, was established after fusion of immune splenocytes with the 653 variant of $\mathrm{P} 3 \times 63 \mathrm{Ag} 8$ myeloma cells.

\section{3 .2 . Tissues}

The immunoreactivity of the 19-9 antibody was tested on paraffin sections, Eixed in 4 neutral buffered formalin of the following human tissues: a panel of adenocarcinomas (Table 1), a total of 17 fetal intestinal mucosa from 12-40 week fetuses (kindly provided by Dr. J. Muber. Professor of Pediatric Pathology, State University, Utrecht, The Netherlands); and normal adult glandular and mucosal epithelia (Table 2).

\subsubsection{Immunocytochemistry}

Initially, to determine the influence of routine tissue processing procedures on the immunoreactivity of the antigen, the staining patterns of frozen sections postfixed in 
acetone (10 min at 4 c) and of formalin fixed and paraffinembedded tissue sections of the same tumour were compared. Paraffin-embedded tissue sections $(5 \mathrm{~m})$ were then deparaffinized, rehydrated, and blocked for endogenous peroxidase activity by incubation in a 0.5 solution of hydrogen peroxide in methanol. After incubation in a 0.18 trypsin solution (sigma chemical Company) in $0.1 \mathrm{CaCl}$, (pH 7.8 ) for 25 min at $37 \mathrm{C}$, sections were incubated with normal rabbit serum (1:5) for 10 min and then with 19-9 monoclonal antibody for $30 \mathrm{~min}$. The optimal antibody dilution for parafin sections was found to be 1.256; the antibody was used unciluted for frozen sections. Sections were then exposed to peroxidase-labeled rabbit anti-mouse Ig (DAKO, code no. p161) (1:50) for 30 min. All dilutions were made with 2.5 . normal human serum in Tris buffer (pH 7.6). Each step was followed by washing in Tris buffer (three changes in 5 min!. Finally the sections were developed with diamobentidine and counterstained with hematoxylin.

\section{4. Results}

The distribution of the monoclonal antibody-defined monosialoganglioside did not appear to be different on mildiy fixed frozen as compared with formalin-fixed, paraffin embedded sections of the same tissues, when the antibody was applied undiluted on the former and used after trypsinization on the latter. When diluted monoclonal antibody was applied on frozen sections or undiluted antibody was used on nontrypsnized paraffin sections, no consistent pattern of staining was obtained.

\subsubsection{Adenocarcinomas}

Thirty-eight of 54 (70\%) of colorectall adenocarcinomas of the colorectum and eight of 11 (73) endometrial adenocarcinomas reacted. with 19-9 antibody. Seven of 13 (548) gastric and two of three pancreatic adenocarcinomas also reacted with antibody $19-9$ (Table I). One of two gall bladder carcinomas and only one of 10 breast carcinomas were reactive. The two carcinomas of prostate and two of kidney tested were negative for the presence of the antigen. The majority of adenocarcinomas of the colorectum (Eig. 1) and endometrium (Eig. 2) reacted with the 19-9 antibody. predominanty as a focal staining of apical cell borders and secretion products in glandular tumour formations. In some tumours, cytoplasmic dots were occasionally observed. Ademocarcinomas of the pancreas (Fig. 3), stomach (Fig. 4), and gall bladder, as well as one case of breast carcinoma (Fia. 5) showed a focal reaction product in glandular formations. 


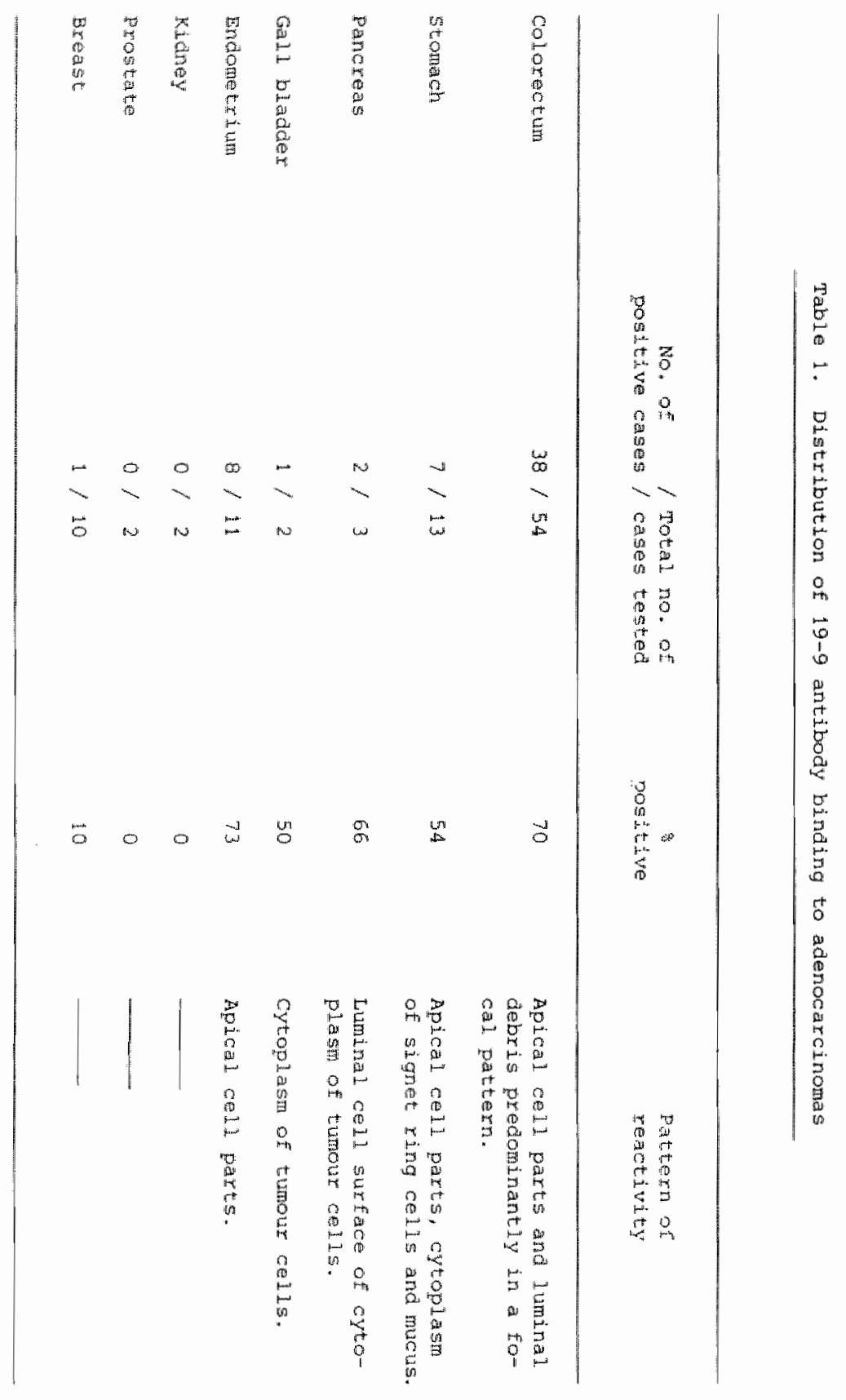




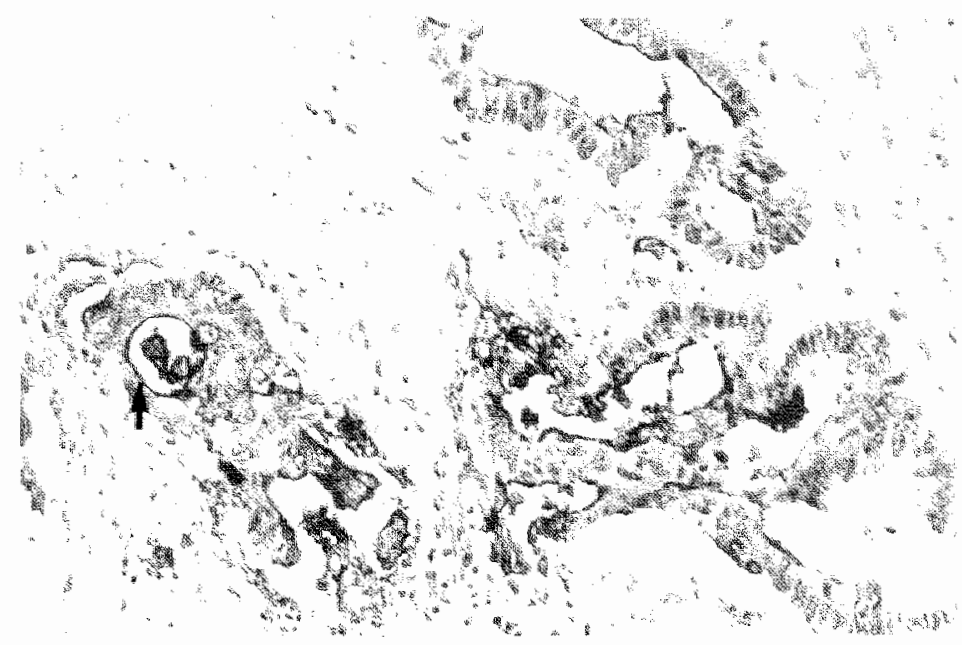

Fig. 1. Colonic adenocarcinoma, a reaction product at the luminal cell border (atrow), \$125.

\subsubsection{Adult glandular and mucosal epithelial}

The results of the immunoperoxidase assay for the detection of the antibody 19-9 defined antigen in adult glandular and mucosal epithelia are summarized in Table 2. Twelve of 20 (608) colorectal mucosa specimens and five of 10 (508) gastric mucosa specimens showed positive staining with the 19-9 antibody only in areas adjacent to the tumour. Endocervical mucosa and salivary gland ductal epithelium were also positive, and in three of four pancreas specimens ductal epithelium and in six of seven gall bladder specimens mucosal epithelium also showed staining. Normal kidney, prostate, and breast were all negative for the antigen. Normal large intestinal mucosa showed no staining. Immunoreactivity detected in normal colonic epithelium in cancer containing specimens was confined to areas adjacent to the tumour, and appeared ither as weak staining of the apical cell surface (Fig. 4A) or as strong cytoplasmic staining of some goblet cells in the crypt lining epithelium (Fig. 4B). Breast, prostate, and renal cortex epithelia did not show immunoreactivity with the antibody. Gastric eplthelium only stained in areas of intestinal metaplasia or in the immediate vicinity of a tumour. Columnar cells in endocervical mucosa (Fig. 5), salivary gland ductal epithelium (Fig. 6), and pancreas showed marked immunoreactivity, particularly the gall bladder epithelium, which consistently showed intense staining ( $F$ ig. 7). A focal staining pattern was generally observed in these tissues. 


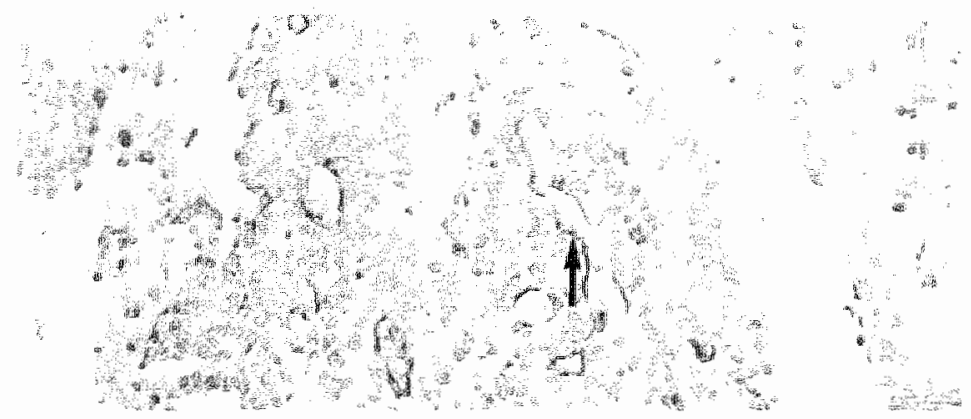

F1g. 2. Adenocarcinoma of endometrium, $\times 200$.

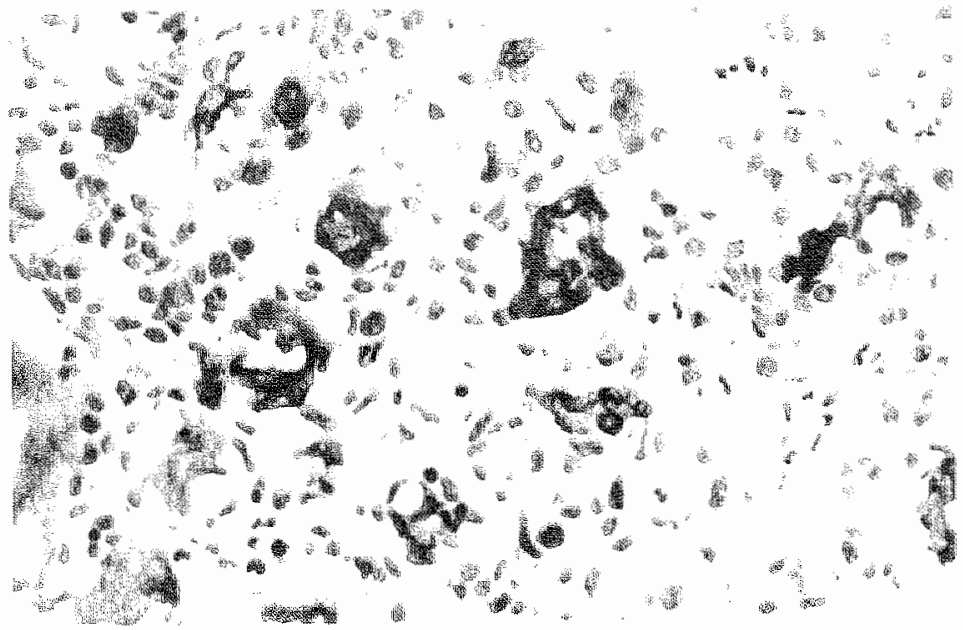

Filg. 3. Adenocarcinoma of pancreas, x 200. 


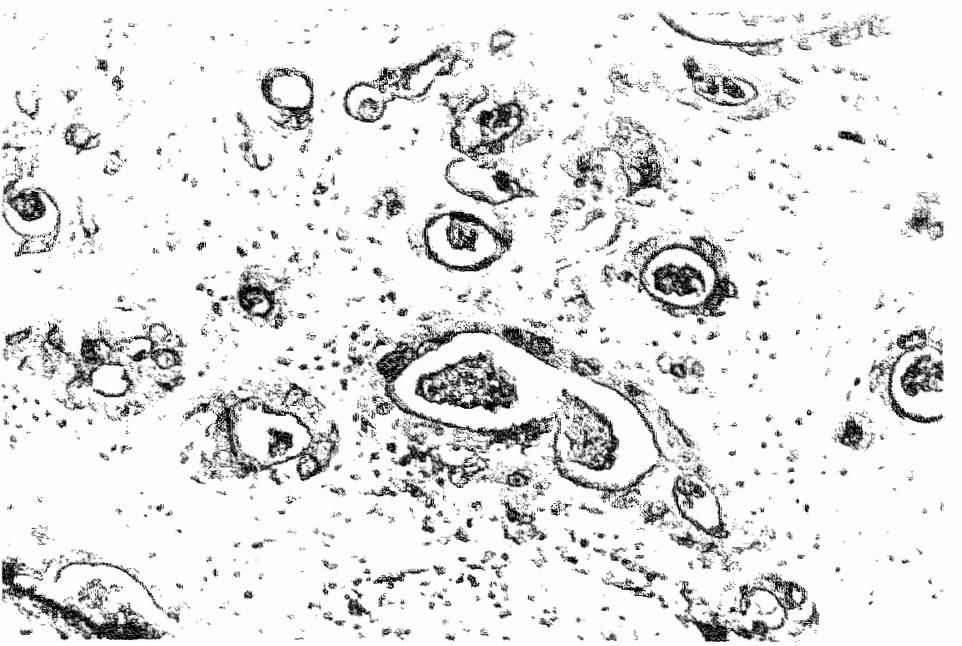

Fig. 4. Adenocarcinoma of stomach, $x 125$.

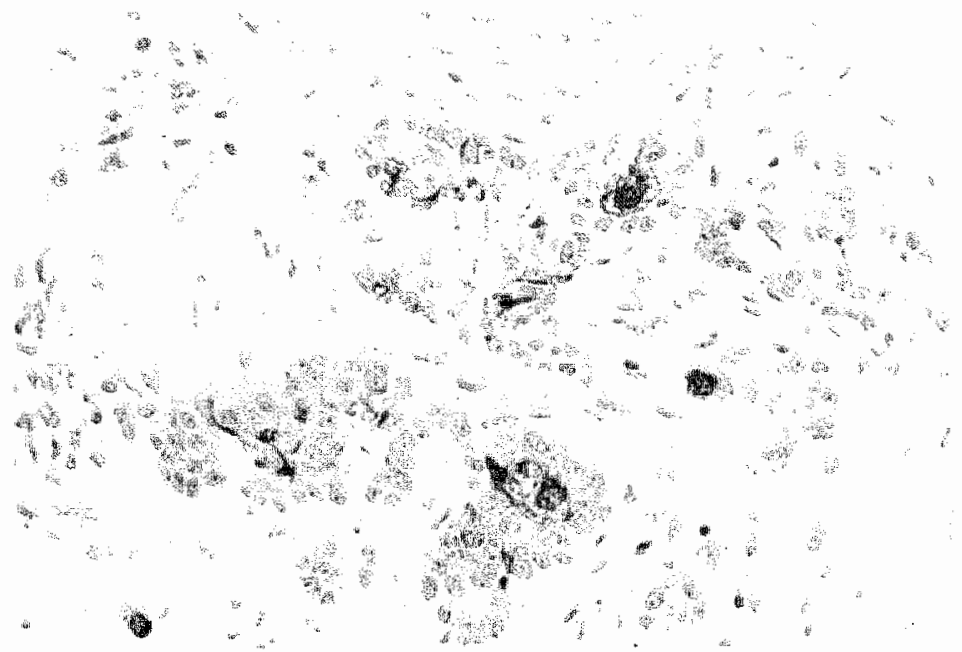

Fig. 5. Adenocarcinoma of breast, $x 200$. 


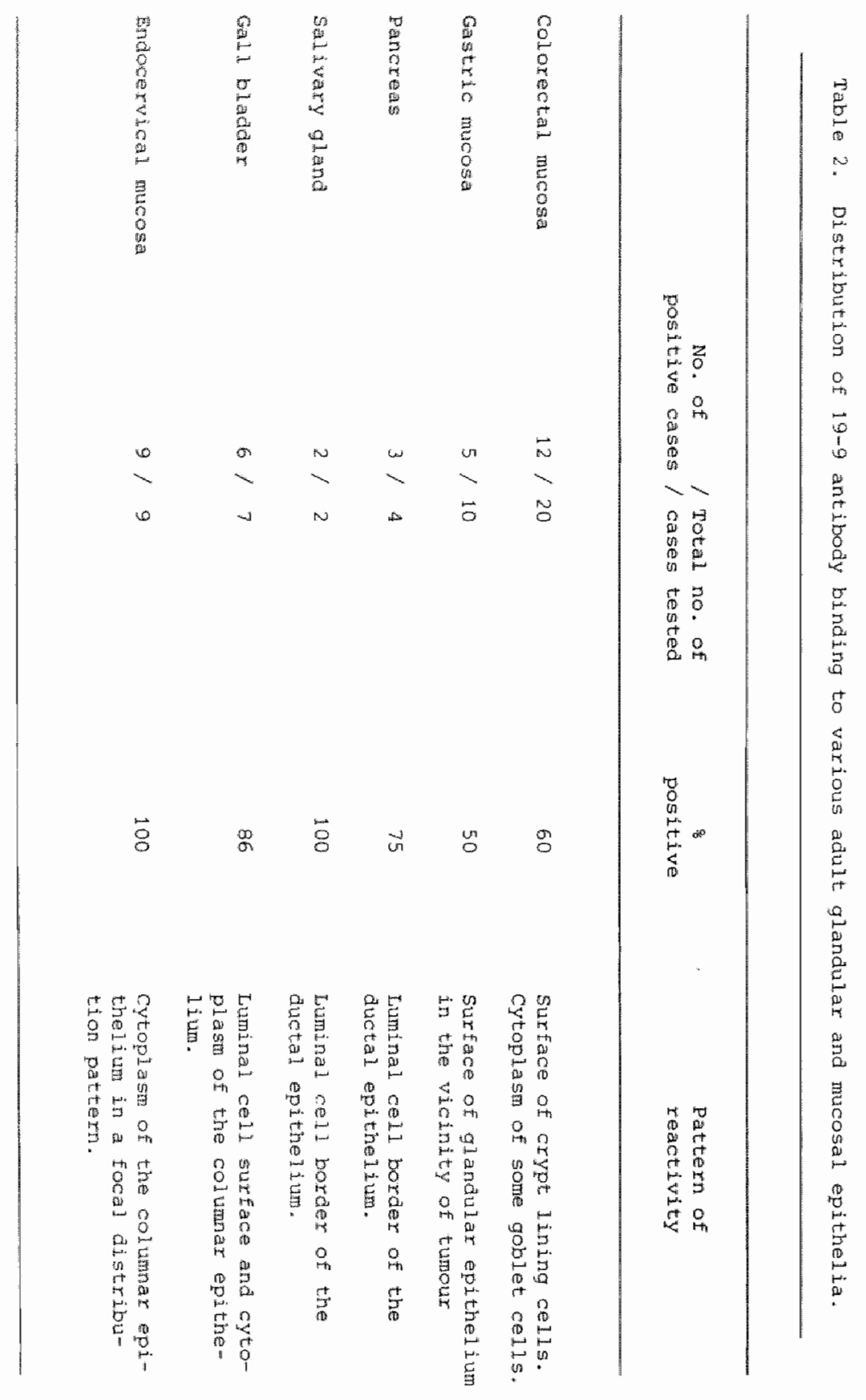




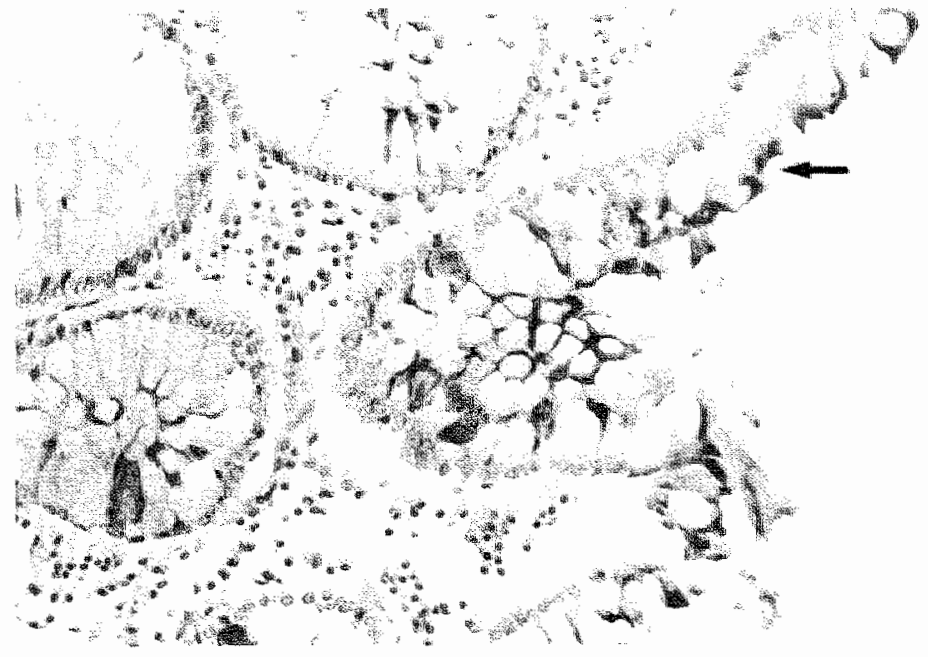

Fig. 6. Colonic mucosa adjacent to adenocarcinoma. A staining of the apical cell border is to be seen, $\times 200$.

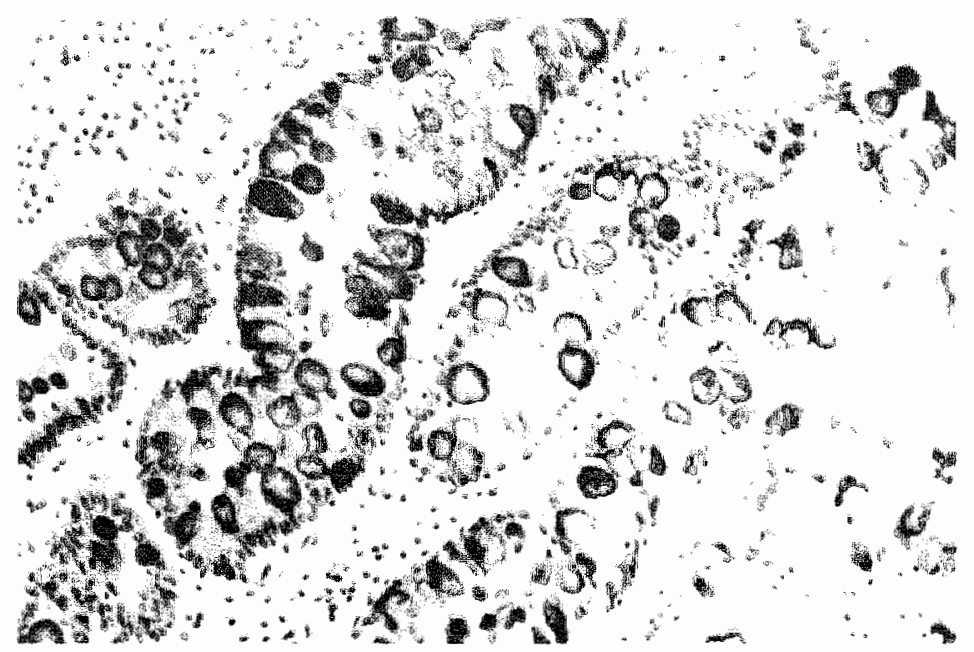

Fig. 7. Colonic mucosa adjacent to adenocarcinoma. In this case multiple reactive goblet cells are observed, $x 200$. 


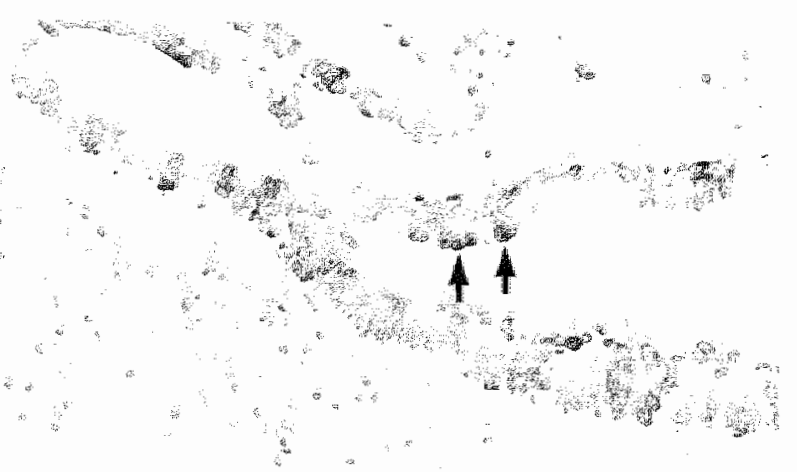

F1g. 8. Momal endocervical glandular mucosa. Note the focal distribution pattern and a cytoplasmic staining reaction (arrow), 200 .

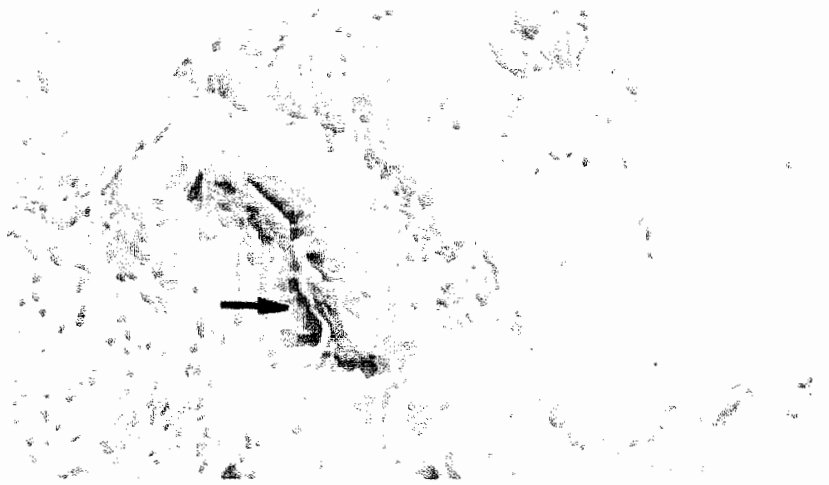

Fig. 9. Duct of normal salivary gland with a reaction product at the luminal cell border of the lining epithelium (arrow), $\times 125$.

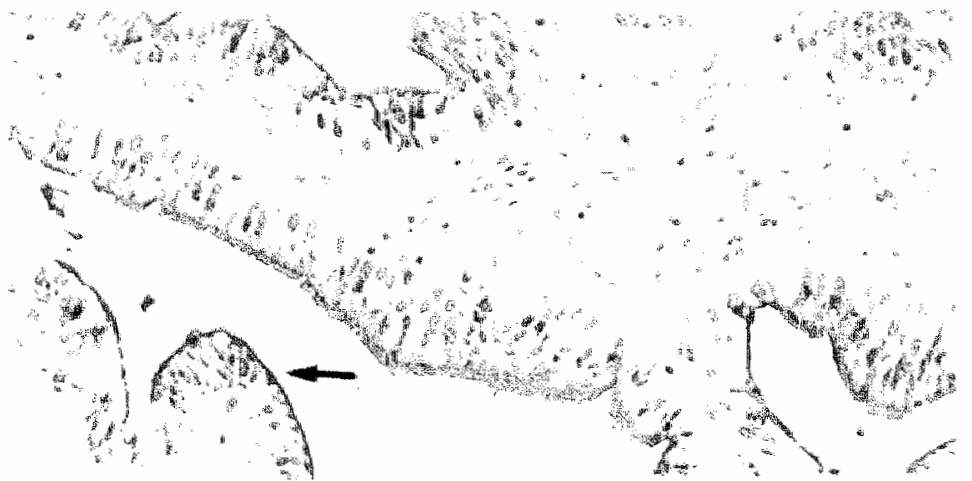

1.g. 10. Normal mucosa of gall bladder with a staining of the apical cell border, $\times 200$. 
2.4.3. Fetal intestima1 tissue

Goblet cells of intestinal mucosa of 12-week ambryos were positive for the $19-9$ defined antigen, showing a moderate staining intensity (Fig. 8A). In later stages of gestation, the antigen was also expressed on the brush border of the columar epithelium in the small and large bowel (Fig. 8bi).

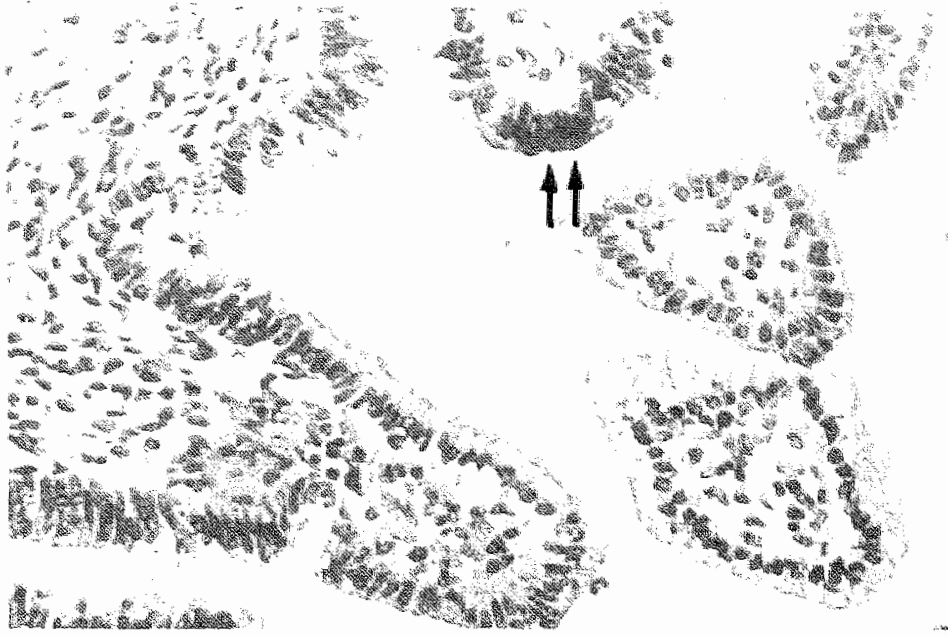

F1g. 11. Fetal intestinal mucosa of 12 whs. Note a few moderately stained goblet cells (arrow) in the superficial mucosa, x 200 .

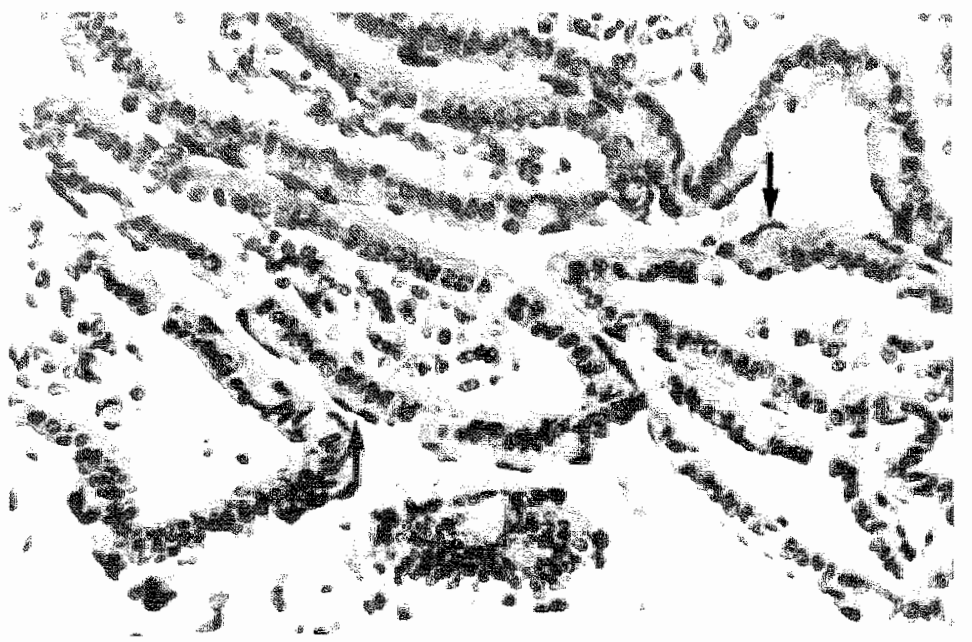

Fig. 12. Fetal intestinal mucosa of 22 wks. The reaction product is located at the 1 uminal cell surface (atrows), $x 125$. 
The Iy-9 monoclonal antibody against colonic carcinoma was originaly described as weactive only with colorectal carcinoma cells, and not with normal colonic epithelium or with carcinomas other than of the colon (Koprowski et a 1. 1979). It was also demonstrated that binding of this antibody to SW1LL6 colon carcinoma cells was inhibited by sera from patients with adenocarcinoma of the colon, stomach, and pancreas, but not by sera from patients with non-neoplastic intestimal disease or from heallhy individuals (Koprowski et a 1., 1981; Hexlyn et a 1., 1982). Finally, the target antigen w identified as a monosialoganglioside, which could be detected in colocectal carcinoma tissue and meconium only (Magnami et a 1., 1981 ) and which showed no immunologic similarity to carcinoembryonic antigen (CEA).

These experimental data suggested that the antigen might be oncofetal and potentially useful for the detection of collorectal carcinoma. We decided to perform a systematic survey on the distribution of the antigen in various tissues, using an immunoperoxidase method. Tissue sections rather than cultured cells were chosen, because they play a substantial role in the selection and characterization of monoclonal antibodies with a desiced specificity (Finan et a 1., 1982). The results indicate that the target antigen is not oncofetal, since it was detected in differentiated normal adult glandular epithella, such as endocervix, gall bladder, pancreas, and salivary gland. The distribution of the antigen in mildly fixed frozen sections closely parallelied that in trypsin treated sections, excluding the possibility that antigenic properties were altered by routine tissue processing methods. Thus the discrepancies between results of tests on cell lines and on tissue sections cannot be explained by differences in the techniques used. The antigen, however, does appear to be present abundantly in most colorectal and endometrial adenocarcinomas, whereas it is absent or almost absent in normal mucosae as shown also by Atkinson et a 1., (1982). In adult colonic mucosa the antigen appears to be localized only in areas adjacent to tumour tissue, either weakly staining the luminal surface of crypt lining celis, which could be the result of shedding of antigenic material into the surrounding tissue (Koprowski et a 1. 1981), or strongly staining the cytoplasm of a few Coblet cells. The intense staining of the latter cells suggested that they might produce the antigen. In individuals with positive Le phenotype (Magnani et a1."1982; Koprowski et all., 1982, Steplewski et a 1.. 1983) the antigen would be expected to be represented in the salivary glands and their secretions since this particular monosialoganglioside represents a silalyated Le hapten Magnani et al., 1982; Koprowski et al., 1982; steplewski et al., 1983; Falk et a $1 ., 19831$.

The 19-9 target antigen appears to be more widely distributed than originally proposed. It is conceivable, how- 
ever, that it is present in such small quantities in tumour adjacent epithelium that it can only be detected using a very sensitive immunoperoxidase procedure. Eurthermore, cultures of cancer cells probably represent only a linited selection of the cells present in the original tumour and. in addition, may loose some characteristics of the original tumour during cultivation. For these reasons immunohistochemical studies of cancerous tissues should be considered an essential step in the final characterization of antitumour monoclonal antibodies.

The question remains whether the presence of the antigen in the vicinity of a tumour indicates a premalignant alteration of normal mucosal epithelium (Filipe, 1979) or a reaction to adjacent malignant cell proliferation (Isaacson and Attwood, 1979).

It is concelvable that the presence or absence of the 19-9 target antigen is related to the level of differentiation of colonic adenocarcinoma. This question is currenty under investigation. 
Atktnan, B.F., Ernst, C.S , Herlyn, M., Steplewskl, Z., Sears, H.F., and Koprowski, H. Gastrointegtinal cancer assoclated antigen in lmmoperoxidase assay. Cancer Res.; $42: 4820 m 4823,1982$

Falk, K.-E., Karlsson, K.-A., Larson, G., Thurim, Y., Blaszczyk, M. * gteplewski, $\mathbb{Z}$, and Koprowski, H. Mass spectrometry of a human tumor glycolipld antigen belng deflued by mouse monoclonal antibody NS-19-9. Blochen. Blophys. Res. Comin.; 110: 383-391, 1983

Hllpe, M.R. The value of a study of the mucosubstances in rectal biopgles from patients with carcinoma of the rectum and lower sigmoid in the diagnosis of prenalignant mucosa. J. Clin. Pathol.; 25: $123-128,1972$

Ilinan, P.J., Grank, R.M., De Matros, C., Takei, F., Berry, P.J., Lennox, E. S., and Bleehen, M.M. Immunohistochemical techniques $t \mathrm{n}$ the early screening of monoclonal antibodies to human colonic epithelium. Brit. I. Cancer; $46: 9-17,1982$

Herlyn, M., Sears, H.F., Steplewski, Z., and Koprowski, H. Monoclonal antibody detection of a clrculating tumor associated antigen. I. Presence of antigen in sera of patients with colorectal, gastric and pancreatic carcinoma. J. Clin. Immunol.; 2: 135-140, 1982

Lsaacson, P., and Attwood, P.R.A. Fallure to demonstrate specificlty of the morphological and histiochemical changes in mucosa adjacent to collonic carcinoma (transitional wucosa). J. Clin. Pathol.; 32:214-218, 1979

Koprowski, H., Brockhaus, M., Blaszczyk, M., Magnani, J., and Steplewski, 2 . Lewis blood-type may affect the incidence of gastrointestinal cancer. Lancet; 12: 1332-1333, 1982

Koprowsk1, H., Herlyn, M., Steplewski, 2., and Sears, H.F. Speclfic antigen in serum of patlents wh colon carclnoma. Science; $212: 53-55$, 1981

Koprowski, H., Steplewski, Z., Mitchel1, K., Herlyn, M., Herlyn, D., and Fuhrer, P. Colorectal carcinoma antigens detected by hybridoma antibodies. Som. Cell Gen.; 5: $957-972,1979$

Magnani, J.L., Brockhaus, M. "Smith, D.F., Ginsburg, V., Blaszczyk, M., Mitchell, K.F., Steplewsk1, Z., and Koprowsk1, H. A monosialogangllosde 1 a monoclonal antibody-defined antigen of colon carcinoma. sictence; $212: 55-56,1981$

Magnani, J., Nilsson, B., Brockhaus, M., Zopf, D., Steplewsk1, Z., Koprowskl, H., and GInsburg, $V$. A monoclonal antibody-defined antigem assoctated with gastrointestinal cancer is a ganglioside containing sialyted Lacto-N-fucopentaose II. J. B101. Chem.; 257: 14365-14369, 1982

Steplewsk1, Z., Herlyn, M., Blaszczyk, M., and koprowsk1, H. A simple procedure for determinfing Lewilis phenotyes in human saliva. J. Tmmunol. Meth.; in press, 1983 
MONOCLONAL ANTIBODY (1116 NS 19-9) DEFINED MONOS IALOGANGL IOSIDE (GICA) IN COLORECTAL CARCINOMA IN RELATION "TO STAGE, HISTOPATHOLOGY AND DNA FLOW CWTOMETRY.

J.W. Arends, T. Wiggers, B. Schutte, C.T. Thijs, C. Verstijnen, J. Hilgers, G.H. Blijham and E.T. Bosman .

3. 1. Summary

Immunoreactivity of 1116 NS $19-9$ monoclonal antibody defined monosialoganglioside (gastrointestinal cancer associated antigen, GICA) has been studied in a series of colorectal carcinoma patients of a multicentre prospective controlled trial in order to assess its correlation with parameters such as localization, stage, histopathological characteristics and DNA flowcytometry. GICA could be detected in $60 \%$ of the carcinomas; but no correlation was observed between its status of immunoreactivity and any of the parameters studied.

It is concluded, that, though study of the expression of the monosialoganglioside may be worthwhile in relation to fundamental aspects of behaviour of colorectal carcinomas, the significance of its immunohistochemical detection in a diagnostic or prognostic sense is limited.

Published in: Int. J. Cancer; $32: 289-293,1983$ 
In 1979 Kopkowski and coworkers were the first to establish a large serles of stable hybridoma clones secreting colorectal carcinoma - reactive monoclonal antibodies IKoprowski et al. 1979). One of these antibodies, produced by the 1116 NS 19-9 clone, appeared to possess promising characteristics, since it did not react with carcinoma cell Iines other than colorectal. Binding of this antibody was intibited by serum from patients with adenocarcinoma of the colon, stomach and pancreas, but not by serum from patients with other forms of intestinal pathology or from healthy individuals (Koprowski et a l, 1981 ). Furthermore, the target-antigen was found in sera and urine of colon carcinoma patients (chang et al, 1981 ).

The target-antigen was characterized as a monosialoganglioside, Which was claimed to be detectable in colorectal tissue and meconium only (Magnani et a 1, 1981). Based on these findings the antigen was considered to be of oncofetal nature and potentially useful for the detection and study of colorectal carcinomas (Steplewski and Koprowski, 1982) and a kit (Centocor Ca 19-9 RIA) for assessment of antigen levels in serum and urine was marketed for use in gastrointestinal cancer.

However, immunoperoxidase studies on the monoclonalantibody defined monosialoganglioside (Gastrointestinal Cancer - associated antigen, GICA) have shown it to be more widely distributed than originally proposed (Atkinson et al, 1982 and the oncofetal nature of the antigen has been challenged (Arends et al, 1983).

To further delineate the characteristics of the monosialoganglioside and to evaluate its usefulness as a marker in colorectal carcinoma we tested its immunoreactivity in histological sections of a large series of carcinomas of the large bowel and compared the results with gross and histological characteristics and with flow-cytometrical data.

The results indicate that the presence of GICA is neither correlated with the localization nor with the stage of the tumour. In addition, there appears to be no statisticly significant correlation with the histological degree of differentiation of colorectal cancers, nor with DNA flow-cytometrical parameters.

\subsection{Materials and methods}

\subsubsection{Tis isues}

Blocks of paraplast embedded colorectal carcinoma tissue were collected from a multicentre prospective controlled trial (carried out from jan. 1979 through jan. 1982), which compares the value of the conventional versus no-touch surgical approach in colorectal cancer. Patients with adjacent organ invasion or distant metastases were excluded from the 
clinical trial, but this category of patients was included in this study, bringing the total number of cases to between 307 and 312 , depending on the parameter studied.

\subsubsection{Classification of specimens}

All pathological specimens were reviewed by two independent observers (J.W. A. and C.T. T.) and classified according to their localization, stage and degree of differentiation.

3.3.3. Localization

Concerning localization, tumours of the cecum and colon ascendens were taken together. whereas tumours of the hepatic and splenic flexure were classified as carcinomas of colon transversum.

\subsection{4. staging}

For staging purposes the Turnbull modification of the original Dukes" classification (Turnbull et al. "1967) was employed:

Stage A Tumour confined to the bowel wall.

Stage $B$ Extension of tumour into pericolic fat.

Stage $C$ Tumour with regional lymphnode metastases.

Stage $D$ Distant organ metastases or infiltrative growth into adjacent organs.

\subsubsection{Grading}

The degree of differentiation was rated according to criteria adopted from Blenkinsopp et al., (1981) modified as follows:

a. well-differentiated : tumours entirely consisting of glandular formations with up to two layers of lining cells with preserved nuclear polarity (fig. 1. A)

b. poorly differentiated : tumours with more than 108 solid growth pattern (fig. 1.B)

c. moderately differentiated : all tumours covering the spectrum between a. and b. (fig. 1.C-D).

Using these criteria the majority of tumours were graded as moderately differentiated. This group was further subdivided into "moderately differentiated" and "moderately differentiated tending to poor" (mod. poor). The latter category consisted of carcinomas with a tendency to form solid areas (up to $10 \%$ ) or a marked cribriform growth pattern. (fig. 1. D). Tumours were classified as undifferentiated when they did not show any glandular structures. Mucinous carcinomas were graded as out ined above. Pure signetring-cell carcinomas were excluded from this study. Grading was based on examination of two or more sections from different parts of the tumour and the least differentiated part observed was selected for grading. 

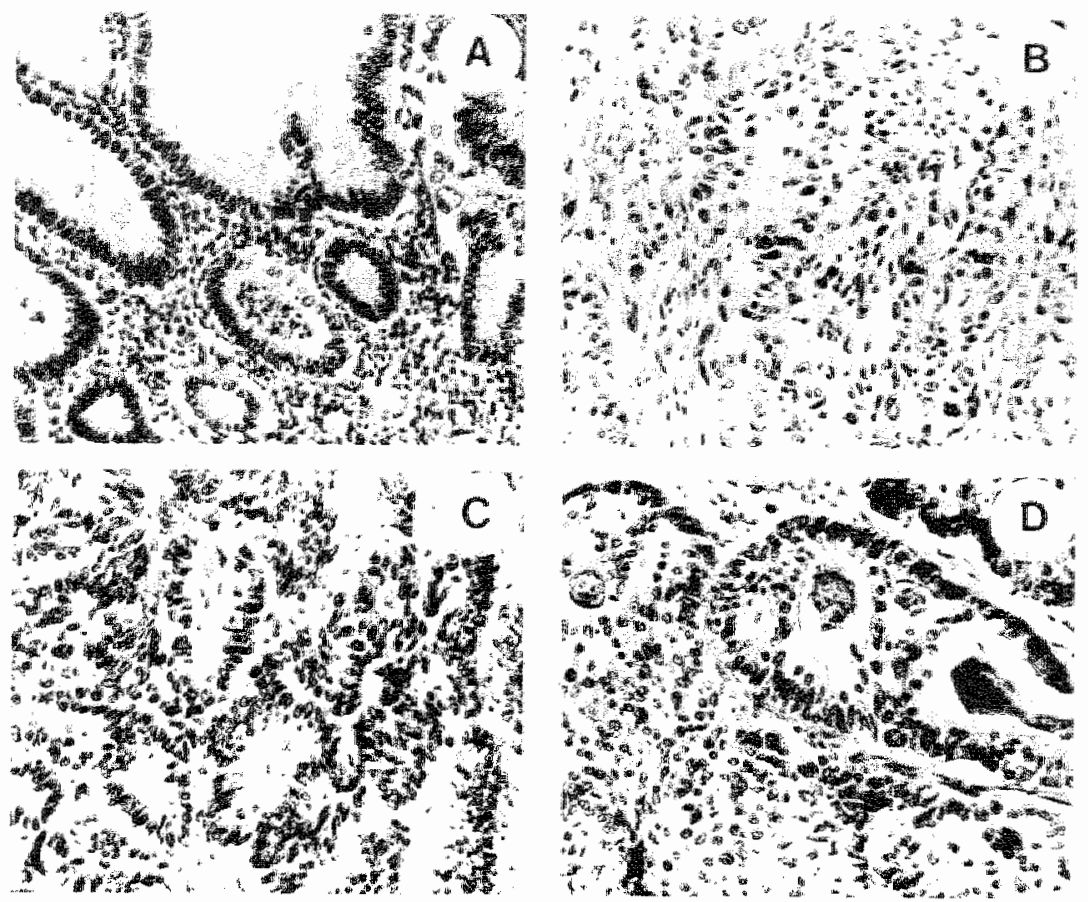

Fig. 1. A. Well-differentiated, the process is entirely made up of glandular structures. B. Poorly-differentiated, the $t$ un o $u r$ forms extensive solid areas. C. Moderately-differentiated, the epithelium of the glandular structures consists of more than two layers and nuclear polarity is not preserved. D. Moderate$1 y$-differentiated with a tendency to poor differentiation (mod. poor), the tumour tends to grow in a cribriform or solid pattern. $H / E \times 150$.

3.3.6. Immunohistochemistry

For immunohistochemical detection of the 1116 NS 19-9 target antigen one block, preferably containing tumour tissue and adjacent normal mucosa, was studied. Details of the staining procedure, which was applied after trypsinization of the sections and using an indirect immunoperoxidase technique, have been published previously (Arends et al, 1983 )

stalning with a non-immune mouse serum served as negative control and a known positive colorectal carcinoma was used as positive reference tissue. 


\subsubsection{Scoring of inmunoreactivity}

Immunoreactivity was scored according to distribution in such a way that a distinction was made between tumours displaying a reaction product in over 80 of the areas of cancerous growth (positivel, tumours reacting scarsely (less than 5 of all areas or not at all (negative) and tumours showing reactivity in 5-80 of the neoplastic tissue, other parts being negative (focally nositive) (fig. 2.A-B).
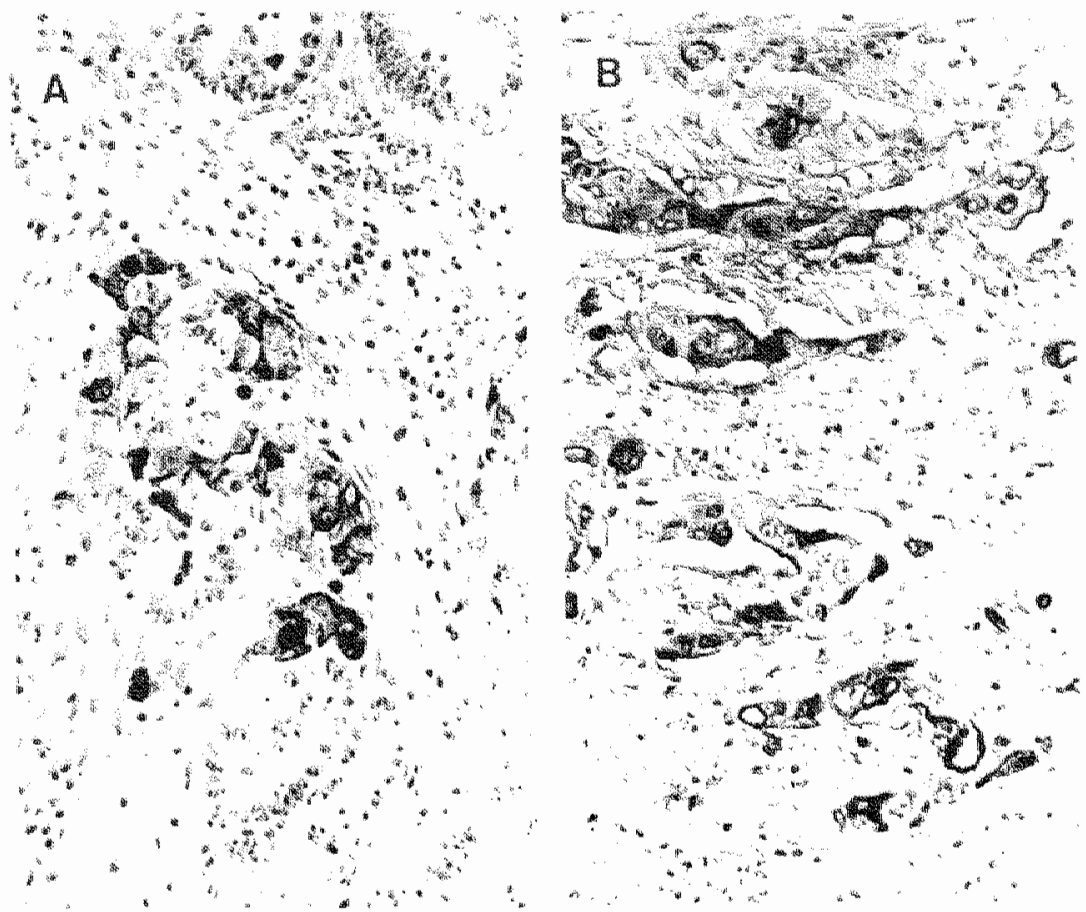

F1g. 2. Mode of GICA expression in coloncarcinoma: A. focal expression pattern. I.P. $x$ 120. B. positive expression pattern. I.P. 150 . 
3.3.8. Plowcytometry

Method flow cytometric analysis was performed on isolated ruclei according to the method of vindelov et al. (Vindelov et al, 1983a; Vindelov et a1, 1983b). Briefly; Eresh tumour tissue was minced with scalpels in a citrate bufter. Aljquots of 100 wl (approximately $2.10^{6}$ cells) were mixed with 900 w of solution A (trypsin 30 wg/ml). After 10 minutes at room temperature 750 ul of solution B lsoybeam trypsin inhibitor $500 \mu g / m l$, ribonuclease $100 \mu \mathrm{g} / \mathrm{ml}$ was added. After another 10 minutes at room temperature 750 y. of ice cold solution $C$ (propidiumiodide $42 \mathrm{ug} / \mathrm{ml}$, sperminetetrahydrochloride $3 \mathrm{~mm}$ ) was added. After each addition the tubes. were inverted to mix the contents gently. Samples were kept on lice and run on a FACS IV (Becton \& Dickinson, Sunnyvale, CA) between 15 minutes and 3 hours after staining. Nuclear DNA content was measured using chicken and trout red blood cells as reference standards and expressed as DNA

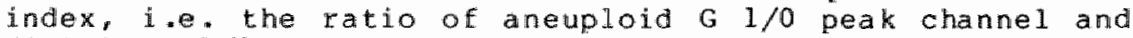
diploid $G 1 / 0$ peak channel. When possible the percentage of cells in $s$ phase was calculated.

\subsection{Results}

3.4.1. GICA immunoreactivity in colorectal carcinoma

of 312 cases of colorectal carcinoma 10,68 showed GICA immunoreactivity, 53.58 showed focal immunoreactivity and 35.9 was negative. In the positive and focally positive cases the reaction product was always localized in the apical cytoplasm and luminal secretion products (fig. 2.A-B). Immunoreactivity of normal adjacent colonic mucosa was studied in 250 cases. 39,6 was positive, invariably focal. In 7,28 the mucosa was positive, whereas the adjacent tumour was negative. 
3.4.2. GICA expression and localization

The pattern of GICA immunoreactivity in relation to the site of the primary tumour is shown in table. I. In mone of the regions the percentage of positive tumours differed $\mathrm{s}^{-}$ nificantly from the overall percentage of immunoreative tumours $(\mathrm{p}=0.2)$.

\section{TABLE I}

\section{GICA - IMMUNOREACTIVITY AND LOCALISATION OF THE TUMOUR}

Ascending colon

$22(32.8)$

foca $11 y$ positive number (perc.) number

(perc.)

positive total number/

(perc.)

Transverse colon

$11(32.4)$

$16(47.1) \quad 7(20.6)$

Descending colon

$43(43.4)$

$48(48.5) \quad 8(8.1)$

99

and sigmoid

Rectum

$3.6(32.4)$

$62(55.9)$

$13(11.7)$

111

Potal

$1.2(36.0)$

$166 \quad(53.4)$

$33(20.6)$

311

$p=0.2$ 
3.4.3. GICA expression and staging

In table II GICA immunoreactivity is shown relative to staging. Again no correlation between the two parameters was found $(p=0.3)$.

\section{TABLE II}

\section{GICA - IMMUNOREACTIVITY AND STAGING}

\begin{tabular}{|c|c|c|c|c|c|c|c|c|}
\hline \multirow[b]{2}{*}{ Stage } & \multirow[b]{2}{*}{$A$} & \multicolumn{2}{|c|}{$\begin{array}{l}\text { negative } \\
\text { number/ } \\
\text { (perc.) }\end{array}$} & \multicolumn{2}{|c|}{$\begin{array}{l}\text { focally } \\
\text { positive } \\
\text { number/ } \\
\text { (perc.) }\end{array}$} & \multicolumn{2}{|c|}{$\begin{array}{l}\text { positive } \\
\text { number/ } \\
\text { (perc.) }\end{array}$} & \multirow[t]{2}{*}{$\begin{array}{l}\text { tota } 1 \\
\text { number }\end{array}$} \\
\hline & & 31 & $(44.3)$ & 35 & $(50.0)$ & 4 & $(5.7)$ & \\
\hline Stage & $\mathrm{B}$ & 41 & $(34.5)$ & 64 & $(53.8)$ & 14 & $(11.8)$ & 119 \\
\hline Stage & $c$ & 33 & $(35.1)$ & 48 & $(51.1)$ & 13 & $(13.8)$ & 94 \\
\hline stage & $\mathrm{D}$ & 7 & $(24.1)$ & 20 & $(69.0)$ & 2 & $(6.9)$ & 29 \\
\hline Tota 1 & & 112 & $(35.9)$ & 167 & $(53.5)$ & 33 & $(10.6)$ & 312 \\
\hline
\end{tabular}


3.4.4. GICA exprssion and grading

In table III GICA immunoreactivity is compared with tumour grade. No relation was found between GICA immunoreactivity and histological degree of differentiation. However; positive tumours did not seem to occur in the poorly differentiated and undifferentiated group and occured slighty more often in the well differentiated and moderately differentiated tumours, whereas negative tumours tended to occur slightly more often in the group of poorly and undifferentiated carcinomas. This trend, however, did not reach statistical significance $(\mathrm{p}=0.5)$.

\section{TAB LE III}

\section{GICA - IMMUNOREACTIVITY AND DIEEERENTIATION GRADE}

negative focally positive totall
positive

\begin{tabular}{|c|c|c|c|c|c|c|c|}
\hline we 11 diff. & 12 & $(38.7)$ & 14 & $(45.2)$ & 5 & $(16.1)$ & 31 \\
\hline Moderately diff. & 47 & $(33.1)$ & 77 & $(54.2)$ & 18 & $(12.7)$ & 142 \\
\hline Mod. poor diff. & 38 & $(36.9)$ & 57 & $(55.3)$ & 8 & $(7.8)$ & 103 \\
\hline Poorly diff. & 13 & $(46.4)$ & 14 & $(50.0)$ & $\mathbb{1}$ & $(3.6)$ & 28 \\
\hline Undiff. & 2 & $(66.7)$ & 1 & $(33.3)$ & 0 & $(0)$ & 3 \\
\hline $\operatorname{Tota} 1$ & 112 & $(36.5)$ & 163 & $(53.1)$ & 32 & $(10.4)$ & 307 \\
\hline
\end{tabular}


3.4.5. Gich expression and flowcytometry

Figure $3 A-D$ shows the cumulative $D I$ frequency and the cumulative S-phase percentage Erequency in relation to GICA immunoreactivity. The graphs for negative and positive or focally positive tumours appear almost identical, indicating that neither the ploidy level nor the percentage of $\mathrm{S}$-phase cells are related to GICA immonoreactivity.

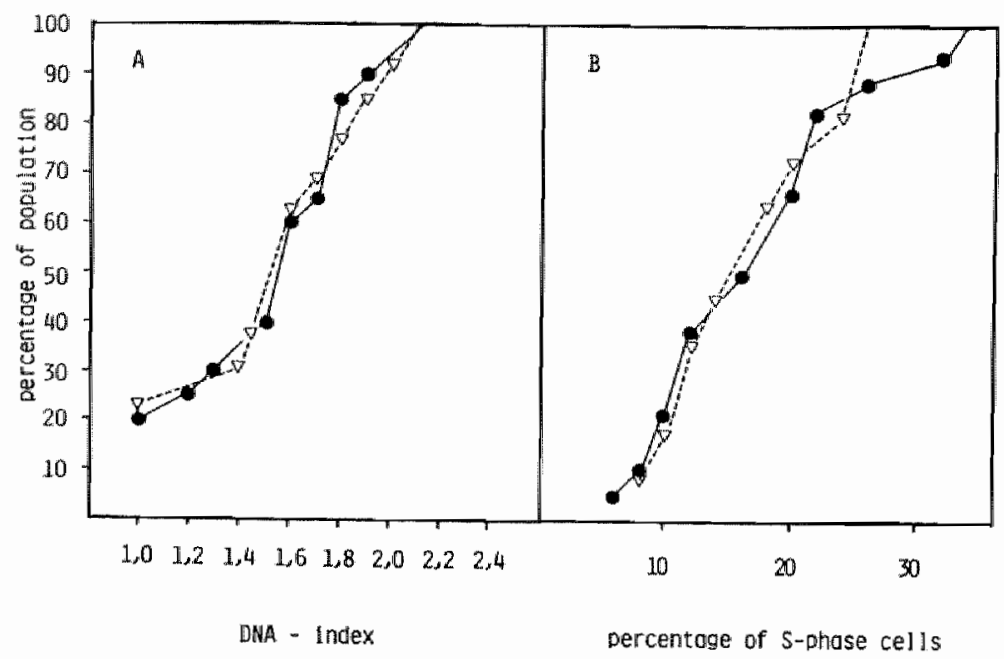

Fig. 3. DNA Index (A) and percentage of $S$-phase cells (B) in relation to GICA expression. A. a cumulative DNA frequency is glven for 13 GICA megative and 20 GICA focally positive colontumours. B. a cumulative S-phase percentage frequency is given for 11 GICA negative and 18 GICA facally positive colontumours. 
Previous studies (Koprowski et al, 1979; Atkinson et 1 , 1982; Arends et al, 1983) demonstrated the presence of the 1116 NS 19-9 monoclonal antibody defined monosialloganglioside in most, but not a 11, colorectal adenocarcinomas and therefore raised the question whether the expression of this antigen was correlated with other parameters in use for tumour staging and classification.

In a large series of colorectal carcinomas we confirmed the absence of the monosialoganglioside in about 408 of the cases, but this phenomenon did not show any statisticly significant correlation with localization, stage, or degree of differentiation of the tumour nor with nuclear DNA content or percentage of cells in the s-phase of the cell cycle. In addition the distribution of GICA defined as completely positive, focally positive or negative, did not correlate with these parameters. Since 7.28 of the negative carcinomas showed a positive adjacent normal mucosa, genetically determined polymorphism as suggested by the finding of a Lewis blood group sugar sequence in the antigen (Falk et al, 1983) can not be the sole factor for absence of immunoreactivity in certain tumours.

Therefore, the phenotypic characteristics correlating with the expression of GICA in colorectal carcinomas remain obscure. Although the possibility that the antigen may be an important characteristic of neoplastic colonic epithelium cannot be entirely excluded, the results of this study indicate that the practical significance of its immunocytochemical detection for histapatholagical use in terms of diagnosis or prognosis is limited, because its expression is not strongly related to factors known to be correlated with prognosis, such as extension and degree of differentiation. DNA content and percentage of $S$-phase cells. (Dukes and Bussey, 1958; Newland et a1., 1981; Chung et al., 1982; Braylan et al., 1980; Barlogie et a 1., 1982 and wolley et al. 1982 ).

Atkinson et al. (1982) observed a loss of immunoreactivity of GICA in bone metastases of colorectal carcinomas. We observed a similar phenomenon in a large series of disseminated colorectal tumours. Whereas lymphnode metastases generally retained the antigen when present in the primary tumour, some of the studied hematogenic organ metastases appeared to have lost the antigen. This phenomenon will. be subject of a next report by our group.

In due course the GICA immunoreactivity status will be correlated with the survival of the patients included in the controlled trial. 
Atends, Jub., Veret1jner, K., Bosman, F.T., Hilgers, J., Steplewski, Z, The distribution of 1116 NS $19-9$ monoclonal antibody defined monosialoganglioside in normat and cancerous human tissues. Mybridoma; 2 : $219-229,1983$

Atklnion, B.P., Errit, C.S., Herlyn, M., Steplewski, Z., Sears, H., Roprowsk1, H. Gastrolntestinal cancer-assoctated antigen in immunoperoxidase assay. Cancer Res.; $42: 4820-4823,1983$

Barlogle, B., Johnston, D.A., Snallwood, L., Raber, M.N., Maddox, A.M., Latrellie, J., Swartzendruber, D.E., Drewinko, B. Prognostic implicathons of ploldy and proliferative actiolty in human solid tumours. Cancer Gen. Cytogen,; 6: 17-28, 1982

Blenkinsopp, W.K. , Steward-Brown, S., Blesovski, L., Kearney, G Flelding, L.P. Histopathology reporting in large bowel cancer. J. Clin. Pathol.; 34: 509-513, 1981

Braylan, R.C., Dlamond, L.W. , Powell, M.L., Harty-Golder, B. Percentage of cells 4 in 5 -phase of the cell cyclle $1 \mathrm{n}$ human 1 ymphoma determined by flow cytometry. Cytametry; 1: 171-174, 1980

Chang, T.H., Steplewsk1, Z., Sears, H.F., Roprowski, H. Detection of monoclonal ant 1 body-def 1 ned colorectal carcinoma antigen by solfd-phase bindting inhibition radLolmmunoassay. Hybrldoma; $1: 37-47,1981$

Chung, G.K., Zatno, R.J., Stryker, J.A. Colorectal carcinoma: evaluation of thlstologic grade and factors influencing prognosis. J. Surg. Oncol.; $21: 143-148,1982$

Dukes, C.E. and Bussey, H.J.R. The spread of rectal cancer and 1 ts effect on prognos1s. Br. J. Cancer; 12:309-320, 1958

Falk, K.E., Karlsson, K.A., Larson, G., Thurin, J., Blaszczyk, M., steplewsk1, Z., Koprowski, H. Mass spectrometry of a humen tumour glycolipld antigen belng defined by mouse monoclonal antibody NS 19-9. Biochem. Blophys. Res. Comm.; 110: 383-391, 1983

Koprowsk1, H., Steplewsk1, Z., Mitche11, K., Herlym, M., Herlyn, D., Fulner, p. Colorectal carcinoma antigens detected by hybridoma antibodles. Som. Cel1 Gen.; 5: 957-972, 1979

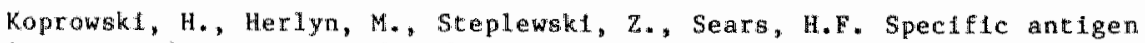
in serum of patients with coloncarclnoma. Sclence; $212 ; 53-55,1981$

Magnand, J.L., Brockhaus, M., Smith, D.F., Gilnsburg, V., Blasziczyk, M., Mitched1, K. F., Steplewsk1, Z., Koprowsk1, M. A monosialoganglioside is * monoclonal antibody-defined antigen of coloncarcinoma. Sclence, 212: $55-56,1981$

Newland, R.C., Chapuls, P.H., Phells, M.T., MacPherson, J.G. The relationship of survival to staging and grading of colorectal carcinoma. 
Cancer: $47: 1424-1429,1981$

Steplewski, 2 . and Koprowski, H. Monoclonal atibody dewelopwent in the study of colorectal carcinoma-assoclaced antigens. Methods Cancer Res. $10: 313,1982$

Turnbull, R.B., Kyle, K., Watson, F.R., Spratt, J. Cancer of the colon: the influence of the no-touch isolation technique on survival rates. Ann. Surg.; 168: $420-427,1967$

Vindelov, L.L., Christensen, I.J. and Nissen, N.I. A detergent-trypsin method for the preparation of nuclei for Flow Cytometric DNA analysis. Cytometry; $3: 323-327,1983^{\mathrm{a}}$

Vindelov, L.L., Christensen, I.J. and NHssen, N.I. Standarization of high-resolution Elow cytometric DNA analy sls by the simultaneous use of chicken and trout red blood cells as internal reference standards. Cytometry; $3: 328-331,1983^{b}$

Wolley, R.C., Schreiber, K., Koss, L.G., Karas, M. and Sherman, A. DNA distribution in human colon carcinomas and tis relationship to clinica behavilour. J. N. C. I.; 69: 15-22, 1982 
GASTROMNTESTLAL CANCER ASSOCTATED ANTIGEN (GICA) IMMUNOREACTIVITY IN COLORECTAL CARCINOMA IN RELATION TO PATIENT SURVIVAL.

J.W. Arends, T. Wiggers, C. Verstijnen, J. Hilgers and $F_{*}$ T. Bosman .

\subsection{Summary}

Immunoreactivity of Gastro-Intestinal Cancer Associated antigen (GICA) was studied in tissue sections of 311 colorectal cancer patients and the results were correlated with data on patient survival. The group of umiformly GICA positive tumours (10.6\%) tended to behave more aggressively than GICA focally positive (53.48) and GICA negative tumours (36.08), also when stratified for stage of tumour extension and histological grade. This trend, however, did not reach statistical significance, which may be the result of a bias introduced by the relatively small number of GICA pasitive cases.

There appeared to be no significant difference in clinical course between patients with GICA focally positive or GICA negative tumours (together comprising $89.4 \%$ of the total population studied).

Further studies including a larger number of patients and longer follow-up periods are needed to validate the suggestion that GICA positive colorectal carcinomas might show a behaviour worse than tumours displaying other modes of GICA expression. However, the results of our study suggest that GICA immunoreactivity in colorectal carcinoma tissue is unlikely to be a sensitive independent parameter for the prediction of prognosis in individual patients.

Submitted to: Int. J. Cancer. 
Gastro-Intestinal cancer Associated antigen (GICA) is a monosialoganglioside (Magnani et al., 1981), which can be detected by a monoclonal antibody produced by the $1116 \mathrm{NS}$ 19-9 hybrid clone (Koprowski et al., 1979). On account of early observations GICA was considered to be of possible oncofetal nature (Roprowski et al. 1981; Magnani et al." 1981) and useful for the detection of gastrointestinal cancers (Steplewski and Koprowski, 1982). More recent studies have cast significant doubt on the oncofetal nature of the antigen (Atkinson et a1., 1982; Arends et a1., 1983a) and also its monosialoganglioside nature (Raux et al. 1983). since the antigen could be detected in serum and urine of patients with colonic caycinoma (chang et al.. 1981) a RIA kit (Centocor Ca $19-9 \mathrm{r}$ ) was marketed for use in gastrointestinal cancer.

Currently, investigations are being carried out evaluating the prognostic value af serial monitoring of GICA serum levels in colorectal cancer patients. At the same time, however, it is conceivable, that the presence or absence of this antigen in colorectal carcinoma tissue may identify subgroups of tumours which show differences in behaviour in terms of patient survival.

In a previous study we have found that GICA immunoreactivity in colorectal carcinoma was not correlated ith parameters known to be of prognostic significance such as localization, stage and histological grade (Arends et al." $1983 \mathrm{~b})$. In the present study GICA tissue immunoreactivity in tissue sections was studied directly in connection with data on patient survival.

\subsection{Material and methods}

4.3.1. Patients and clinical follow-up data

Tissue specimens of 311 patients entered in a multicentre prospective controlled clinical trial (carried out from January 1979 through January 1982) aimed at comparing the value of the conventional versus no-touch surgical approach in colorectal cancer were used in this study. In addition to several clinicopathological data, follow-up data on local recurrence, occurence of metastases and survival were consistently collected according to protocol and computerized. Survival data were corrected for non-disease-related death. Follow-up time varied from 20 to 55 months with a mean duration of 34 months. No patients were lost to followup.

\subsubsection{Staging and grading procedures}

staging and grading were performed according to criteria out 1 ined previously (Arends et all., 1983b). 
4.3.3. Immunocytochemistry

GCA immunoreactivty was studied applying an indirect immunoperoxidase procedure on trypsinized parafin embedded tissue sections. Details of this procedure, using 111645 19-9 monoclonal antibody, bave been published previously (Arends et al. 1983 a). Semiquantitative scoring of immunoreactivity into three categories (negative, focally positive and positivel was performed according to criteria reported before (Arends t al. 1983 b).

\subsection{Statistical analysis}

Life tables were analyzed according to the product-limit method based on individual survival times (Kaplan-Meier) and statistical calculations on the cortelation of SC-immunoreactivity and survival data were done using the logrank lest (Mantel/Cox) and the generalized willcoxon test (Breslow) with the aid of the BMDP (Biomedical Computer Program p series.

\subsection{Results}

4.4.1. Validity of the GICA immunoreactivity score

In order to asses the intratumour variability in GICA imanoreactivity we scored multiple immunostained sections from different parts of the tumour in 20 cases. The results (table I) show that tunours, which are uniformly GICA negative or uniformly GICA positive on one section, show very little regional variation in GICA expression. Only in one case (1.1*), in which the tumour consisted of foci of mucinous (GICA positive) and colloid (GICA negative) differentiation significant variability between sections occurred. In contrast, carcinomas with focal GICA immunoreactivity showed appreciable variation in the relative proportion of GlCA positive cells on different sections. Therefore, focally GICA positive tumours were not further subdivided according to the relative proportion of GICA positive cells.

\subsubsection{General pattern of GICA imunoreactivity}

Table II shows the general pattern of GrCA immunareactivity in the population of 31 patients studied. The group of uniformly GICA positive tumours represents a minority $(10.68)$. The majority of the tumours showed only focal $(53.48)$ or no $(36.08)$ GICA immoreactivity. The distribution of the cases over the various stages of tumour extension and histological grades is compiled in table II . 


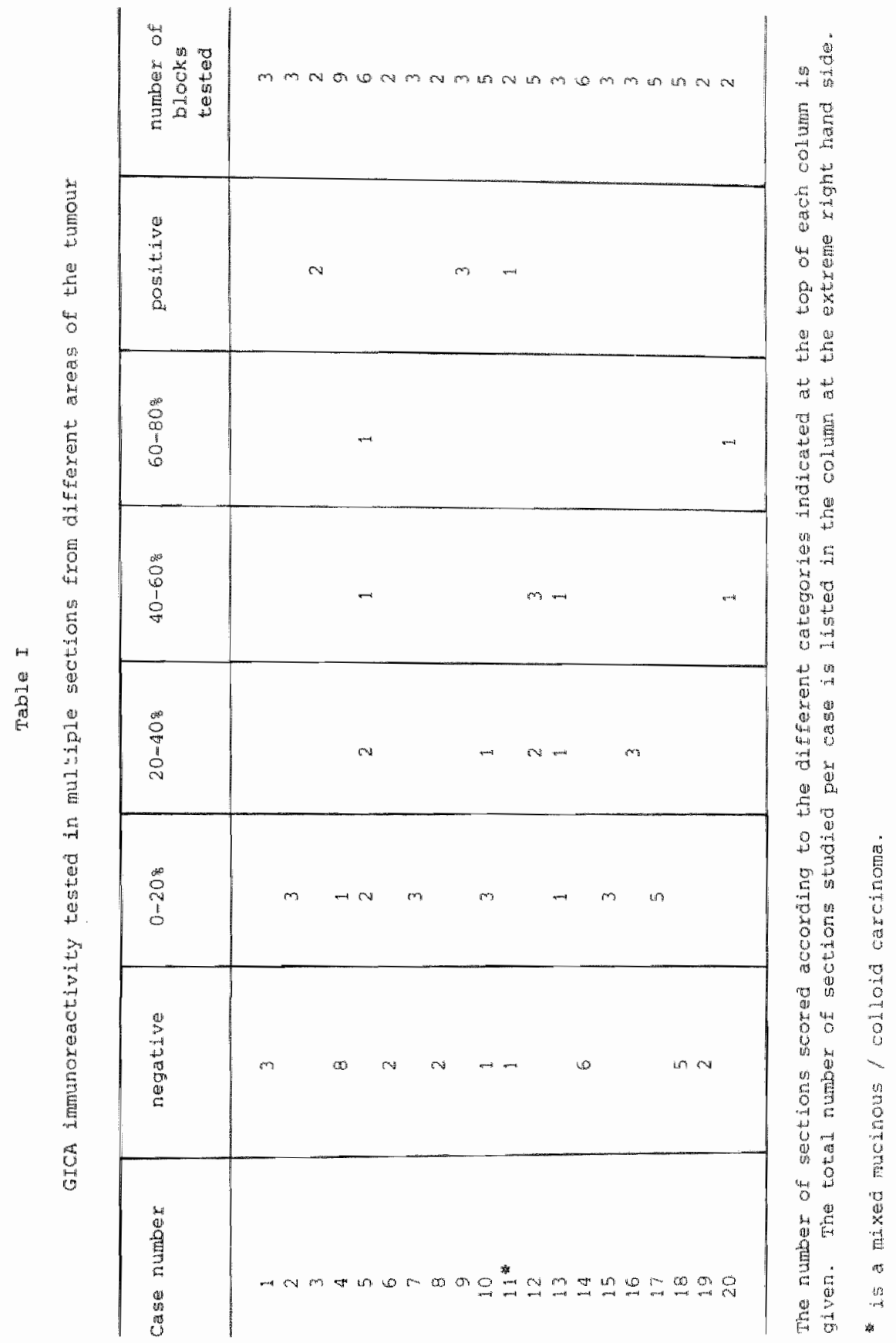


number/percentage

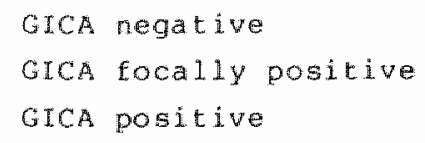
A
B.
C
D

Tota 1

Grade

We 11-differentiated

Mod. - differentiated

Poorly differentiated

und ifferentiated

Tota 1
$112 / 36.0$
$166 / 53.4$
33710.6
$311 . / 100.0$

\section{TABLE III}

STAGE AND GRADE OF 311 COLORECTAL CARCINOMAS 
P-VALUES OF THE CORRELATIONS BETWEEN THE STATUS (POS ITIVE, FOCALLY POS ITIVE AND NEGATIVE)

OF GICA EXPRESSION AND SURVIVAL IN PATIENTS

STRATIEIED FOR THE VARIOUS STAGES AND HISTOLOGICAL GRADES

$a=p($ wilcoxon $)$

a

0.88

0.37

Poorly differentiated

Und ifferentiated
0.19

0.75

0.15

0.26

0.33

0.34

$b=p($ Mantel $/(\operatorname{Cox})$

b

0.74

0.61

0.30

0.45

0.15

0.26

0.07

0.06 
4.4.3. GICA immunoreactivity in relation to patient survival The curve relating GICA immuroreactivity to patient survival is shown in 19 . 1. GICA positive patients tend to have a survival time shorter than patjents with focally GICA positive and GICA negative tumours. However, this trend does not reach statistical significance $(\mathrm{p}$ (Wilcoxon) $=0.33, \mathrm{p}$ (Mante $1 / \operatorname{cox})=0.25)$. There appears to be no difference in survival time between focally GICA positive and GICA negative patients.

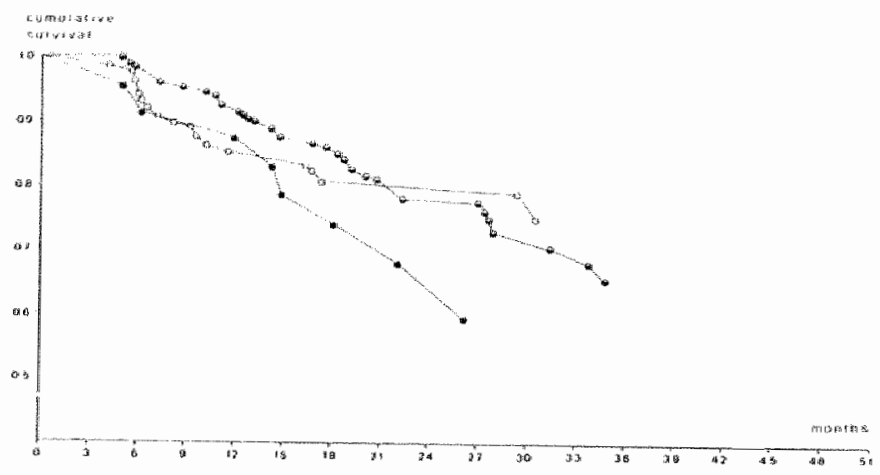

Figure 1: GICA immoreactivity related to cumulative survival in months $\mathrm{p}$ (Milcoxon) $=0.33 \mathrm{p}$ (Mantel/Cox) $=0.25$

O-O GICA negative tumours. O- GICA focally positive tumours. Gica positive tumours.

4.4.4. Stratification for stage and grade

Since the stage of extension of the tumour and the histological grade are parameters with a well established prognostic significance in colorectal cancer patients, we stratified our patient population for these parameters to determine whether a possible prognostic significance of GrCA expression could have been obscured by indiscriminate testing. Ewen after stratification for stage and histological grade, however, GICA expression was not corcelated with patient survival. Figs. 2 and 3 show the curves relating GICA expression to survival of Dukes $B$ patients and patients with moderately differentiated tumours. The p-walues for the corcelations of GICA expression and survival stratified for the various stages of extension and histological grades are listed in table IV. None of these values indicate statistical significance. 


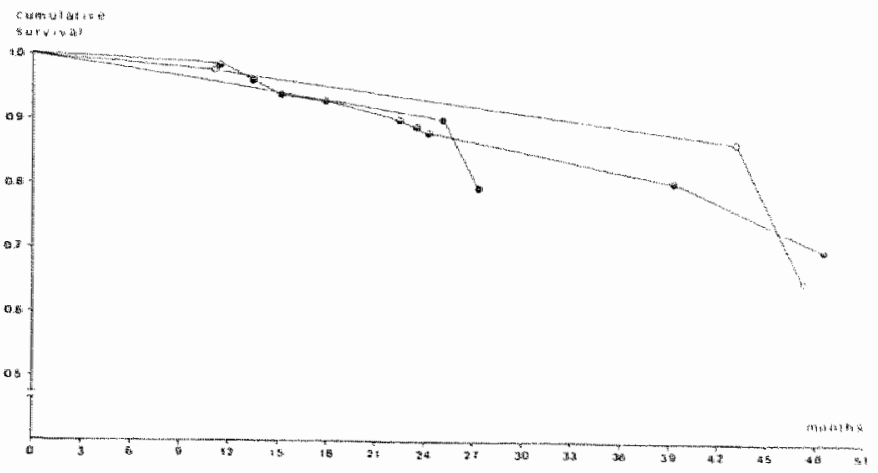

Pigure 2: GICA immunoreactivity of Dukes" B patients in relation to cumulative survival. p (Wilcoxon) $=0.37 \mathrm{p}$ (Mantel/Cox) $=0.61$

- 0 GICA negative tumours. $-\infty$ GICA focally positive tunours. GICA positive tumours.

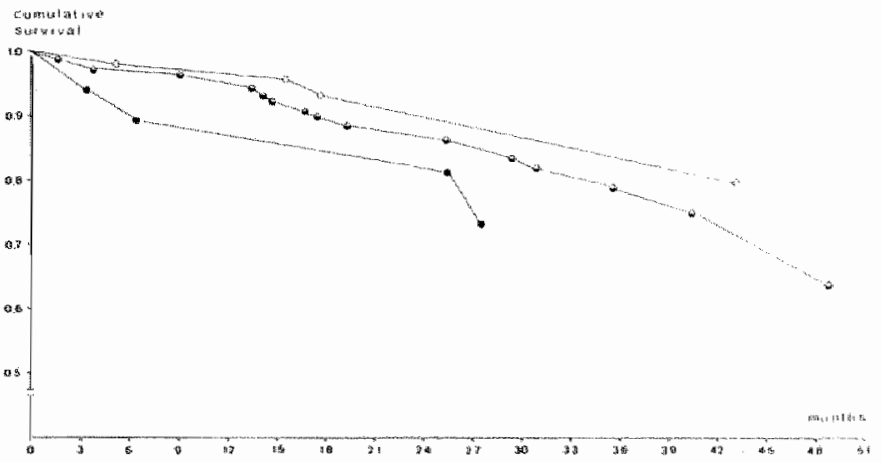

Figure 3: GICA immunoreactivity in patients wth moderately differen tiated colorectal carcinomas $\mathbb{1 n}$ relation to cumlative survival $\mathrm{p}($ Wilcoxon $)=0.26 . \mathrm{p}($ Mantel/Cox $)=0.26$

O- GICA negative tumours. - -0 GICA focally positive tumours. GICA positive tumours. 
According to early reports the occurrence of Gastro-Intestinal Carcer Associated antigen (GICA), the 11 I $6 \mathrm{NS}$ I9-9 monocional antibody-defined monosialoganglioside, seemed to be restricted to gastro-intestinal cancers (koprowsi et a1., 1979) and fetal products (Magnani et a 1., 1981). ThereEore it was met with high expectations as a new antigen of possible oncofetal nature, not related with CEA (Koprowski et al.. 1981). Further studies, however, demonstrated GICA to occur in tumaurs other than of gastro-intestinal derivation and in several normal adult tissues Atkinson et al." 1982, Arends t a . 1983a). Also, since GICA immunoreactivity in colorectal carcinoma tissue did not correlate with sevaral parameters of well established prognostic importance, such as stage (Dukes and Bussey, 1958). histological grace (Chung et al., 1981), DNA content (Barlogie et al.., 1982; Wolley et a1., I982) and percentage of S-phase cells (Bxaylan et a 1., 1980) the diagnostic and prognostic value of tissue GICA immunoreactivity seemed to be linited (Arends et $\left.x_{1}, 1983 \mathrm{~b}\right)$.

The results of the present study indicate that patients with GICA positive turiours tend to have shorter survival periods than patients with tumours displaying ather modes of GICA expression and therefore suggest that the presence of the GICA antigen in colorectal cancer cells might be associated with a more aggressive behaviour. Since more aggressive behaviour of tumour cells is generally associated with loss of antigen expression rather than acquisition of new antigens, GICA would be an antigen of interest in cell biological studies on the mechanisms involved in aberrant cellular behaviour. The lack of statistical significance as well as certain other methodological considerations, however, ask for cautious interpretation of our data.

In regard of these methodological considerations, first$1 y$, it should be realized, that the median follow-up time of 34 months is rather short and may not allow identification of an appreciable difference in survival time. The influence of accepted prognostic parameters, such as stage of turour extension and histological grade, however, usually becomes apparent within 12 months indicating that a mean follow-up duration of approximately 3 years would have to be sufficient to establish the value of GrA expression as a prognostic parameter.

Secondly, it is conceivable that the relatively small number of GICA positive tumours laccounting for only $10.6 \%$ of the total populationl and the celatively small proportion of stage $D$ or undifferentiated carcinomas biased our results.

Finally, it should be taken into account that histological evaluation of a rather linited number of sections of tumour tissue introduces a sampling error, which may also intertere with the correlations observed. For these reasons we feel. that an additional study on a larger series of GICA 
positive tumours has to be conducted befoce final conclusions can be draw regarding the possible relationship between tissue GICA immunoreactivity and prognosis in colorectal cancer.

That the potential prognostic walue of GrCA expression at the tissue level may be relevant for the clinical patholom gist, however, seems unlikely. In the present series there appears to be no difference in clinical behaviour between the groups of focally GICA positive and GICA negative colorectal carcinomas and since these groups together comprise almost 90\% of the total population of patients, the sensitivity of GICA expression as a single prognostic parameter apparently remains limited. Inclusion of GICA in a multivariant analysis on the prognostic significance of multiple antigens expressed in colorectal carcinomas may be rewariling. These studies are in progress.

We conclude that our initial results suggest that the presence of GICA expression in colorectal carcinoma cells is associated with a more aggressive behaviour and that as such the determination of GICA expression may be of interest in cell biological studies concerning abberant cellular behaviour. For clinicopathological purposes the suggestion thit patients with GICA positive tumours might have shorter survival times than patients with GICA focally positive and negative tumours deserves further study. In terms of sensitivity, however, the potential prognostic value of GICA expression as an independent parameter in colorectal carcinoma tissue is 1 imited. 


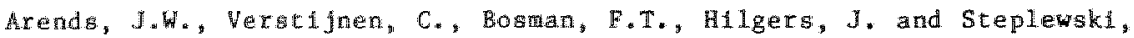
z. Distribution of monoclonal antibody defined nonosialogangliaside in normal and canceroug human tissues: an immoperoxldase study. Hybrido醒; $2: 219-229,1983^{a}$

Arends, J.W., Higgers, T., Schutce, B., Thijs, C.T., Verstijnen, C., Hilgers, J*, Bligham, G.H. and Bosman F.T. Monoclonal antibody (1116 NS 19-9) deflned monostaloganglioside (GICA) in colarectal carcinoma in relation to stage, h1gtopathology and DNA flow cytometry. Int. J. Cancer; $32: 289-293,1983^{6}$

Atkinson, B.F., Ernst, S.C., Herlyn, M., Steplewski, Z., Sears, H.F., and Koprowsk1, H. Gastrolntest lnal cancer-associated antigen in immunoperoxidase assay. Cancer Res.; 42: 4820-4823, 1982

Barlogie, B., Johnston, D.A., Smallwood, L., Raber, M.N., Maddox, A.M., Latreflle, J., Swartzendruber, D.E. and Drewinko, B. Prognostic lmplications of plofdy and prollferative activity in hum solld tumors. Cancer Gen. Cytogen.; 6: 17-28, 1.982

Braylan, R.C., Dlamond, L.W., Powell, M.L. and Hartygolder, B. Percentage of cells in s-phase of the cell cycle in human lymphoma determined by flow cytometry. Cytometry; 1: 171-174, 1980

Chang, T.H. "Steplewskt, Z., Sears, H.F. and Koprowski, H. Detection of monoclonal antibody-defined colorectal carcinoma antigen by solid-phase binding inhibition radiolmmunoassay. Hybridoma; 1: 37-47, 1981

Chung, C.K., Zalno, R.J. and Stryker, J.A. Colorectal carclnoma: evaluation of histologic grade and factors influencing prognosis. J. Surg. Oncol.; $21: 143-148,1982$

Dukes, C.E. and Bussey, H.J.R. The spread of rectal cancer and its effect on prognosis. Br. J. Cancer; 12: 309-320, 1958

Koprowski, H., Steplewski, Z., Mitchell, K., Herlyn, M., Herlyn, D., and Fuhrer, P. Colorectal carcinoma antigens detected by hybridoma antibodies. Som. Cell Gen.; 5: 957-972, 1979

Koprowskl, H., Herlyn, M., Steplewskl, Z., and Sears, H.F. Specific antigen th serun of patients with colon carcimoma. Science; $212: 53-55$, 1981

Magnanl, J.L., Brockhaus, M., Smith, D.E., Ginsburg, V., Blasczyk, M., Mitche11, K.F., Steplewsk1, \%., and Koprowsk1, H. A monoslaloganglioside 18 a monoclonal antibody-defined antigen of coloncarcinoma. Science; $212: 55-56,1981$

Newland, R.C., Chapuls, P.H., Phefls, M.T. and MacPherson, J.G. The relationship of survival to staging and grading of colorectal carcinoma. Cancer; $47: 1424-1429,1981$ 
Raux, H., Labbe, F., Fondareche, M. C* Koprovsk, H. and Burtin, P. A study of gastrolntestinal cancerassociated antigen (GLA) in human fetal. organs; Int. J. Cancer: $32: 315-319,1983$

Steplewski, Z., and Roprowskl, H. Monoclonal antibody development $\mathbb{A n}^{\mathrm{n}}$ the study of colorectal carcinoma associated antigens. Meth. Cancer Res.; Academic Press Inc., London and New York, 1982

Wolley, R.C., Schreiber, R., Koss, L.G., Karas, M. and Sherman, A. DNA distributron in human colon carcinomas and tos relationship to clinical behaviour. J. N. C. I.; $69: 15-22,1982$ 
THE VALUE OF SECRETORY COMPONENT (SC) IMMUNOREACTTVITY IN DIAGUOSIS AND FROGOSIS OE COLORECTAL CARCINOMAS.

J.W. Arends, T. Wiggers, C.T. Thijs, C. Verstijnen, G.J.V. Swaen and F.T. Boman.

5.1. Summary

Immunoreactivity of secretory component (SC) was tested in routinely processed tissue specimens of 314 colorectal cancer patients and correlated with clinicopathological parameters, such as stage and histological grade of the tumours as well as survival data of patients.

In 22 of the carcinomas almost all tumour cells were SC positive, 36 of the tumours showed $S C$ immunoreactivity in a focal, heterogeneous pattern, whereas in $42 \%$ of the carcinomas SC immunoreactivity did not occur. Uniformly SC positive carcinomas demonstrated a tendency to occur more frequently in the low stage and grade carcinomas, whereas uniformly SC negative neoplasms showed the reverse trend. These trends were only statistically significant for stage. Focal, heterogeneous, SC immunoreactivity was not correlated with stage nor with grade. Furthermore, inclusion of SC heterogeneous tumours in the analysis of survival data obscured the statistical significance observed in the correlation of SC immunoreactivity status and patient survival in uniformly SC positive or negative tumours.

It is concluded that the prognostic value of SC immunoreactivity patterns in colorectal carcimoma tissue appears to be limited due to the occurrence of a substantial proportion of tumours with heterogeneous SC expression and is of less signilicance than staging. Nevertheless, determination of the SC immunoceactivity status may be of additional value for the identification of a subpopulation of patients wh a more favourable prognosits.

To be published in: Am. J. Clin. Patholl. (September, 1984) 
Secretory Component (sc), a glycoprotein of $60-70 \mathrm{kD}$ is a product of most glandular epithelia (Tourvilie et al. 1969; Brandtzaeg, 1974; Harris and South, 1981); including the columar cell population of the intestinal epithelium 10'Daly et al., 1971; Brown et al.; 1976).

In the literature repeatedy reports have been published indicating a correlation between the presence of SC synthesis in cells in colorectal carcinoma and their histological grade (Poger et a 1." 1976; Weisz-Carrington et al." 1976 ; Rognum et al., 1980; Rognum et al., 1982; Isacson, 1982) and stage (Rognum et al., 1980, 1982). The histological grade and stage of extension hawe been well established as major prognostic factors in collorectal carcinoma.

In view of the correlation of SC expression with these factors, it is conceivable that determination of SC expression in these tumours might help to predict the clinical course in individual patients. However, as yet no studies have been reported directly relating sc immunoreactivity in colorectal carcinomas to their biological behaviour, expressed in terms of patient survival.

We therefore studied SC immunoreactivity in tissue sections of a large series of collorectal carcinomas in relation to clinicopathological parameters, such as stage and histological grade of the tumours as well as clinical follow-up data of the patients.

\subsection{Material and methods}

The material used for the present study was derived from a multicentre prospective controlled clinical trial comprising 238 patients. This study was initiated to compare the no touch approach of colorectal carcinomas with the conventional surgical approach in terms of patient survival time and disease free interval and was conducted between january 1979 and january 1982. Sex, age, first symptoms, duration of symptoms, preoperative CEA levels, localization, stage of extension and histological grade, as well as follow-up data on local recurrence and metastases were consistently collected according to protocol and computerized.

In addition in the same perlod 76 patients, which could not be entered in the no-touch versus conventional surgical approach trial because of their age, the stage of exterision of the tumour or the technical inability to carry aut a proper no-touch procedure, were included in this study. Clinicopathological data of these patients were collected and computerized in the same way as for the trial patients. A1 pathological reports, histological slides and parafín blocks were assembled in one institution (Mastricht) and reviewed with regard to stage and histological grade by two observers (J.W.A. and C.T.T.) in independent sessions. The cases in which a discrepancy occurred in the judgement of 
the two observers, were reviewed jolntly and a final judgement was made in mutual agreement.

\section{$5.3 .1 .5 \operatorname{taging}$}

A - cumour confined to the bowel wall

D - extersion of tumour into pericolic fat

C - tumour ith regional lymphnode metastases

b - tumour with distant metastases or growth into adjacent structures.

\subsubsection{Grading}

The histological grade of the tumours was estimated on the ledst differentiated areas observed in a minimum of two sections from different parts of the tumour. The applied criteria were adapted from Blenkinsopp et a 1 . (1981) with the following modifications: a. well differentiated: tumours entirely consisting of glandular formations ith up to two layers of lining cells with preserved nuclear polarity (Eig. 1,a). b. poorly differentiated: tumours with more than 10 of a solid growth pattern (fig. $1, b)$. c. moderately differentiated: tumours covering the spectrum between 2 and $b$. With the suboivision "moderately differentiated tending to poor" (mod. poor) i.e. carcinomas with a tendency to display solid areas (up to $10 \%$ ) or a marked cribriform growth patterri (fig. $1, c, d)$.
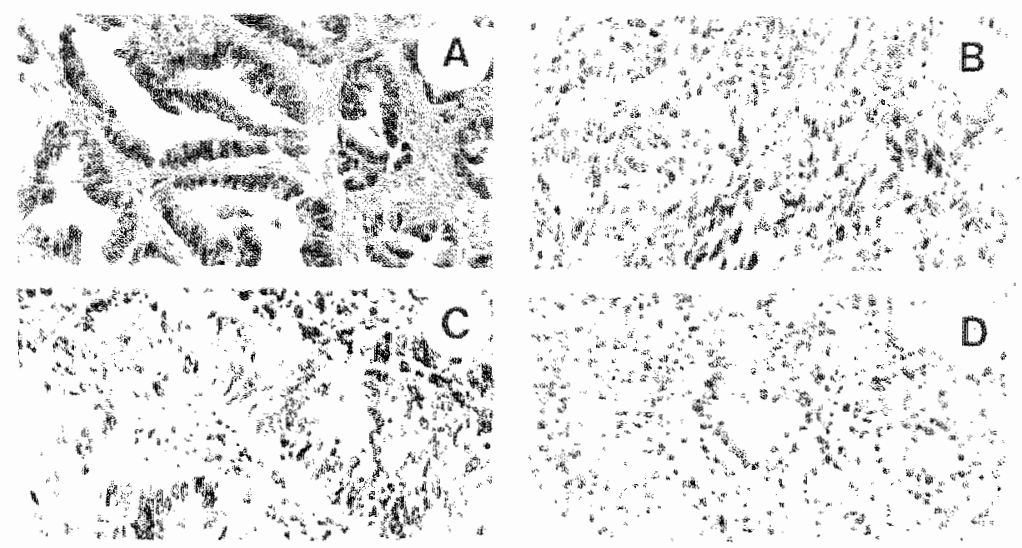

Iig. $1, d, b, c, d$.

a. Well-differentiated adenocarcinoma of colon. The tumour is made up entirely of glands with one ox two layers of 1 inlng cells. H/E $x 150$. b. Poorly-differentiated adenocarcinoma of colon. The tumour largely conslsts of areas with a solld growth pattern. H/E $x 150$. c. Moderately differentigted adenocarcinoma of colon. The tumour shows glandular forntions lined by two or more layers of atypical epithellum. $H / \mathbb{E} x$ 150. d. The tumour displays a marked cribriform growth pattern. H/E $x$ 150. 
5.3.3. Follow-up data

Survival data were corrected for non-disease-related death. Follow-up time varied from 20 to 55 months with a mean duration of 34 months. No patients were lost to follow up.

\subsubsection{Inmunocytochemistry}

One block of formalin fixed parafin embedded tumour tissue, obtained from either the resection or a biopsy specimen at the time of diagnosis and preferably containing adjacent mucosa, was selected and 4 micron sections were cut. Imrunocytochemical staining was performed centrally (Mastricht) in multipie staining sessions spread over 2 months, but using one single batch of antisera. Details of the staining procedure have been published (Arends et al. 1983). Briefly, the unlabeled peroxidase-antiperoxidase method was employed after prior trypsinization of the sections. The antisera used were all obtained from Dakopats (Copenhagen, Denmark) and applied for half an hour at room temperature in the following order and dilutions: rabbit anti SC $1 / 1200$, swine-antirabbit $\mathrm{Ig} 1 / 1000$, rabbit peroxidase-antiperoxidase immume complexes 1/500. Between each incubation the sections were rinsed three times 5 minutes in Tris buffered saline $(\mathrm{pH} 7.6)$. Immunoreactive sites were visualized using diaminobenzidine.

Specificity of the anti-SC antiserum (lot nr. 031 A) was tested by sodium dodecyl sulfate-polyacrylamide gel electrophoresis of the purified antigen followed by immunoblotting. One band was obtained at $70 \mathrm{kD}$. Sections incubated with non-immune rabbit serum instead of anti sc immune serum. served as negative control. Adjacent colonic mucosa served as an internal positive control reference. 
5.3.5. Scoring of intunoreactivity

Scoring of immunoreactivity was performed using the following definitions:

- tumours displaying immunoreactiwity in ower 80 of a 11 tumour cells - positive (fig. 2 , a).

- tumours demonstrating immunoreactivity in 5-80z of the tumour cells - Eocally positive (fig. 2, b).

- tumours reactive in less than 5 of the tumour cells negative (fig. 2 , c).

In positive and focally positive tumours no distinction was made in the mode of $\mathrm{SC}$ expression (i.e. staining of the apical plasma membrane or diffusely cytoplasmic).

Histological grading and scoring of immunoreactivity of the tumour were done in independent sessions.
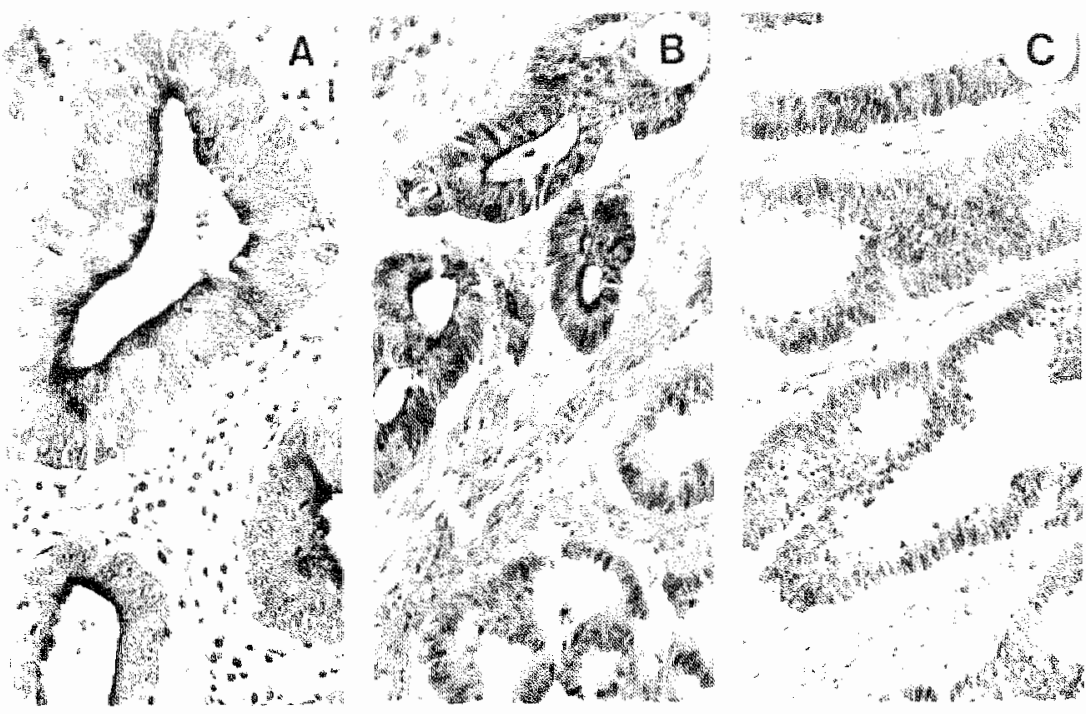

F.t. $2, a, b, c$

a. SC-positive colondc adenocarcinoma with expression of the antigen at the luminar plasmamerubrane and diffusely over the cytoplasm of the epithe lium. Immunoperoxidase $x$ 200. b. SC-focally positive colonic adenocarcinoma. The glandular formations in the upper part of the picture express $\$ C$ where as the antigen is absent in the apical membrane and cytoplasm of the neoplastic elements at the botton. Immunoperoxidase $x 150$. c. Sconegative colonic adenocarcinoma without detectable immonoreactvity for the antigen. Immunoperoxidase $x 150$. 
5.3.6. Statistical analysis

Differences observed in the cross tabulations between $S C$ immunoreactivity and stage as well as grade were tested on their significance with a raw chi-square test for association and p-values were calculated with the aid of SPSS (Sta tistical Package for Social Sciences).

The life tables were analysed according to the product Iimit method based on individual survival times (Kaplan-Meier). calculation of the p-values for statistical evaluation of the differences in regard of the pattern of SC-immunoreactivity was performed with the logrank test (Mantel-cox) and the generalized wilcoxon test (Breslow) using the BMDP (Biomedical Computer Program p-series).

\subsection{Results}

5.4.1. Validity of staging and grading procedures

In order to establish to what extent our staging and especially our grading definitions enabled us to distinguish groups of patients differing in progmasis we first correlated these parameters with the clinical follow-up data. In figures 3 and 4 the curves relating stage and grade of tumours to survival of patients are shown. These Eigures show that patients with stage $C$ and stage $D$ tumours, together comprising 39 of the total population demonstrate significantly shorter survival than patients with stage A and $B$ tumours (p (Wilcoxon) 0.0001, p (Mantel/Cox) 0.0001). Also, poorly differentiated and undifferentiated tumours, together accounting for $10 \%$ of the total population, are associated with shorter survival times in comparison with wel1- and moderately differentiated tumours (p (Wilcoxon) 0.0001 , p (Mante1/Cox) 0.0001$)$. 


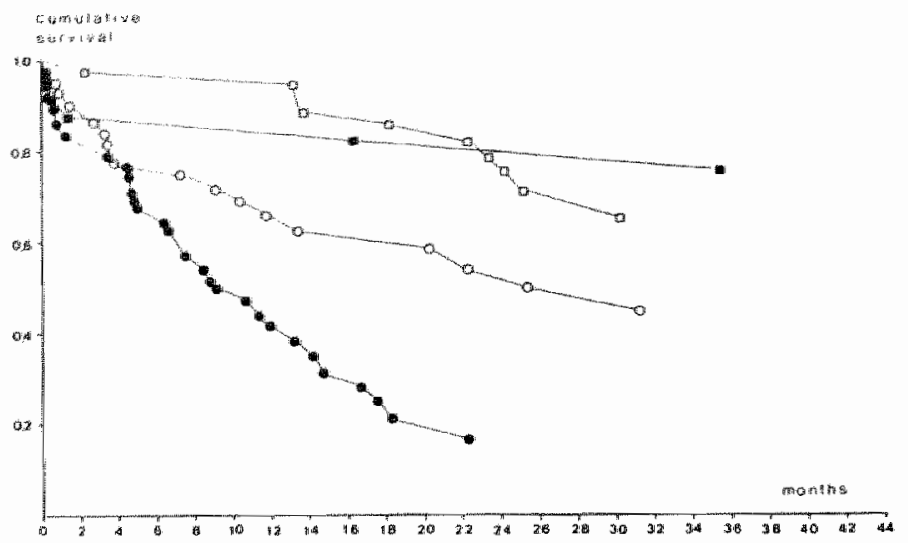

1. 3

Cumulative survival. in relation to stage of tumour extension.
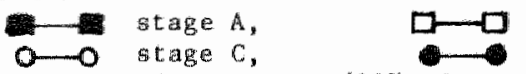
stage $B$, stage D.

Stage $C$ and $D$ tumours ( $39 \%$ of the population) are seen to have survival times different from the rest of the tumours ( $p$ (Wilcoxon) 0.0001 , $p$ (Mante1/Cox) 0.0001 ).

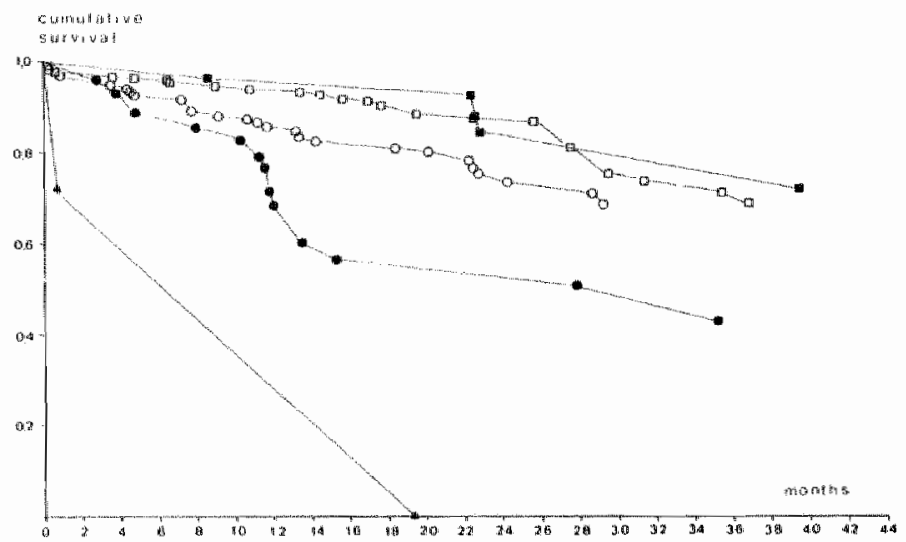

Fis. 4

Cumulative survival in relation to histological grade:

well differentiated. moderately differentiated, O-O moderately differentiated tending to poor, pourly differentiated, und f f f u rentiated.

Undfferentiated and poorly differentiated carcinomas show a cifnical course distlact from the rest of the tumours (p (Wlcoxon) $0.0001, p$ (Mante L/Cox) 0.0001$)$. 
5.4.2. General distribution of SC immunoreactivity Table I shows the general distribution of sc immuroreacm tivity in the 314 cases included in this study. The tumours demonstrated either a uniformly positive (22\%) ox a focally positive (36) staining pattern, whereas 42 showed uniform absence of $\mathrm{SC}$.

TABLE I

SC-IMMUNOREACTIVITY IN 314 COLORECTAL CARCINOMAS

number

percentage

Negative

132

42

Focally positive

113

36

Positive

69

22

5.4.3. SC immunoreactivity and stage/grade

In tables II and III the data on $\mathrm{SC}$ expression in relation to stage and histological grade are compiled.

$\mathrm{SC}$ negative tumours accurred more often in stages $C$ and $D$ $(50-55)$ and in the higher histological grades $(47-64)$ than in the group as a whole (428). Conversely. SC positive tumours occurced more frequently in stages $A$ and $B(32-25$ s and in histologically low-graded tumours (29-288) compared to the whole group $(22 \%)$. These Eindings reached statistical significance in respect of stage ( $p=0.017$ ), but not for grade $(p=0.09)$.

Focal $S C$ immunoreactivity was not correlated with the stage nor with the grade ot colorectal carcinomas. 

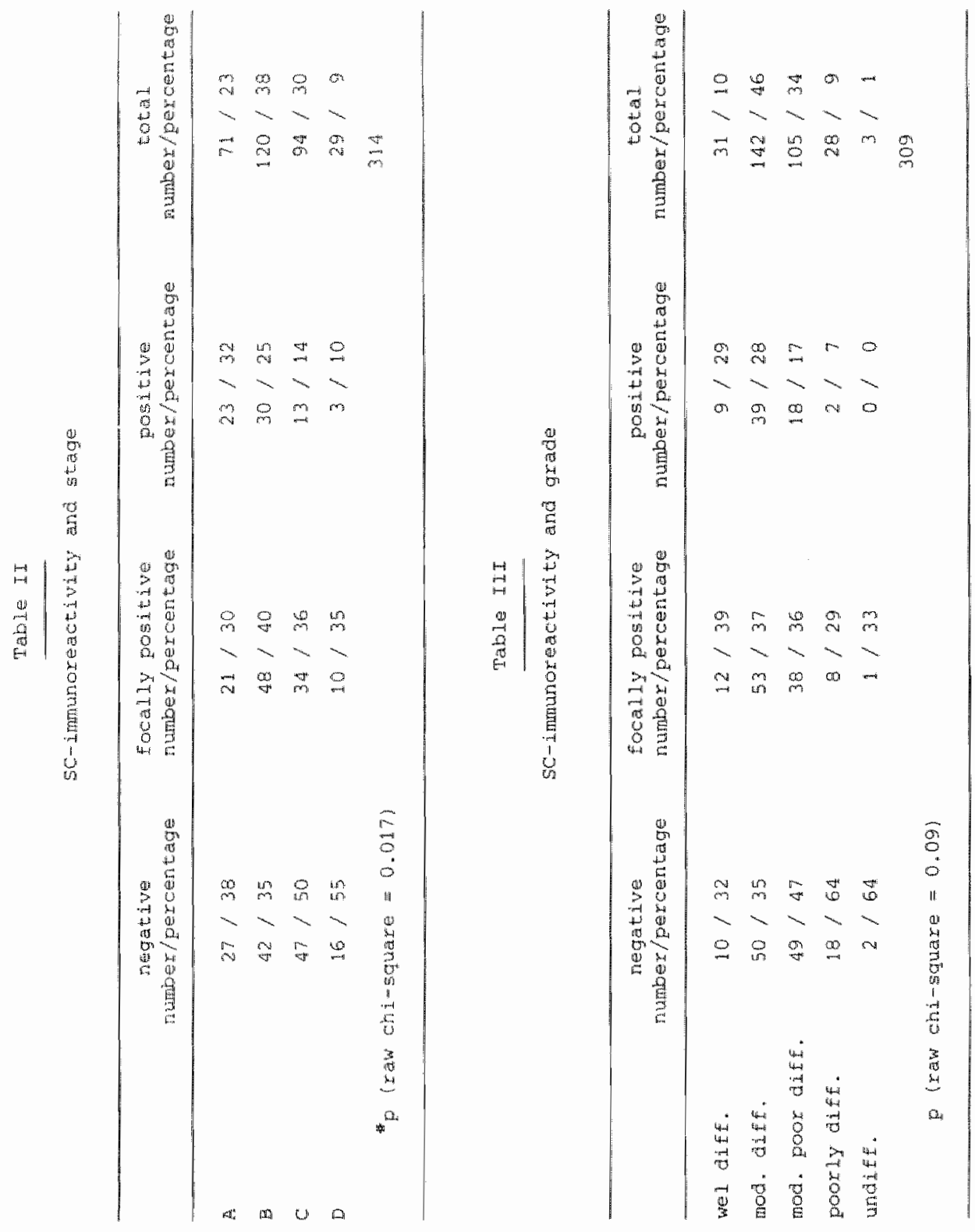
5.4.4. SC immunoreactivity and patient survival

The group of patients with uniformly $\mathrm{SC}$ positive tumours demonstrated a significantly better survival than the groups of patients with focally SC positive and SC negative tumours taken together ( $\mathrm{p}$ (wilcoxon) 0.02 , $\mathrm{p}(\mathrm{Mantel} / \mathrm{Cax}) 0.02)$. A $1-$ so, when SC positive tumours were compared ith SC negative tumours alone a significant difference in survival was found in favour of patients with SC positive tumours (p wilcoxon) 0.017), p (Mantel/ Cox) 0.022 ) (fig. 5).

However, comparison of the group of uniformly SC positive and focally SC positive tumours with uniformly SC negative tumours did not reveal a significant difference in patient Survival ( $\mathrm{p}$ (Wilcoxon) $0.16, p$ (Mantel/Cox) 0.21). No signiEicant difference between uniformly $\mathrm{sC}$ negative and focally SC positive tumours could be noticed (p (Wilcoxon) 0.80), p (Mante1/Cox) 0.89 ).

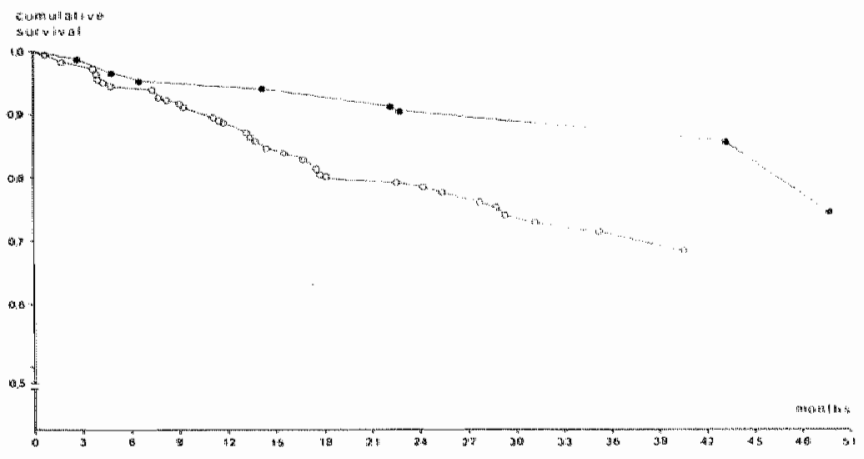

Fig. 5

Cumulative survival in relation to SC immunoreactivity state SC positive, $O-O$ SC negative $p($ Wilcoxon) $=0.017, \mathrm{P}$ (Mantel/(Cox) 0.022 . SC focally positive carcinomas are excluded th this analysis. 
Previous immunocytochemical studies on the expression of $\mathrm{SC}$ in colorectal carcinomas have shown that well-differentiated carcinomas tend to contain more sC positive cells than poorly-differentiated variants. Also a tendency for SC positive tumourg to occur more frequently in the early Dukes' stages has been noticed. Since the extension of the tunour (Dukes and Bussey, 1958; Newland et a 1. 1981) and -to a lesser extent - histological grade (Newland et a 1 , 1981; Chung et al., 1982) are known to be important factors for prognosis in colorectal carcinoma, the results of the studies reported so far in the literature warrant the supposition that determination of the status of SC expression may be of additional value for prediction of the clinical course in individual patients.

The ain of the present study was to reconfirm the correlation of $\mathrm{SC}$ expression with stage and histological grade on a large series of colorectal carcinoma patiens. In addition we intended to correlate tissue $\mathrm{SC}$ immunoreactivity with clinical follow-up data of the patients.

The results of this study largely confirm and extend earlier findings. SC uniformly positive carcinomas demonstrated a tendency to occur more Erequently in the $A$ and $B$ stage and low graded carcinomas, whereas uniformly SC negative neoplasms showed the reverse trend, which however onIy appeared to reach statistical significance in respect of tumour stage. In contrast, focally SC positive carcinomas did not show any correlation with stage nor with grade.

Patients with uniformly SC positive tumours demonstrated significantly longer survival than patients with SC negative tumours. Inclusion of focally SC positive tumours in the analysis of survival data, however, obscured this statistical significance.

In terms of specificity stage of extension and histological grade are better prognostic indicators than SC immunostaining: the differences in prognosis between stage A and D tumours or between well differentiated and poorly differenthated tumours is much more marked (p 0.0001$)$ than that between uniformly SC positive and SC negative tumours (p $0.017)$. In terms of sensitivity $\mathrm{SC}$ immunostaining as prognostic indicator appears to take an intermediate position between stage of extension and grade: staging identified 39 of the patient population as prognostically different, SC immunostaining identitied 22 and grading only $10 \%$. We feel therefore, that the SC immunoreactivity status is a better prognostic variable than the histological grade, but also that Its prognostic value is inferior to that of the stage of extension of the tumour.

In comparing our findings with those reported by Poger et a1.(1976), Rognum et a1. (1980, 1982) and Isaacson (1982) on the same subject, it should be realized, that there are certain difeerences in the applied techniques. Firstly, it 
should be taken into account that we used an immunoperoxidase procedure on formalin fixed and routinely processed tissue to detect SC immunoreactivity, whereas Poger et al. and Rognum et al. applied an immunofluorescence procedure on mildly acetone fixed frozen material. However, we do not believe that this difference in technique is of major importance, since the pattern of SC immunoreactivity we observed is identical to that reported by these authors. Furthermore, the findings of Isaacson who used a procedure similar to ours, are not in contradiction with those of other workers. Another aspect, in which our study differs from others, is the system of scoring of immunoreactivity. Whereas Rognum et al. and Isaacson scored not only the cell numbers but also the intensity of the immunoreaction as a measure of $\mathrm{SC}$ expression, we felt that on our material a similar approach was injustifiable since routine fixation and embedaing procedures may variably affect the immonoreactivity of tissue bound SC, especially in surveys including tissue specimens pracessed in different centers and sections immunostained in multiple staining sessions. We therefore restricted ourselves to scoring of the number of immunoreactive cells as a measure of $S C$ expression in a tumour.

An important aspect to be considered in the search Eor prognostic indicators at the histological level is the phenomenon of phenotypic heterageneity of tumout cells, which in colorectal carcinomas is known to occur in respect of antigen expression (Prehn, 1970; Maclean et al. "1982; Arends et al.. 1984) and histological grade (qualheim and Ga11, 1953). For practical purposes a simple overall classification of SC expression and histological grade is usually performed. Such an overall approach, however, obscures potentially relevant differences between individual tumour celis. Overall classification of a well differentiated tumowr as prognostically unfavourable in relation with absence of $\mathrm{SC}$ immunoreactivity exemplifies this problem. SC producing columnar cells represent only one of the functionally differentiated cell types in colonic mucosa. Other differentiated cells include goblet cells and enteroendocrine cells. It may be hypothesized that only part of the well. differentiated tumours are composed of columnar cell-1ike SC producing cells and that there are other well differentiated tumours with a relatively benign behaviour which are predow minantly composed of goblet-like cells (e.9. mucinous. signet $r i n g$ cell and colloid carcinomas) or enteroendocrine cells (e.g. carcinolds and neuroendocrine carcinomas)."

In summary, our data demonstrate that patients with uniformly SC positive tumours (representing about one Eifth of the total patient population) show a better survival than patients with focally SC positive or SC negative tumours. Therefore determination of the $\mathrm{SC}$ immunoreactivity status in colorectal tumours may be of value for the identification of a subpopulation of patients with a more favourable prognosis. 
Arends, J.H., Gromlowski, H.M, De koning Gans, H.J., Boginan, F.T.: An Imanohistochentcal study of the distribution of secretory component and IgA in the normal and dlseased uterine mucosa. Int. J. Gyn. Pathol.: 2: $171-1.81,19.83$

Arends, J.W., Whgers, T., Verstinen, C. et al.: Tumour cell heterogenelty in primary and metastatic colorectal carcinoma. Prot. Biol. FLuids; $31: 587-594, \mathbb{1 9 8 4}$

Blenkingopp, W.K., Steward-Brown, S., Blesovski, L., Kearney, G., Fielding, $\mathbb{L}$. P. Histopathology reporting in large bowel cancer. I. Clin. Pathol: $34: 509-513,1981$

Brandczaeg, P. Mucosal and glandular distribution of lminoglobulin components: Differential locallzation of free and bound SC in secretory eptethellal cel1s. J. Immuno 1.; 112: 1553-1559, 1974

Grokn, W.R. Isobe, Y., Nakane, P.K. Studies on locallzation of Immonoglobulins across intestinal eplthelium II. Immoelectronmicroscopic localization of immunoglobulins and secretory component in human intestinal mucosa. Gast roenterology; $71: 985-995,1976$

Chung, C.K., Zalno, R.J., Stryker, J.A. Colorectal carcinoma: evaluation of histologic grade and factors influencing prognosis. J. Surg. Oncol." $21: 143-148,1982$

Dukes, C.E., Bussey, H.J.R. The spread of rectal cancer and 1 ts effect on prognosis. Br. J. Cancer: 12: 309-320, 1958

Harris, J.P., South, M. A. Secretory Component. A glandular epithellal cell marker. Ar. J. Pathol.; 105: 47-53, 1981

Isaacson, P. Immunoperoxidase study of the secretory immonoglobulin system in colonic neoplasia. J. Clin. Pathol.; 34: 14-25, 1982

Macluean, G.D., Seehafer, J., Shaw, A.R.E., Kleran, M.W., Longenecker, B.M. Antigenic heterogeneity of human colorectal cancer cell 1ines analyzed by a panel of monoclonal antibodies. 1. Heterogeneous expres-

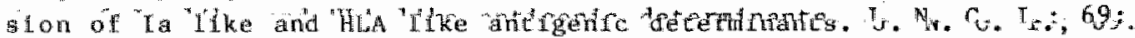
$357-364,1982$

Newland, R.C., Chapuls, P.H., Phells, M.T.* MacPherson, J.G. The relathonghlp of survtwal to staging and grading of colorectal carcinoma. Cancet; $47 ; 1424-1429,1981$

O"Daly, J.A., Cralg, S.H., Cebra, J.J. Localization of b markers, alpha-chain and SC of IgA in eplthelial cells lining Lieberkuhn crypts. J. Inumo 1 ; 106: $286-288,1971$

Poger, M.E., Hirsch, B.R., Lam, M.E. Synthests of secretory component by colonic reoplasms. Am. J. Pachol.; 82: 327-338, 1976 
Prehn, R.T. Analysis of antigentc heterogeneity within individual 3-methylcholantrene-induced mouse sarconas. J. N. C. T.; 45: 1039-1045, 1970

Qualhelm, R.E., Gall, E.A. Is histologic grading of colon carcinoma a Walid procedure? Arch. Pathol.; 56: 466-472, 1953

Rognum, T.O., Brandtzaeg, P., Orjasaeter, H., Elgjo, K., Hognestad, J. Immonohistochemical study of secretory component, secretory IgA and carcimoembryonic antigen in large bowel carcinomas. Pathol. Res. pract.; $170: 126-145,1980$

Rognum, T.0., Elgjo, K., Brandtzaeg, P., Orjasaeter, H., Bergan, A. Plasma carcinoembryonic antigen concentrations and immunohistochemical patterns of epithelial marker antigens in patients with large bowel carctnoma. J. Clin. Pathol.; 35: 922-933, 1982

Tourvile, D.R., Adler, R.H., Blenenstock, J., Tomasi, T.B. The human secretory immonoglobulin system: Immonohistological localtzation of A, secretory 'piece' and lactoferrin in normal human tissues. J. Exp. Med.; 129: $411-426,1969$

Meisz-Carrington, P., Poger, M.E., Lamm, M.E. Secretory Immunoglobullins in colonic neoplasms. Am. J. Patho1.; 85:303-316, 1976 
TUMOUR CELL HETEROGENEITY IN PRIMARY AND METASTATIC COLORECTAL CARCINOMA.

J.W. Arends, T. Wiggers, C. Verstijnen, F.T. Bosman, G.J.W. Swaen, J. Hilgers, E. Lennox and Z. Steplewski

6. 1. Summary

In order a) to assess the extent of phenotypic heterogeneity in terms of antigenic composition of primary colorectal carcinomas, b) to detect possible differences in antigenic composition between primary tumours and their metastases and c) to study the suitability of the use of antibodies as targeting-vehicles for the purpose of radiolmunodiagnosis and therapy, we studied a series of disseminated colorectal carcinomas for the presence of various colorectal (cancer) tissue associated-antigens, using a panel of conventional and monoclonal antibodies in an immunoperoxidase technique. Primary tumours expressed a multitude of antigens with marked intercellular heterogenelty; their metastases appeared to be no less heterogeneous in this respect. In general regional lymphnode metastases appeared to express the same antigens as their primary tumours, whereas haematogenous metastases tended to loose expression of some antigens. Since many antigens were found to be only focally expressed it may be necessary to use combinations af targeting-antibadies for effective visualization or toxification of the antigenically diverse tumour cell subpopulations in a given tumour. Immunoperoxidase studies are mandatory for the documentation of the cellular distribution of the antigens to be selected as targets for radioimunodiagnostic and therapeutic procedures.

Published in: Prot. Biol. Eluids; $31: 587-594,1984$ 
In recent years ruch attention has been focussed on the development of techniques to detect and localize malignat neoplasms by means of radiolabeled antibodies in combination with scintigraphic scanning methods (Mach et a1., 1974 . Primus and Goldenberg, 1980). It has become apparent, that the efficacy of these radioimmunodiagnostic procedures depends on several factors, such as the specificity (searle et a 1., 1981), affinity (Begent et a 1., 1980) and Ig class of the targeting-antibody, the accessability of the targetantigen (Moshakis et al., 1981), the amount of Eree targetantigen in serum and interstitial fluid, which potentially blocks tissue binding of the radio-labeled antibody /Primus and Goldenberg, 1980), and finally the choice of the isotope and the labeling procedure (Epenetos et al., 1982). In addition, a potential problem, to which hitherto very little attention has been paid, may be formed by the intercellular phemotypic heterogeneity in malignant neoplasms. Evidence has accumulated, that, by the time they can be clinically diagnosed, human neoplasms consist of subpopulations of cells with heterogeneous phenotypic features, including DNA-content (Vindelov et al.r 1980) growth rate (Butel et a1., 1977), antigenic composition (Prehn, 1970) and response to cytotoxic drugs (Barranco et al.. 1973), regardless of their generally assumed monoclonal origin. Also there are indications that peimary tumours consist of subclones of cells differing in metastatic potential (Fidier and kripke. 1977). It is not unlikely that in the evolution of metastatic tumours clonal selection takes place and therefore it is conceivable that the antigenic composition of neoplastic cells in metastases is more restricted than in the parental tumours. Such a phenomenon would be relevant to study with regard to the efficacy of application of radioimmunodiagnostic - and especially immunotherapeutic procedures, since these rely on the interaction of the antibody with as many tumour cells as possible. Therefore, the tissue distribution of the target-antigen of antibodies, considered for targeting purposes, has to be documented carefully, not only in respect of the possible presence of its determinant(s) in norma 1 tissue components, but also in connection with the extent of its expression in primary tumours and their metastases. So far most studies on tissue binding of targeting antibodies were performed on human cancer cells in tissue culture or xenografted in nude mice. Under these artificial conditions human tumours may not retain the original pattern of expression of cellular antigens (Rutzky and siciliano, 1982) and therefore immunocytochemical surveys of tumour tissue specimens are essential to fully document the pattern of antigen expression in the invivo situation.

we therefore studied the expression of various colorecta 1-(cancer)tissue-associated antigens in a large series of primary colorectal carcinomas as well as in their regional. lymphnode metastases and a few hematogenous metastases using 
a variety of conventional and monoclonal antibodies in an imunoperoxidase technique. Special attention was paid to: a) the extent of interceliular antigenic heterogeneity of primary colorectal tumours, b) the possible differences in antigenic composition between primary and metastatic tumours and cl Eimally the suitability of the applied antibodies as targeting vehicles for radioimmunodiagnostic and therapeutic purposes.

\subsection{Materials and methods}

\section{3 .1 . Material}

Al. tumour tissues were derived from patients with metastatic colorectal carcinoma collected in a multicentre prospective controlled trial, conducted from january 1979 till january 1982 and comparing the value of standard surgical procedures with a no-towch approach.

87 Cases with regional 1 ymphnode metastases and 15 cases. with hematogenous metastases were collected.

All tissue specimens were fixed in 4 neutral buffered formalin, embedded in paraffin and serially sectioned at 5 micron. 
6.3.2. Nature of the antibodies

conventional rabbit anti CeA and rabbit anti secretory component (SC) antibodies were purchased from Dako-immunoglobulins (Copenhagen, Denmark).

Designation, immunogen, target-antigen, and source of the used monoclonal antibodies are compiled in Table $I$.

\section{Table t.}

Colorectal (cancer) tissue reactive nonoclonal antibodies

\begin{tabular}{|c|c|c|c|}
\hline Designation & Iinmuragen & Target antigen & Source \\
\hline 1. a. PARIAM I & $\begin{array}{l}a \text { and } b \text {, plasma } \\
\text { membrane }\end{array}$ & $\begin{array}{l}\text { epitope on CEA } \\
\text { (1ike) molecule }\end{array}$ & $\begin{array}{l}\text { verstijnen et } \\
\text { al. }(1983)\end{array}$ \\
\hline b. ${ }^{X P C_{2}} / 12.1$ & $\begin{array}{l}\text { preparations of } \\
\text { colonic carci- } \\
\text { nomas }\end{array}$ & & $\begin{array}{l}\text { Finan et a } \\
(1982)\end{array}$ \\
\hline c. $\mathrm{CE}_{6} / 2 \mathrm{D}_{3,1}$ & $\begin{array}{l}\text { highily purified } \\
\text { CEA }\end{array}$ & & $\begin{array}{l}\text { Alderson (un- } \\
\text { published) }\end{array}$ \\
\hline 2. $\operatorname{YPC}_{2} / 44.3$ & $\begin{array}{l}\text { plasmamembrane } \\
\text { preparations of } \\
\text { colonic adeno- } \\
\text { carcinoma }\end{array}$ & mucin - Iike & $\begin{array}{l}\text { Finan et al. } \\
(1992)\end{array}$ \\
\hline 3. $1116 \mathrm{NS}_{19-9}$ & $\begin{array}{l}\text { Sw } 1116 \text { colonic } \\
\text { carcinoma cell } \\
\text { line }\end{array}$ & $\begin{array}{l}\text { monosialogan- } \\
\text { glioside }\end{array}$ & $\begin{array}{l}\text { Koprowski et } \\
\text { a. (1979) }\end{array}$ \\
\hline ․ wGHS $_{22-2}$ & $\begin{array}{l}\text { freshly isola- } \\
\text { ted gastric car- } \\
\text { cinoma cells }\end{array}$ & unknown & $\begin{array}{l}\text { Steplewski } \\
\text { Koprowski } \\
(1982)\end{array}$ \\
\hline $5.67 D_{11}$ & $\begin{array}{l}\text { human inilk fat } \\
\text { membranes }\end{array}$ & $\begin{array}{l}\text { of glycollpia } \\
\text { nature }\end{array}$ & $\begin{array}{l}\text { Hikens et al. } \\
(1982)\end{array}$ \\
\hline $6 . \mathrm{MH}_{2} / 6 \mathrm{D}_{4}$ & $\begin{array}{l}\text { HT-29 colon car- } \\
\text { cinoma cell line }\end{array}$ & blood group & $\begin{array}{l}\text { voak et ai. } \\
\text { (1980) }\end{array}$ \\
\hline
\end{tabular}


6.3.3. Iromunocy tochemistey

In order to evaluate the effect of routine tissue processing procedures on the preservation of the target-antigens the antibodies were initially tested on frozen sections of colorectal tumours, posteixed in acetone (10 min, 4 "C) and the staining result was compared with that of trypsinized parafin sections of the same tumours. With the exception of $Y \mathrm{PC}_{2} / 44.3$ all antibodies showed comparable patterns of immunoreactivity with these two procedures.

The target-antigen of $\Psi \mathrm{PC}_{2} / 44.3$ could be demonstrated in non-trypsinized parafein sections in a distribution analogous to that of frozen sections. The conventional antibodies were applied in the unlabeled peroxidase-antiperoxidase procedure, whereas the monoclonal antibodies were employed in an indirect peroxidase-labeled antibody procedure, using rabbit-antimouse Ig (Dako, Code nr. p169) as the second layer. The details of these procedures have been reported elsewhere (Acends et a 1., 1983 a t b).

\subsubsection{Scoring of immunoreactivity}

Immunoreactivity of all antibodies was semiquantitatively scored in primary tumours and metastases as positive (ower 80\% of the tumour cells expressing the antigen), negative, (less than 5 of tumour cells expressing the antigen) or focally positive (tumours showing reactivity in between 5 and $80 \%$ of the neoplastic cells).

\subsection{Results}

6.4.1. General characteristics of antigen localization and mode of expression

In the present study the antibody binding patterns were comparable in the primary tumours and in their metastases. Differences were noticed ondy with regard to their extent of expression. Conventional anti-CEA antibodies and the three monoclonal anti CEA antibodies showed analogous immunoreactivity in primary tumours as well as in metastases, their reaction products being localized in luminal cell debris and the apical plasma membrane, or diffusely in the cytoplasm but with increased concentration in the apex. The majority of the primary tumours and metastases showed CEA immunoreactivity in most cells 193.28 positive, 6.48 focally positive, 1,3 negative).

Anti-SC and the used monoclonal antibodies showed immunoreactivity diffusely in the cytoplasm, in the apical cytoplasm or on the plasma membrane. Antigen expression was significantly more often focal than was found for CEA 136.1 53.18 as against 6.48 for CEA)

6.4.2. Characteristics of antigen expression in primary tumours and regional lymphnode metastases

The difference in antigen expression between 87 primary 
colorectal carcinomas and their regional lymphnode metastases are given in table II.

\section{Tabie II}

Differences in antigen expression of primary colorectal carcimonas and regional 1 mphnode metastases

\begin{tabular}{|c|c|c|}
\hline Numbex of cases & $\begin{array}{l}\text { Wuber of antigers } \\
\text { differing in expres } \\
\text { sion pattern }\end{array}$ & $\begin{array}{l}\text { Dexcentage of cates } \\
\text { diftering in exples- } \\
\text { sion putwern }\end{array}$ \\
\hline
\end{tabular}

$\begin{array}{ccc}34 & - & 39.0 \\ 28 & 1 & 32.3 \\ 15 & 2 & 17.2 \\ 8 & 3 & 9.2 \\ 2 & 4 & 2.3\end{array}$

It is clear that in the majority of cases (71.38) no differences in antigen expression or a difference for only one antigen occurred . Qualitative differences (positive to negative or vice versa) accounted for only $10 \%$ of the changes. In all other cases the change was from positive to Eocally positive, focally positive to negative or vice versa (table III).

\section{Table III}

Pattexn of altexation in antigen expression in primary colloractaj carclnoma and regional Iymphnode metastases 
If changes from focally positive to positive and from negawive to focally positive are considered to indicate increased antigen expression. 15 primary tumours expressed antigens more extensively than their lymphnode metastases, whereas in 23 cases the lymphnode metastases expressed antigens more extensively than their parental tumours.

The remaining 15 cases showed both phenomena simultaneousiy for different antigens. Concordance and disordance for the individual antigens in primary tumours and their lymphmode metastases are summarized in table IV.

Table IV

Concordance of antigen expression in primary colorectal carcinomas and regional lymphnode metastases

$\begin{array}{cccc}\text { percentage } & \text { number of } & \text { expression } & \text { expression in } \\ \text { of } & \text { differing } & \text { in primary } & \text { metastases } \\ \text { concordance } & \text { observations } & \text { more than } & \text { more than } \\ & & \text { metastases } & \text { primary }\end{array}$

$\mathrm{SC}$

78.2

19

9

10

CEA

98.8

1

0

1116 NSS $_{19-9}$

73.6

23

8

15

WGHS $_{22-2}$

78.2

19

10

9

$\mathrm{YPC}_{2} / 4.3$

78.2

19

11

8

$67 \mathrm{D}$

87.4

11

5

6

It is clear, that concordance for the individual antibodies was the predominant pattern and that, where differences were observed, primary tumours showed more extensive as well as more limited patterns of expression compared with their metastases. 
6.4.3. Characteristics of antigen expression in primary tumours and distant and/or hematogenous metastases

The number of available hematogenous metastases that could be studied was small (table v).

Table $\mathrm{v}$

Antigen differences noted between primary colorectal carcinomas and organ metastases

site of antigen aifference noted
metastases motiterence noted

Dukes $D$

patients

1. 1 iver

2. 1iwer

3. hilus of speen

\section{metastiases}

developed

during follow-up
4. omentum

5. praegacxal region

6. right adnex

7. $\operatorname{skin}$

9. Liwer
$\mathrm{YPC}_{2} / 44.3$ from focal to negative

SC and WGHS 2 from EOCal to negative
WGHS $_{22-2}$ from negative to Eocal
WGHS $_{22-2}$ and $11.6 \mathrm{NS}_{19-9}$ from focal to negative SC from focally positive to negative avitopsy

cases
9. Iiver

10. $11 v e x$

11. liver theres

12. 1iver + lung

13. brain

14. lung

15. ovary

\section{1. detary}

i. dem

10)

1. Hen

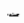


It is clear, that where differences in antigen expression were noticed organ metastases tended to display less antigens. This phenomenon was most strikingly observed in liver metastases, especially in regard of $\mathrm{SC}$.

\subsection{Discussion}

Two technical limitations may be relevant to the validity of the results of the present study. The first concerns the possibility of sampling error. For practical reasons only one block of the primary tumour and of the metastases was selected for immunocytochemical staining. Conceivably studying multiple blocks might result in even more extensive variability in the expression of antigens in primary tunours. However, of a limited number of primary tumours an extensive survey was performed on multiple sections and comparing these results with those obtained on one representatire block only did not reveal significant differences.

of the metastatic localizations also only one block was studied, which often contained only a 1 imited amount of tumour tissue. Another potential source of sampling ercor is the fact that only a limited number of hematogenous metastases was available. Our impression, that hematogenous metastases tend to display a moxe 1 imited pattern of antigen expression than their primary tumours therefore needs to be reconfirmed in a much larger series.

A second technical limitation is related to the fact that most of the available hematogenous metastases were obtained at autopsy. Due to autolysis immunohistochemical profiles of autopsy material might not completely reflect the in wivo situation. Based on our experience with the immunoreactivity of intestinal antigens in autopsy specimens of intestinal mucosa in comparison with surqical specimens (unpublished observations), however, it is our impression that autolysis is not a significant factor in the reduction of antigen expression, which we observed in hematogenous metastases.

We therefore feel that, even if these limitations are taken into consideration, the conclusion that primary colorectal carcinomas as well as their regional lymphnode metastaseg display marked intercellular phenotypic heterogeneity is wartanted. At least two mechanisms may be involved in the generation of phenotypic heterogeneity in metastatic lesions. Firsty it is conceivable that metastases do not originate from emboli of single tumour cells but rather from c.lumps of tumour cells with varying phenotype. Secondly, it. is not unlikely that metastasising tumour cells are relatively undiferentiated and may possess pluriform differentiating potential (Fidler and Hart, 1982). Whether one of these two mechanisms or even a combination of both is responsible for the observed phenotypic heterogeneity in metastases remains to be elucidated. 
Whether distant metastases really tend to loose expession of differentiation antigens, such as $\mathrm{SC}$, remains to be established in a larger series of cases. Though this phenomenon would be difficult to explain in terms of increasing heterogeneity of metastases during the course of their development, selective loss of immunoreactivity has been reported (Atkinson et a 1., 1982), however, not especially in the liver, where metastases in our study showed a remarkable loss of the antigens studied.

The finding of an over-all conservation of antigen expression in lymphnode metastases, and for most antigens also in distant metastases, confirms that in principle immunotargeting procedures might be of use for diagnosis and treatment of human tumours. The heterogeneity in expression of different antigen however, deserves ample consideration. Most of the antibodies employed show a focal distribution pattern of immunoreactivity in the primary tumour as weli as their metastases, implying that immonotargets as a rule are not to be expected to be expressed on all cells of the malignant neoplasm. of the target-antigens studied, CEA appeared to be most constantly expressed by the cells of both primary and metastatic tumours, though its distribution in normal intestinal mucosa and its release into body fluids are disadvantages for use in immunotargeting procedures.

For reliable visualization or effective toxification of the antigenicaliy diverse tumour cell populations in a given tumour it will probably be necessary to use combinations of immunotargeting vehicles so chosen that the total of its respective target-antigens cover most of the areas of tumour. growth. In the documentation of the distribution of these target-antigens and the subsequent selection of antibodies appropriate for use in radioimmunodiagnostic and therapeutic procedures immunocytochemical surveys are mandatory. 
Arends, J.W., Gronlowski, M.K., De Koning Gans, H.J., Bosman, F.T. An

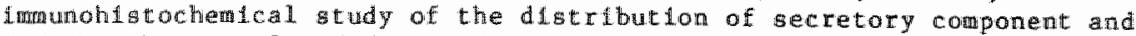
IgA In the normi and diseased uterine mucosa. Int. J. Gym. Pathol.; 2: $171-181,1983 a$

Arends, J.h., Verstjuen, C., Bosman, F.T., Hilgers, J. and Steplewskl, 2. DLstribution of monoclomal antibody-defined monosialoganglioside in normal and cancerous human tissues: an immoperoxidase study. Hybridoma; $2: 219-229,1983 b$.

Atkinson, B.F", Ernst, C.S., Herlyn M., Steplewski Z., Sears, H., Koprowsk1 H. Gastrolntestinal cancer-associated antigen in immunoperoxidage assay. Cancer Res. $42: 4820-4823,1982$

Marranco, S.C., Drewlnko, B., Humphrey, H.M. Differential response by human melanoma cells to 1.3-(bls)-(2-chlormethyl)-1 nitrosourea and blednyctn. Mutat. Res.; 19: 277-280, 1973

Begent, R.H.J., Stanway, G., Jones, B.E., Bagshawe, K.D., Searle, F., Jewkes, R.F., Vernon, P. Radiolmunolocallzation of tumours by external scintigraphy after administration of 1311 antibody to human chorionic gonadotrophln: prelfminary communtcation. J. Royal Soc. Med.; 73: 624630,1980

Butel, J.S., Dudley, J.P., Medina, D. Comparison of the growth propertles in vitro and transplantablilty of contlnuous mouse mammary turour cell Iines and clonall derlwatives. Cancer Res.; $37:$ 1892-1900, 1977

Epenetos, A.A.A., Mather, S., Granowska, M., Nimmon, C.C., Hawkins, L.R., Britoon, K.E., Shepherd, J., TaylorPapadimlerlou, J., Durbin, H., Malpas, J.S. Targeting off lodine-123-labelled tumour assoclated monoclonal antibodies to ovarian, breast, and gastrointestinal tumours. Luancet; 999 , november 1982

Fidler, I.J., Hart, I.R. The development of blological diversity and metastatic potential in malignant neoplasms. Oncodev. B1ol. Med.; 4 : 161176,1982

Heller, I. . Kripke, M.L. Metastasis results from preexisting varlant calls withen a malignant tumour. Sctence; 197: 893-895, 1977

Finan, P.J., Grant, R.M., Matcos de, C., Takel, F., Berry, P.J., Lennox, E.S., Bleehen, N.M. Immunohistochemical techniques in the early screening of monoclonal antibodies to human colonic eplthelium. Br. J. Cancer; $46: 917,1982$

Goldenberg D.M., KIm, E.E., Deland, F.H., Bennet, S., Primus F.J. Radiom immunodetection of cancer with radloactive antibodies to carcinoembryonic antigen. Cancer Res.; 40:2984-2992, 1980

Hilkens, J., Buys, F., Hilgers, J., Hageman, Ph., Sonneberg, A., 
Koldowsky, U., Karanda, K., v. Hoeven, R.P., Feltkanp; C., vid, RHn, I.M. Monoclonal antibodies against human milkat globule membranes detecting differentiation antigens of the mamary gland. Prot. Blol. Flulds; $29: 813-826,1982$

Koprowski, H., Steplewski, 2 , Mitchell, K., Herlyn, M., Hexlyn, D, and Fuhrer, P. Colorectal carcinoma antigens detected by hybridoma antibodies Som. Cel1. Genet.; 5: 957-972, 1979

Mach, J.P., Canel, S., Merenda, C., Sordat, B., and Ceroulni, J.C. In vitro localization of radiolabeled antibodies to carcinoembyonic antigen in human coloncarcinoma grafted into nude mice. Nature; 248 : $704-706,1974$

Moshakis, V., Mclhinney, A.J., Raghavan, D., Neville, A.M. Localliation of human tumour xenografts after 1.v. administration of radiolabeled monoclonal antibodies. Br. J. Cancer; $44: 91-99,1981$

Prehn, R.T. Analysis of antigenic heterogeneity within lndividual 3-methylcholanthrene-induced mouse sarcomas. J. N. C. I.; 45: 1039-1045, 1970

Rutzky, L.P., Siclliano, M.J. Various isoenzyme gene expression patterns among human colorectal adenocarcinoma cell lines and tissues. $I_{*} N_{*}$. C. I.; $68: 81-90,1982$

Searle, F., Boden, J., Lewis, J.C.M., Bagshaw, K.D. A human choriocarcinoma xenograft in nude mice; a model for the study of antibody locallzathon. Br. J. Cancer; $44: 137-144,1981$

Steplewski, Z. and Koprowski, H. Monoclonal antibody development in the study of colorectal carcinoma-associated antigens. Methods Cancer Res.; $10: 313,1982$

Verstijnen, C., Moerkerk, P., Arends, J.W., HIlgers, J., and Bosman, F.T. Comparison of conventional ant $1-C E A$ antiserum with monoclonal CEA reactive antibody. Abstract. Proc. Dutch Fed. Meeting; 429, 1983

Vindelov, L.L., Hansen H.M., Christensen, J. Clonal heterogeneity of smal1-ceil anaplastic carcinoma of the 1 ung demonstrated by flow-cytometric DNA analysis. Cancer Res.; 40: 4295-4300, 1980

Voak, D., Sacks, S., Alderson, T., Takel, P., Lennox, E., Jarvis, $\mathcal{X}_{*}$, Milstein, C., Darnborough, J. Monoclonal anti-A from thylurd-myeloma: evaluation as a blood grouping reagent. Vox Sang; $39: 134-140,1980$ 
EPTLOGUE

7.1. Introduction

The identification and localization of antigens in cancerous tissues entallis apparent perspectives, but also is subject to certain Limitations. In this epilogue both Iimitations and perspectives of antigen expression at the tissue level will be discussed in the context of the data obtained in our investigations. At the end of the chapter possible ways to alleviate the limitations of antigen expression studies are suggested and finally the perspectives of study of ancigen display in respect of a cell-origin-related classification are indicated.

7.2. Summary of the results of the study

In Chapter I the potential value of tissue antigen expression for the classification and characterization of primary tumours and metastatic lesions as well as for the assessment of grade of malignancy of colorectal neoplasms is outlined. Also, the problem of antigen-specificity and the phenomenon of intercellular phenotypic heterogeneity of antigen display are discussed as possible impediments in the establishment of significant associations between antigen expression and tumour type or biological behaviour.

The studies presented in this thesis emphasize the interrelation of these important aspects in the study of antigen expression, especially in connection with secretory component (SC) and the monoclonal antibody 1116 NS 19-9 defined monosi.aloganglioside (GICA) in colorectal carcinomas.

In chapter II the potential value of GICA for the diagnosis of colorectal carcinomas is addressed because it initially was considererd a colorectal carcinoma-specific antigen. By immunoperoxidase studies on mildly fixed frozen tissue sections and routinely fixed parafin-embedded sections the antigen was shown to be present in many glandular epithelial cells and variety of tumours of other than gastrointestinal tract origin. The results of the study indicate that GICA cannot be considered a colorectal carcinomaspecific antigen. Consequently, its value as a diagnostic tool in these tumours is very limited.

Chapters III, IV and $V$ deal with the search for associations of GICA and SC expression with clinicopathological variables known to be of prognostic significance in colorectal. carcinomas, such as stage of tumour extension and histological grade. In addition the immunoreactivity status of both antigens was directly correlated with data on patient survival. The mode of GICA expression did not appear to be correlated with stage or grade of colorectal carcinomas (chapter III), nor with other parameters studied such as lo- 
calization, DNA content and percentage of S-phase cells. The antigen demonstrated a focal, heterogeneous expression pattern in about half of the carcinomas and was present on most tumour cells in only about 100 of the investigated tumours. Patients with uniformly GICA positive tumours tended to show shorter survival periods than patients with tumours displaying other types of GICA expression. This trend, however, did not reach statistical significance (Chapter IV). Although this finding suggests a possible association between the presence of GICA and a more aggressive behaviour. it should be interpreted with caution because of the small number of GICA uniformly positive cases in the series, the relatively short follow-up periods and certain methodological limitations. One such limitation was formed by the circumstance that for $\mathbb{i m m}_{\mathrm{m}} \mathrm{m}$ istochemical studies in the majority of cases only one block of tumour tissue was available. In a study on multiple sections of a limited number of carcinomas scoring of unlformly positive and negative tumours appeared to be rather reliable on account of one section. Carcinomas displaying GICA in a focal, heterogeneous pattern, however, appeared to show a wide variation in the number of immunoreactive cells in various areas of the tumour. Therefore exact scoring of the percentage of positive cells in heterogeneous tumours in one section appeared to be injustifiable to acquire a correct impression on the number of immunoreactive cells in the tumour as a whole. Thus heterogeneity in GICA expression introduced a source of sampling error in our experimental design which prevented us from the execution of further studies on the survival periods of patients with tumours in which a more accurate immunoreactuvity scoring was performed. That the phenomenon of interceliular phenotypic heterogeneity interferes with studies attempting to establish associations of antigen expression with other clinicopathological variables is even more explicitly exemplified by our data on the immunoreactivity of $S C$ in colorectal tumours (Chapter V). Carcinomas with uniformly positive SC expression frequently occurred in the groups of low-stage and low-grade carcinomas, whereas the reverse trend was observed in SC negative tumours. The substantial proportion (36\%) of SC heterogeneous tumours, however, failed to show any correlation with stage and grade. In addition, inclusion of the group of SC heterogeneous carcinomas in the analysis of patient survival data obscured the significant difference in survival observed between patients with SC uniformly positive and negative tumours. Thus, although our data establish SC expression as an independent parameter of prognostic relevance in colorectal. carcinona, the sensitivity of the parameter was reduced due to the occurcence of a group of tumours with heterogeneaus $\mathrm{SC}$ expression.

In Chapter VI a study on the extent of heterogeneity in antigen expression of primary and metastatic colorectal carcinomas using a panel of colorectal carcinoma reactive antibodies is reported and at the same time the hypothesis, 
that clonal selection during the process of metastasis might be reflected in diferences in antigen display between parental and metastatic tumours was tested in connection with a possible interference of such a phenomenon with immuno targeting procedures. The antigenic composition of primary colocectal. carcinomas as well as their metastases appeared to be diverse. Lymphnode metastases generally retained the antigenic profile observed in the parental tumours, whereas haematogenous metastases tended to loose expression of some antigens. A definite reflection of clonal selection in metastasis on antigen display, however, was not obtained for the studied antigens. The extensive heterogeneity in expression of most antigens necessitates the use of combinations of targeting-antibodies for effective visualization or toxiEication of tumour cells in immunotargeting procedures.

In sumary, the important messages of our studies are, that

a) inmunocytochemical characterization of antigen expression on a variety of different tissues is an essential step in the exploration of antigen-specificity and the selection of target-antigens suitable for immunotargeting procedures.

b) determination of tissue expression of certain antigens can be of prognostic value, although the occurrence of heterogeneity in antigen display may attenuate the sensitivity of such prognostic significance.

\subsection{Possible alleviating approaches to limiting aspects}

7.3.1. Antigen-specificity

Concerning the 1 imitations posed by antigen-specificity two main aspects deserve consideration: the apparent lack of colorectal carcinoma-specific antigens and the procedures involved in the determination of antigen-specificity.

In spite of five years of intensive research with monoclonal antibodies the existence of tumour-specific antigens in human colorectal carcinomas is still unproven. This may be partly due to the relatively aselective immunization procedures so far used in the generation of monoclonal antibodies. An approach, in which some form of prior antigen selection has been applied might be more rewarding. Selection of membrane glycoproteins of colorectal cancer cells through lectin affinity or lipid extraction followed by further selection through thin-layer chromatography, for example, might increase the chance of obtaining tumourspecific antibodies. Alternatively, the immune response in recipient animals could conceivably be more restricted to tumour-specific antigens, when these animals could be rendered tolerant to normal colonic mucosal antigens by repeated low-dose administration with extracts of normal colonic mucosa followed by immunization with extracts of coIonlc cancer tissue. 
In most biomedical research institutes antigen-specificity is often determined on cancer celis in tissue culture. Although this exploration is of apparent value as a first screening on antigen-specificity it should be complemented with similar studies on a wide variety of fresh or fixed tissues. Cultured cancer cells probably represent only a limited selection of the cells present in the original tumours and may in addition loose some characteristics of the originall tumour during cultivation, whereas fresh tissue can be expected to express the almost full range of antigens present in the in vivo situation. Therefore close cooperation between basic scientists and surgical pathologists would greatly enhance and facilitate appropriate antigen specificity testing.

\subsubsection{Phenotypic heterogeneity}

That phenotypic heterogeneity of antigen display forms a major obstacle in studies aimed at establishing associations between antigen expression and other clinicopathological variables has been shown in the literature and explicitly in our investigations. Especially studies relying on the comparison of two variables with intrinsic heterogeneity are liable to be flawed by a simple categorization of either of these variables. This situation occurs in the correlation af antigen expression with histological grade (Qualheim and Ga11, 1953), where simple aver-all classification of tumours into one grade and one type of antigen expression may obscuce a potential correlation between the two variables at the level of the individual cell.

There are two possible ways to diminish the interference of antigenic heterogeneity in the establishment of associations between antigen expression and other prognostic parameters.

Firstly, since the survival period of individual patients can be acurately determined, correlation of antigen expression with survival in patients only leaves the variable nature of the parameter of antigen display. This type of potentially rewarding studies, however, hitherto has been scarcely conducted due to the reliance on a large series of clinically carefully documented patients, requiring a close multidisciplinary approach of clinicians and pathologists.

secondy, the attenuating effect of antigenic heterogeneity on the sensitivity of antigens with value as single prognastic indicators conceivably could be largely compensated for by application of a number of such antigens in a multivariant analysis on progmosis. Such studies, however, require very large series of patients for adequate statist cal evaluation and therefore generally depend on multicentre cooperation. Since more aggressive behaviour of cumour cells is generally associated with loss of differentation antigens, it is of interest to search for and include antigens, which appear to be expressed in the more immature tumour types only in a multivariant analysis. Our data suggest that GICA may be an antigen of such nature. 
The phenomerom of intercellular heterogeneity in tum mours itself. however, is of interest to investigate in relation to more fundamental aspects of development and progression of neoplasia. In this context studies combining Cell kinetics las determined by autoradiography with H-thymidine incorporation or by flow cytometry) with antigen expression might be rewarding to acquire information on the nature and significance of behaviour of neoplastically transformed tissue. This becomes even more pertinent in the ingt of the observation, that during their evolution the antigen expression of tumours may be liable to alteration (Baylin et al., 1978).

7. 4. Future perspectives of antigen expression studies in cell-origin-related classification of colorectal carcinoma

On the basis of the concept of maturation of neoplastically transformed cells in a particular stage of differentiation Eollowed by clonal expansion of the arrested cell type. lymphologists nowadays have set out to classify malignant lymphomas according to the normal lymphoid cells to which they are related (Lukes et al., 1978; Stein, 1978). This approach has led to the distinction of neoplastic varieties within a group of morphologically indistinguishable tumours with prognostic and therapeutic implications.

Research in this field has been stimulated by the availability of a scala of in vitro functional tests for lymphocytes of different 1 ineages and of distinct stages of maturation developed by immunologists. This set of tests could serve as a backbone for the comparison of antigen expression in normal. Iymphocytes and their purported derivative neoplasms. The incorporation of the functional check in this approach has led to the recognition, that many questions regarding the origin and Eunction of neoplastic cells can be answered by comparison of their antigen expression profile with normal cells (for review see Mann et al. 1979). In this context the exquisitely rapid delineation of monoclonafl antibody defined differentiation antigens in lymphocytes of the $T$ and $B$ lineage may be indicative (Kung et $1 . ; 1979$; Reinhertz t a . , 1979; Brooks et al., 1980).

If the results of these investigations in the field of mal Ignant lymphoma research may be transferred to other neoplasms, this would imply that in regard of the typing and classification of colorectal cancer study of antigen expression possibly encompasses the most promising perspectives. Certain conditions, however, have to be considered in studies of this type in colorectal cancer.

Firstly, a cell-origin-related approach, ideally, should be based upon a model of the derivation and differentiation of the main cell types of colorectal mucosa, but in this area of cesearch certain controversies exist. At present the weight of balance of experimental data favours the 
unitarian concept of origin of all intestinal epithelial cell types (Andrew et a 1., 1982). Kinetic experinents bave delineated their interrelations and stages of development and maturation in the mouse colorectal mucosa, as represented schematically in fig. I chang and Leblond, 1971 a and b). With the uncertainty, whether these data are applicable to the human situation, this scheme could be used as at present the most acceptable concept of the interrelation in development and maturation of colorectal epithelium. Secondly, there are ample indications from experimental and clinical data, that colorectal tumours do not allow a distinct classification according to one single type of differentiation, since during their evolution several lines of differentiation may be expressed in the clones af one tumour or even in individual tumour cells. Cox and Pierce (1982) elegantly showed in an experimental rat colonic adew nocarcinoma of mixed composition, that the original display of differentiational characteristics reappeared during the development of a transplant tumour obtained after single tumour cell transplantation. "Stem cell" tunours displaying a variety of morphological and functional features have been described (Petrelli et al , 1981; Damjanov et al., 1983). Also mixed tumours composed of adenomatous and carcinoid elements are we 11 known varieties featuring amongst colorectal carcinoids (Hernandez and Reid, 1969; Hernandez and Fernandez, 1976). As already mentioned colloid carcinomas frequently express lysozyme and neuroendoctine granules in addition to abundant mucus production (Arends and Bosman, 1983). Finally there are indications that in commonly occurring colorectal tumours (adenocarcinomas), SC inmunoreacti$\checkmark i t y$ and mucus production frequently coincide (Arends et al., unpublished observations, see picture on the cover of this thesis).

Thirdly, a limitation is formed by the circumstance that in respect of colonic epithelial cells no in witro functional tests have been developed to ascertain the $1 \mathrm{r}$ stage of maturation and functional abilities. Therefore, in respect of colorectal carcinomas a cell-origin-rellated classification only relies on the comparison of the antigen expression profile of normal and neoplastic epithelium.

one way to attain the goal of obtaining antigens reflecting distinct stages of maturation and function would be to generate monoclonal antibodies by means of immunization of reciplent animals with colonic epithelial cells of distinct stages of maturation. Since goblet cells and columar cells maturate and differentiate during the course of migration from the crypt base to the mucosal surface. selection of celis originating from diferent heights along the cryptal surface as immunizing agents would seem to be a rational approach to obtain antigers, which might reflect a particular stage of matution. Techniques to acquire such a selection momentarilly are avallable (Roediger and Truelove. 1979). It is conceivable, that on the basis of this approach "developmental" antigens can be detected on colonic epithe- 

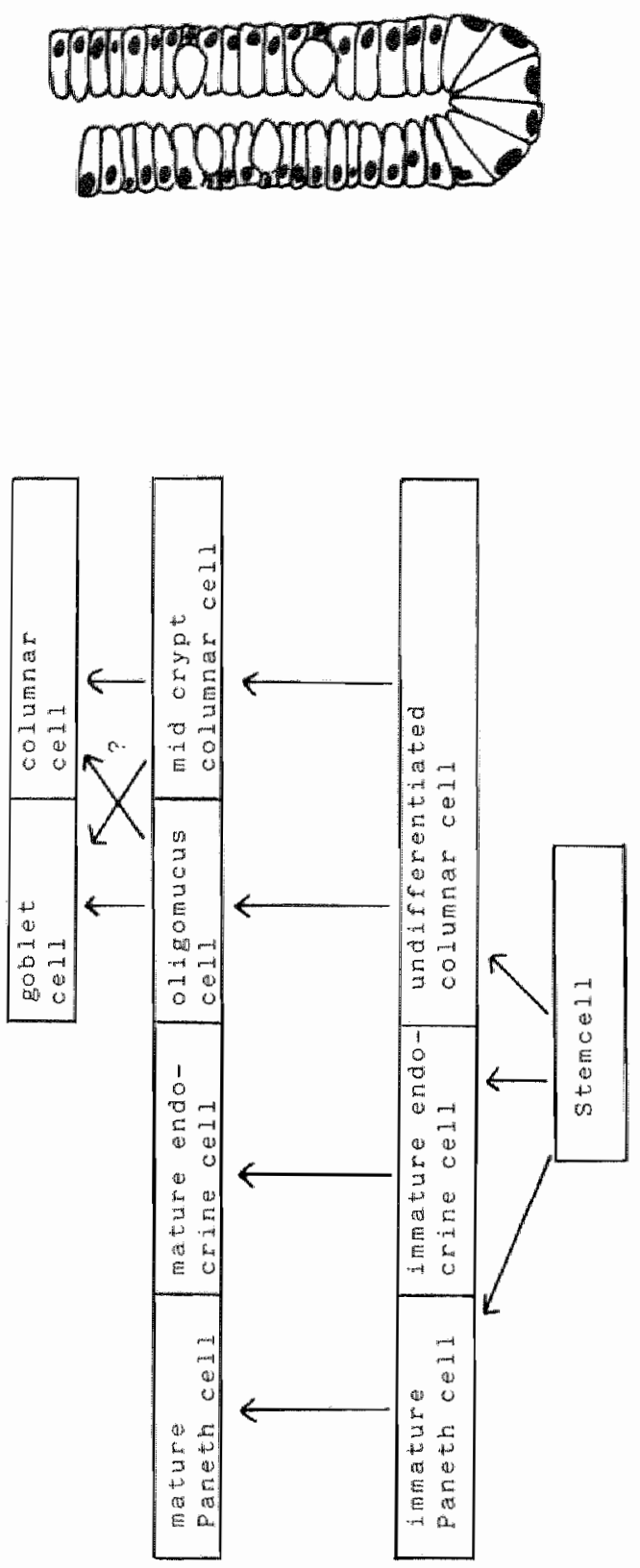
lial cells and their derivative neoplasms as e.g. has been the case with $\mathrm{T}$ lymphocytes in the acquistion of monoclonal antibodies of the okT series.

A systematic mapping of the expression of the secretory products and "developmemtal" antigens of the main colonio epithelial cell types in colorectal carcinoma could, therefore, given the above limitations, provide a spectrum with varying combinations or single expression of these antigens, from which in the context of the concepts outlined above the extent of pluripotency of the various colonic epithelial cell types in their respective stages of development and maturation could be read and according to which colorectal carcinomas could be posituoned in a cell-origin-related scheme, as tentatively drawn in fig. 2.

7.5. Concluding remark - value of "developmental" antigens. In this thesis the diagnostic and prognostic value of antigen expression in colorectal carcinomas has been evaluated against the background of the present limitations formed by the lack of antigen-specificity and the phenotypic heterogeneity of antigen expression.

From the literature and experimental data presented the perspectives of the study of antigen expression in colorectal carcinomas may seem rather futile. To this effect, however, one major point has to be made. Our study concentrated on "differentiation" antigens, but it should be realized, that the inclusion of "developmental" antigens may be crucial in the evaluation of the experimental and clinical value of tumour antigens in view of the notion, that many tumours, and most notably the poorly and undifferentiated variants, which generally behave most aggresslvely in patients and therefore pose a great challenge to medical. scientists, do not express features and associated antigens of differentiation. Thus by studying "differentiation" antigens exclusively many tumours will remain refractory to efforts to characterize their behaviour in biological terms and also will be resistent to diagnostic and therapeutic procedures through detection and manipulation of antigenic a isplay.

Therefore it should be apparent that the search for "developmental" antigens would greatly enhance the perspectives of the study of antigen expression in colorectal carcinomas. 


\begin{tabular}{|c|c|c|c|}
\hline 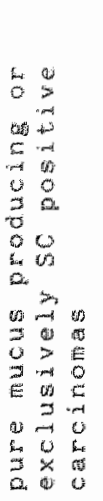 & 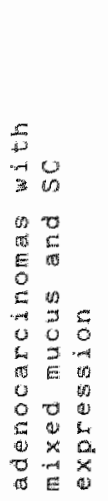 & 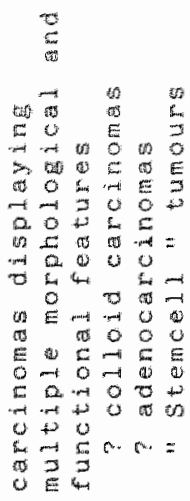 & 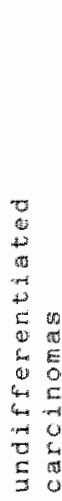 \\
\hline
\end{tabular}

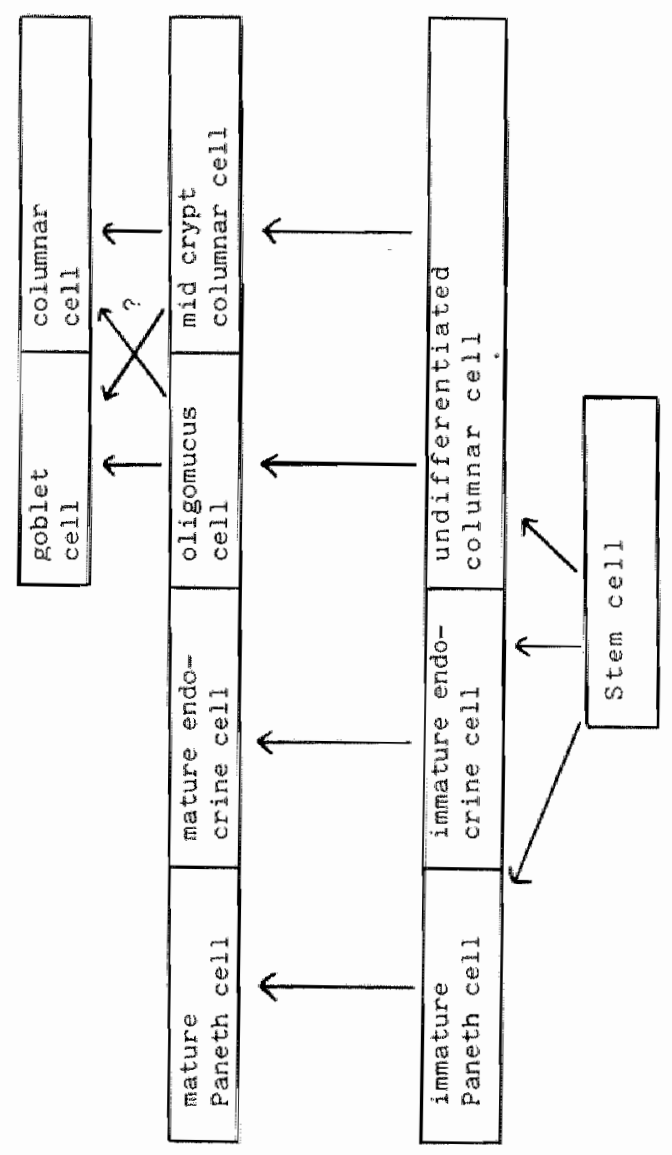


Andrew, A., Kramer, B., and Rawdon, B.B. The embryonic ordin of endocrine cells of the gastrointestinal tract. Gen.Comp. Endocilnol.; $47: 249-265,1982$

Arends, J.W. and Bosman, F. T. Signet-ring cell carcinoma of rectur. Histopathology; $7: 135-136,1983$

Baylin, S.B., Welsburger, W.R., Eggleston, J.C., Mendelsohn, G., Beaven, M.A., Abeloff, M.D., Ettinger, D.S. Vatiable content of histaminase; 1-dopa decarboxylase and calcitonin in smal1-cell carcinoma of the lung. New Eng1. J. Med. 299: 105-110, 1978

Brooks, D.A., Beckman, I. Bradley, J., McMmara, P.J., Thoma, M.E. and Zola, H. Human lymphocyte markers defined by antibodies derived from somatic cell hybrids. I. Hybridomas secreting antibody agalnst a marker specific for human B lymphocytes. Clin. Exp.Immunol.; $39: 477,1980$

Chang, W. W.L., Leblond, C.P. Renewal of the eptthellal cells in the descending colon of the mouse. I. Presence of three cell populations vacuolated - columnar, mucous and argentâfetr. Am.J.Anat.; 131 : 73-100, 1971 a

Chang, W.W.L., Leblond, C.P. Renewal of the eptthelial cells in the descending colon of the mouse. II. Renewal of argentaffin cells. Am.J.Anat.; $131: 101-110,1971 \mathrm{~b}$

Cox, W.F. and Plerce, G.B. The endodemal origln of the endocrine cells of an adenocarcinoma of the colon of the rat. Cancer; 59: 1530-1538, 1982

Damjanov, I., Amenta, P.S. and Bosman, F.T. Undifferentiated carcinoma of the colon contalning exocrine, neuroendocrine and squamous cells. Vi.rch.Arch. (pathol.anat.); $401: 57-66,1983$

Hernandez, F.J., Reld, J.D. Mixed carcinold and mucus-secreting intestinal tumors. Arch. Pathol.; 88: 489-496, 1969

Hernandez, F.J., Fernandez, B.B. Mucus-secreting carcinald tumor in a colonic diverticulum: Report of a case. Dis. Colon \& Rectum: 19:63-67, 1976

Kung, P.C., Goldsteln, G., Relnherz, E.L., Schlossana, S.F. Monoclonel. antibodies defining distinctive human T-cell surface antigens. Siclence; $347-349,1979$

Lukes, R.J., Parker, J.W., Taylor, C.R., THndle, B.H, Cramer, A.D., Lincoln, T.L. Inmunologic approach to non-Hodgkin's lyaptionas and rellated leukentas: Analysis of the results of multiparameter studies of 425 cases. Sem. Hemato1.; 15: $322-351,1978$ 
Mann, R. B. Jaffe, W. E. Berard, C.W. Mallgnant Lymhomas - a conceptual under tanding of morphologlc diversty. Am. J.Pathol.; $94: 105-192,1979$

Petrell1, H. Tetangco, E* Relit, J.D. Carcinoma of the colon with undfferentated, carcinoid, and squamous cell features. Am.J.Clin. Pathol.; $75: 581-584,1981$

Qualhelm, R.E., Gall, E.A. Is histologic grading of colon carcinoma a valld procedure? Arch , Pathol.; $56: 466-472,1953$

Relnherz, E.L., Kung, P.C., Goldstein, G., Schlossman, S.P. Further characterizaton of the human inducer $\mathrm{T}$ cell subset defined by monoclonal antibodies. J. Kmouno $1, ; 123: 2894,1979$

Roediger W.E. W. and Truelove S.C. Method of preparing isolated colonic epl thellal cells (colonocyces) for metabolic studies. Gut 20: $484-488$, 1979

Steln, H* The 1mmunologic and Immunocthemical basis for the Klel classification; Malignant lymphomas other than Hodgkin's disease. (E. Uehlinger, Ed.) Springer-Verlag Berlin, p. 529-656, 1978 
Dit proefschrift behandelt, aan de mand van een reeks immnocytochemische onderzoekingen, enkele mogelijkheden en beperkingen van het onderzoek naar de expressile van macromoleculen (antigenen) in weefsel. Het ondergoek werd verricht op weefsel van patienten met colorectaal carcinoom.

Hoofdstuk I geeft een overzicht van de relevante literatumgegevens betreffende de expressie van antigenen in colorectaal carcinoonweefsel. Het schetst het algemene kader" warin de immunocytochemische onderzoekingen hebben platsgevonden. De conclusie uit dit literatuuroverzicht is, dat het bepalen van antigeen expressie patronen in tumorwefsel van warde kan zijn bij het karakteriseren en classificeren wan primaire tumoren en hun metastasen (diagnose). Tevens mag op grond hiervan worden verwacht, dat de aan- of afwezigheld van bepaalde antigenen in tumoren van woorspellende warde kan zijn voor hun gedrag bij patienten (prognose). Deze potentiele diagnostische en prognostische warde wordt echter ernstig beperkt door twee factoren: antigenen, specifiek voor normal of neoplastisch colorectaal weefsel ontbreken en bovendien vertonen turnoren in hun antigene samenstulling een anzienlijke heterogeniteit.

Hoofdstuk II vermeldt de resultaten van een onderzoek nar de specificiteit van het "Gastro-Intestinad-Cancer-Associated antigeen (GICA)". Volgens voornamelijk op serologisch onderzoek en studie van cellijnen gebaseerde gegewens zou dit antigeen eem distributiepatroon vertonen, dat beperkt is tot carcinomen en foetal weefsel van de tractus digestivus. ons onderzoek nar het voorkomen van GICA met behulp van een i.rmunoperoxidase techniek bracht echter an het licht dat dit antigeen op vele epitheel- en carcinoomsoorten, buiten het maag-darmstelsel, voorkomt. Met dit onderzoek wordt onderstreept dat het verrichten van immunocytochemische analyse op vers en gefixeerd materiaal van belang is in heto kader van specificiteitsonderzoek van antigenen.

Hoofdstuk III behandelt een onderzoek nar correlatiles tussen het expressiepatroon van GICA in colorectale carcinomen en enkele prognostisch belangrijke clinicopathologische variabelen, zoals de uitgebreidheid van de tumor en de histologische differentiatiegraad. Wij konden geen asociatie tussen het expressiepatroon van GICA en de geteste variabelen aantonen. Daarom mag worden verwacht dat het expressiepatroon van dit antigeen in colorectale carcinomen geen aanwijzing geeft omtrent het gedrag van deze tumoren bij patienten.

Hoofdstuk IV beschrijft een onderzoek dat deze verwachting nader bevestigt. Uit dit onderzoek bleek dat geen signifj- 
cante correlatie arwijsbar is tussen het GICA expresiepatroon en de overlevingsduur wan patienten met colorectal carcinoom. De gegevens 3uggereren echter dat GICA positieve cellen, een agressiever gearag vertonen dan GICA negatieve cellen. Dit gegeven is uit biologisch oogpunt interessant. De relevantie ervan voor de klinisch pathologische praktijk is chter beperkt vawege de heterageniteit, die ten anzien van de GICA expressle in een groot deel van de colorectale carcinomen gevonaen wordt.

Hoofdstuk $v$ vermeldt een onderzoek waruit nog duidelijker blijkt dat de fenotypische heterogeniteit van antigeen expressie de prognostische warde van het aantonen van weefselantigenen aarzienlijk beperkt. In dit onderzoek werden significante verbanden aangetoond tussen het expressilepatroon van secretoir component (SC) in colorectale tumoren enerajjas en de uitgebreidheid en de histologische differentiatlegrad van de tumor en de overlevingsuur van patienten anderzijas. Tumoren met uniforme SC positiviteit werden in significant hogere mate angetroffen in combinatie met een beperkte uitbreiding en een goede differentiatiegraad. SC positieve tumoren waren bovendien geassocieerd met een significant langere overleving. Tumoren zonder $5 C$ expressie darentegen werden meer gevonder in de groep van carcinomen met uitbreiding door de gehele darmwand en een slechte differentiatiegraad. Deze tumoren gingen bovendien gepaard met een kortere levensduur van patienten. Bij carcinomen met een focal, heterogeen SC expressiepatroon kon echter geen enkele relatie met stadium van uitbreiding van de tumor en histologische differentiatiegraad worden aangetoond. Het significante verschil in overleving tussen patienten met sC positieve en die met $S C$ negatieve tumoren verdween bovendien, indien de focal positieve tumoren bij de analyse betrokken werden. Uit deze bevindingen mag geconcludeerd worden, dat de SC expressie status in colorectale tumoren van prognostische betekenis is. Omdat zoveel tumoren een heterogene SC expressie vertonen, is de praktische betekenis ervan echter beperkt. De SC expressie status lijkt een bijdrage te kunnen leveren bij het stellen van de prognose van patienten met goed en matig gedifferentieerde colorectal carcimomen, doch blijft als enige prognostische parameter ondergeschikt an het stadium van uitbreiding van de tumor.

Hoofdstuk VI stelt het fenomeen van de antigene heterogeniteit zelf aan de orde. Met behulp van een reeks antilichamen, die reageren met colorectal carcinoomweefsel werd de mate van antigene heterogeniteit in primaire colorectale carcimomen bepald. Tevens werd onderzocht of er verschillen in het antigeen expressieprofiel tussen primaire tumoren en metastasen bestaan. Lynfogene metastasen bleken even divers en heterogeen van antigene samenstelling als de primaire tumoren. Mij vonden echter aanwijzingen at bij hematogene metastasen een verlies van antigenen kan optreden. De impli- 
caties van deze bevindingen in verband met immunotargeting procedures worden eveneens in dit hoofdstuk besproken.

Hoofdstuk VII (epiloog) geeft een beschrijving van de perspectieven en beperkingen van het onderzoek naar de antigeen expressie in weefsel. in het kader van onze oncerzoeksresultaken. Daarnaast worden wegen aangegeven om de beperkingen te verminderen, die ontstaan door de twee voornoemde factoren: het ontbreken wam antigenen specificiek voor colorectal (carcinoom) weefsel en de heterogeniteit van de antigeen expressie.

Tenslotte wordt aandacht besteed aan de warde, die het bepalen van weefselantigenen zou kunnen hebben voor een aan celorigine gerelateerde classificatie van colorectale carcinomen. 
In this thesis some pexspectives and limitations of the study on antigen expression in tissue are considered in the context of a series of immunohistachemica 1 imvestigations on colorectal carcinoma tissue.

Chapter I provides a review of the relevant data from the literature on antigen expression in colorectal cancer tissue and sketches the design of our experiments. From the data in the literature it can be concluded, that detection of antigen expresion at the tissue level may be of value in the characerization and classification of primary tumours and their metastases (diaqnosis). In addition it may be expected, that the presence or absence of certain antigens in tumours can be indicative for their behaviour in patients (proanosis). The lack of antigens specific for colorectal (cancer) tissue, as well as the phenomenon of antigenic heterogeneity in most tumours, however, pose severe Iimitations to this potential diagnostic and prognostic value.

Chapter II presents the results of a study on the specificity of Gastro-Intestinal-Cancer-Associated antigen (GICA). According to the data in the literature, mainly based on serological studies and exploration of cell-lines in culture, expression of this antigen was claimed to be restricted to neoplastic and fetal tissue of digestive tract origin. Our immunocytochemical exploration of GICA expression on a variety of tissue specimens, however, provided evidence that the antigen occurs in glandular epithelia and carcinomas of other than digestive tract derivation. The study therefore, underscores the importance of extensive immunocytochemical analysis on fresh and fixed tissues in the exploration of antigen-specificity.

Chapter III deals with a study to correlate the GICA expression status in colorectal carcinomas with clinicopathological variables of prognostic importance, such as the stage of tumour extension and the histological grade. Since the GICA expression status did not appear to be associated with these wariables, it shoul be expected, that the prognostic value of determination of GICA expression is very limited.

This expectation is further confirmed by the study of Chapter IV, in which no significant correlation between the GICA expression pattern and the survival of colorectal cancer patients could be established. The suggestion from our data, that GICA expressing cells might show a more aggressive behaviour than GICA negative cells, is of interest from the biological point of wiew. The relevance of this phenomenon in clinicopathological practice, however, appears to be 1 imited due to the occurcence of a substantial propor- 
tion of colorectal carcinomas with a heterogeneous Grca expression pattern.

That the phenotypic of heterogeneity in antigen expression considerably interferes with the potential prognostic value of tissue antigen expression, is even more explicitiy stressed in the study described in chapter V. In this study significant associations could be demonstrated between the type of expression of secretory component (SC) in colorectal carcinomas on the one hand and the stage of tumour extension, the histological grade and the survival time in patients at the other hand. Uniformly SC positive tumours were significantly more often observed in the group of low-stage and low-grade carcinomas and in addition showed significantly longer survival periods in patients. In contrast, tumours without SC expression were associated with high-stage and high-grade carcinomas and demonstrated shorter survival periods in patients. Tumours with a focal, heterogeneous $\mathrm{SC}$ expression pattern, however, Eailed to show any correlation with stage and with grade, whereas their inclusion in the analysis of survival data obscured the significant difference in patient survival between SC positive and SC negative tumours. Although from these observations it can be concluded that the $\mathrm{SC}$ expression status is of prognostic significance in colorectal carcinomas, the occurrence of a substantial proportion of tumours with a heterogeneous SC expression pattern attenuates its practical value. SC expression as such appears to be a valuable prognostic indicator in patients with well- or moderately differentiated colorectal. carcinomas, but as independent prognostic parameter remains inferior to that of the stage of tumour extension.

In Chapter VI the phenomenon of antigenic heterogeneity is highlighted. Through the application of a series of colorectal cancer-reactive antibodies the extent of antigenic heterogeneity in primary colorectal carcinomas was determined. At the same time the question, whether metastases due to the clonal selection purportedly occurring in metastasis might demonstrate a more restricted or different antigen expression profile, was investigated. Lymphnode metastases and primary tumours appeared to be equally diverse and heterogeneous of antigenic composition, whereas hematogenous metastases might show a tendency to loose expression of some antigens. The implications of heterogeneity in antigen expression and possible loss of antigens in regard to limunotargeting procedures are also discussed in this chapter.

In Chapter VII (the epilogue) the perspectives and limita tions of the study of tissue antigen expression are reviewed in the context of the results obtained in our investigations. Ways which might alleviate the impediments formed by the (current?) lack of colorectal (cancer)tissue-specific antigens and the occurrence of antigenic heterogeneity are indicated. Finally the potential value of tissue antigen detection for a cell-origin-related classification of colorectal carcinomas is considered. 
That the accomplishment of a study correlating pathologica 1 with clinical data would have been impossible for a pathologist without the active support of a clinician, is evident. Therefore, first of all, I ish to express my gratitute to Theo Wiggers, who not anly took care of the collection and computerization of the patient data, but also enthousiastically cooperated in the planning and execution of this study".

In respect of the design, the frame and the wording of this thesis $\mathbb{I}$ owe a great deal to professor Bosman. Without his sympathetic, critical and accurate appoach the study would not have had the loglcal form and the standard in which it is now presented.

I am very much indebted to professor swaen, who also took a berevolent part in the realization of this study and whose atcitude as my teacher in pathology has guaranteed my education as a pathologist in an atmosphere of fatherly support.

The cole of professor Greep as a critical reviewer of the manuscript and as the man whose well-organized department could take the lead in the effectuation of the colorectal trial, has been indispensable.

The willingness of professor Isaacson, who, as a matter of Eact, laid the foundation of this study by arousing my interest in intestinal pathology as well as SC, to attend the ceremony, obliges me very much.

Dr. Jo Hilgers generated my interest in monoclonal antibodies, provided me with means to materialize this interest and was actively involved in the realization of the KWF project, which partly formed the financial basis of this thesis.

During the past three years Margriet Pijls and Birgit Engelen have devoted much of their time and energy to stain the mumerous tissue sections with many different antibodies and also to take care of the filing and administration of the slides, gracefully challenging but enduring my not throughout consistent demands.

The same applies to claire Bollen-prevot, Mariamne RikersLaarmans, Elly Kerssemeekers-van den Essen. Marcia steegmans-van puyenbroek, Michele Reynders and Cor Evers, who were invalved in the preparation of the manuscript, figures and microphotographs.

In addition, many more persons obviously deserve attention as contributors to this venture. Of these I would bring out Cees Verstijnen and Peter Moerkerk, who were of invaluable help in the execution of the KWF project, Bert Schutte, who added flow cytometrical as well as substantial dimensions to the study and carel Thijs, who spent his first months as a medical doctor on the problem of classification and 
antigen expression in colorectal cancers to my benefit. Finally, I would like to acknowledge my collegues in the department for allowing me to spend much of my time to the investigations in a cordial atmosphere and the pathologists from the hospitals participating in the colorectal trial for their kindly providing part of the material for this study 
1946

$1958-1964$

1964-1972

1972

$1973-1975$

$1975-1976$

$1977-1980$

1980

$1981=$
Born in Groningen

Gymnasium B, Groningen

Medical School, State University Groningen

Assistantship in surgery and Gynecology/ Obstetrics, Scheper ziekenhuis, Emmen

Medical Superintendent, General Bospital Iquita, Oron, SES, Nigeria

Resident in Gynecology/obstetrics, Teaching Hospital. State University Groningen (head: Prof.dr.H.J. Huisjes)

Resident in Pathology, Hospital St. Annadal, Maastricht (head: Prof.dr. G.J.V. Swaen)

Stay at the Department of Pathology, General Hospital Southampton, England (Head: Prof.dr. D.H. Wright)

Staff pathologist state University of Limburg, Hospital St. Annadal, Maastricht. 